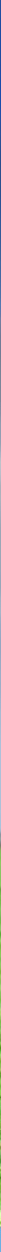

\title{
Klimaatslimme melkveehouderij
}

Een routekaart voor implementatie van mitigatie- en adaptatiemaatregelen

Marion de Vries, Idse Hoving, Jantine van Middelkoop, Jan ten Napel, Rommie van der Weide,

Rapport 1131

Jan Verhagen, Theun Vellinga

\section{WAGENINGEN}

UNIVERSITY \& RESEARᄃH 



\section{Klimaatslimme melkveehouderij1}

Een routekaart voor implementatie van mitigatie- en adaptatiemaatregelen

Marion de Vries ${ }^{1}$, Idse Hoving ${ }^{1}$, Jantine van Middelkoop ${ }^{1}$, Jan ten Napel ${ }^{1}$, Rommie van der Weide ${ }^{2}$, Jan Verhagen ${ }^{2}$, Theun Vellinga ${ }^{1}$

1 Wageningen Livestock Research

2 Wageningen Plant Research

Dit onderzoek is uitgevoerd door Wageningen Livestock Research, in opdracht van en gefinancierd door het Melkveefonds

Wageningen Livestock Research

Wageningen, november 2018

Rapport 1131 
De Vries, M., I.E. Hoving, J.C. van Middelkoop, J. ten Napel, R.Y. van der Weide, J. Verhagen, T.V. Vellinga, 2018. Klimaatslimme melkveehouderij. Een routekaart voor implementatie van mitigatie- en adaptatiemaatregelen. Wageningen Livestock Research rapport 1131.

Het doel van deze studie was om in kaart te brengen voor welke opgave de Nederlandse melkveehouderijsector staat met betrekking tot klimaatmitigatie en -adaptatie, en bij te dragen aan oplossingsrichtingen in de vorm van een routekaart voor implementatie van klimaatslimme maatregelen op de korte- en middellange termijn $(2030,2050)$. Wat betreft mitigatie moet de sector voldoen aan beleidsdoelstellingen voor reductie van broeikasgasemissies in sectoraal, nationaal en Europees beleid. Wat betreft adaptatie wordt enerzijds verwacht dat de melkveehouderij kan profiteren van hogere temperaturen en $\mathrm{CO} 2$ concentraties, maar anderzijds kan een toename in weersextremen en dierlijke/plantaardige ziekten en plagen dit effect afzwakken of teniet doen. De routekaart betreft een gefaseerde implementatie van mitigatie- en adaptatiemaatregelen, waarbij rekening wordt gehouden met effectiviteit, kosten, afwentelingen en praktijkrijpheid van maatregelen.

The aim of this study was to describe the challenges faced by the Dutch dairy sector in terms of climate change mitigation and adaptation, and to show possible pathways for implementation of mitigation and adaptation options towards 2030 and 2050. With regard to mitigation, the dairy sector has to comply with targets for mitigation of greenhouse gas emissions in sectoral, national and European legislation. With regard to adaptation, dairy farms are expected to benefit from increasing temperatures and $\mathrm{CO} 2$ concentrations, but this may be counteracted by increases in extreme weather events and animal and plant diseases and plagues. A roadmap is shown with phased implementation of mitigation- and adaptation options, based on their effectiveness, costs, readiness for practical implementation, and interaction with other aspects of sustainability.

Dit rapport is gratis te downloaden op https://doi.org/10.18174/463803 of op www.wur.nl/livestock-research (onder Wageningen Livestock Research publicaties).

(C) 2018 Wageningen Livestock Research

Postbus 338, 6700 AH Wageningen, T 03174839 53, E info.livestockresearch@wur.nl, www.wur.nl/livestock-research. Wageningen Livestock Research is onderdeel van Wageningen University \& Research.

Wageningen Livestock Research aanvaardt geen aansprakelijkheid voor eventuele schade voortvloeiend uit het gebruik van de resultaten van dit onderzoek of de toepassing van de adviezen.

Alle rechten voorbehouden. Niets uit deze uitgave mag worden vermenigvuldigd en/of openbaar gemaakt worden door middel van druk, fotokopie, microfilm of op welke wijze dan ook zonder voorafgaande toestemming van de uitgever of auteur.

Wageningen Livestock Research is NEN-EN-ISO 9001:2015 gecertificeerd.

Op al onze onderzoeksopdrachten zijn de Algemene Voorwaarden van de Animal Sciences Group van toepassing. Deze zijn gedeponeerd bij de Arrondissementsrechtbank Zwolle. 


\section{Inhoud}

$\begin{array}{ll}\text { Samenvatting } & 5\end{array}$

1

$\begin{array}{ll}\text { Inleiding } & 9\end{array}$

1.1 Achtergrond $\quad 9$

$\begin{array}{lll}1.2 \text { Doel } & 10\end{array}$

$\begin{array}{lll}1.3 & \text { Werkwijze } & 10\end{array}$

1.3.1 Literatuurverkenning en raadpleging van experts $\quad 11$

1.3.2 Stakeholder workshops 11

1.3.3 Ontwikkeling van een routekaart 11

1.4 Opbouw van het rapport $\quad 12$

$2 \quad$ Mitigatie

$2.1 \quad$ Broeikasgasemissies melkveehouderij 13

2.2 Klimaatbeleid 16

$\begin{array}{lll}2.3 & \text { Mitigatiemaatregelen } & 18\end{array}$

$\begin{array}{lll}2.4 & \text { Interactie met andere duurzaamheidsthema's } & 26\end{array}$

3

$\begin{array}{ll}\text { Adaptatie } & 29\end{array}$

$\begin{array}{lll}3.1 & \text { Introductie } & 29\end{array}$

3.2 Gevolgen van klimaatverandering voor de melkveehouderij 30

3.2.1 Gras en gewas $\quad 32$

3.2.2 Gewasbescherming $\quad 35$

3.2.3 Diergezondheid en welzijn 37

$\begin{array}{ll}3.2 .4 \text { Waterbeheer } & 39\end{array}$

$\begin{array}{lll}3.3 & \text { Adaptatiemaatregelen } & 41\end{array}$

3.3.1 Gras en gewas $\quad 43$

3.3.2 Gewasbescherming $\quad 44$

3.3.3 Diergezondheid en dierenwelzijn $\quad 46$

$\begin{array}{ll}\text { 3.3.4 Waterbeheer } & 48\end{array}$

$4 \quad$ Routekaart $r \mathbf{5 2}$

$4.1 \quad$ Introductie $\quad 52$

4.2 Autonome ontwikkeling: wat gebeurt er als de sector niets doet? 52

4.3 Routekaart voor inpassing van klimaatslimme maatregelen 53

4.3.1 Flexibel plannen $\quad 54$

4.3.2 Mitigatie $\quad 54$

4.3.3 Adaptatie $\quad 59$

4.4 Handelingsperspectieven $\quad 62$

$\begin{array}{ll}4.4 .1 \text { Sector } & 62\end{array}$

4.4.2 Beleid 64

$\begin{array}{ll}4.4 .3 \text { Onderzoek } & 64\end{array}$

$5 \quad$ Discussie \& conclusie $\quad 65$

$\begin{array}{ll}\text { Literatuur } & 68\end{array}$

$\begin{array}{lll}\text { Bijlage } 1 & \text { Interactietabel mitigatiemaatregelen } & 74\end{array}$

Bijlage 2 Gewasbeschermings-problematiek en anticiperende maatregelen $\begin{array}{ll}\text { per gewas } & 76\end{array}$ 
Bijlage 3 Verslag kennissessie mitigatieperspectieven melkveehouderij 79

Bijlage 4 Verslag workshop klimaatbestendige melkveehouderij 83

Bijlage 5 Aanbevelingen voor onderzoek per discipline 


\title{
Samenvatting
}

\author{
Klimaatverandering zorgt in toenemende mate voor veranderende omstandigheden voor de \\ Nederlandse melkveehouderij. Enerzijds zorgen klimaatdoelstellingen in Nederlands en \\ Europees beleid ervoor dat de sector de uitstoot van broeikasgassen fors moet terugdringen \\ ('klimaatmitigatie'). Anderzijds heeft klimaatverandering effect op de fysische en \\ sociaaleconomische productieomgeving van de melkveehouderij, en is het noodzakelijk om \\ hier tijdig op in te spelen om kwetsbaarheid te verminderen en kansen te benutten \\ ('klimaatadaptatie'). Het doel van deze studie was om in kaart te brengen voor welke \\ opgave de melkveehouderij staat met betrekking tot klimaatmitigatie en -adaptatie, en bij \\ te dragen aan oplossingsrichtingen in de vorm van een routekaart voor implementatie van \\ klimaatslimme maatregelen op de korte- en middellange termijn $(2030,2050)^{1}$.
}

\section{Werkwijze}

Voor het in kaart brengen van de opgave omtrent klimaatmitigatie en -adaptatie en klimaatslimme oplossingsrichtingen is gebruik gemaakt van literatuurverkenning, raadpleging van experts en stakeholder workshops. Voor de ontwikkeling van de routekaart zijn mitigatie- en adaptatiemaatregelen door auteurs van dit rapport geprioriteerd en uitgezet in de tijd op basis van effectiviteit, kosten, praktijkrijpheid en afwentelingen naar andere duurzaamheidsthema's.

\section{Wat is een 'klimaatslimme' melkveehouderij?}

In een klimaatslimme melkveehouderij wordt de uitstoot van broeikasgassen gereduceerd (mitigatie) en de weerbaarheid voor gevolgen van klimaatverandering versterkt (adaptatie), terwijl gelijktijdig een duurzame productie en inkomen wordt gerealiseerd (FAO, 2013). De ontwikkeling naar een klimaatslimme melkveehouderij moet plaatsvinden op een integraal duurzame manier, wat betekent dat het niet ten koste mag te gaan van andere duurzaamheidsthema's in de melkveehouderij.

Wat is de opgave voor klimaatmitigatie en -adaptatie?

Wat betreft klimaatmitigatie heeft de Nederlandse melkveehouderijsector te maken met verschillende reductiedoelstellingen in sectoraal, nationaal en Europees beleid. Op sectorniveau heeft de Duurzame Zuivel Keten (DZK) ten doel gesteld broeikasgasemissies uit de zuivelketen met $20 \%$ te reduceren in 2020 (t.o.v. 1990) en vanaf het jaar 2011 emissies niet meer te laten stijgen. Op nationaal niveau is ten doel gesteld de totale uitstoot van broeikasgassen in Nederland terug te dringen met $49 \%$ in 2030 en $95 \%$ in 2050, en volgens Europese beleidsdoelen moeten non- ETS sectoren in Nederland (waaronder de landbouw valt) de uitstoot met 36\% verminderen in 2030 (t.o.v. 2005) en voor de gehele EU 80-95\% reductie in 2050 (t.o.v. 1990; Effort Sharing Regulation). De concrete opgave voor de zuivelsector en verantwoordelijke partijen moeten nog worden vastgesteld.

Wat betreft de opgave voor klimaatadaptatie laten klimaatscenario's zien dat in Nederland de gemiddelde temperatuur en $\mathrm{CO} 2$ concentraties in de lucht zullen stijgen, en neerslagpatronen veranderen. Daarnaast neemt de kans op weersextremen toe, zoals langdurige droogte, extreme regenbuien, hagel en onweer, en meer hittedagen in de zomer. Door zeespiegelstijging zal verzilting een toenemend probleem worden. Het voorspellen van de gevolgen van klimaatverandering voor de melkveehouderij is complex, onder andere vanwege een grote mate van onzekerheid omtrent klimaatscenario's. De verwachting is dat klimaatverandering gevolgen heeft voor de volgende 6 thema's: gras- en gewasproductie; ziekten en plagen in planten en dieren; diergezondheid, productiviteit, en -welzijn; prijzen van grondstoffen en zuivel; productiemiddelen (bijv. land, water, machines, gebouwen); en bedrijfsvoering (bijv. beweiding, timing maaien, voerregimes). In deze studie zijn de eerste 3 thema's verder uitgewerkt. Door hogere temperaturen, een langer groeiseizoen en hogere $\mathrm{CO} 2$ concentraties enerzijds, en weersextremen anderzijds, kunnen effecten zowel positief

\footnotetext{
${ }^{1}$ Deze studie had niet ten doel een mitigatiepotentieel op sectorniveau te kwantificeren. Er zijn andere initiatieven waarin het absolute reductiepotentieel en kosteneffectiviteit van mitigatiemaatregelen wordt berekend. De huidige studie kan een strategische inzet van maatregelen ondersteunen.
} 
als negatief uitvallen. Voorbeelden van positieve effecten zijn de verwachte toename in grasproductie, een hogere water- en (winter) stikstofefficiëntie van gewassen, en kansen voor nieuwe gewassen. Negatieve effecten zijn bijvoorbeeld een lagere productie en verteerbaarheid van gras bij langdurige droogte, en het verlies aan groeidagen, uitspoeling van nutriënten en minder mogelijkheden voor berijding en beweiding bij extreme neerslag. Door klimaatverandering worden daarnaast meer problemen verwacht met schimmelziekten, virussen, onkruiden en plaaginsecten in gewassen. Ook kunnen risico's omtrent de gezondheid en welzijn van melkvee toenemen door een toename in de verspreiding en overdracht van infectieuze ziekteverwekkers, endo- en ectoparasieten, en niet infectieuze aantastingen zoals hittestress en metabole stress.

\section{Autonome ontwikkeling: wat gebeurt er als de sector niets doet?}

Verwacht wordt dat onvoldoende emissiereductie wordt behaald wanneer huidige trends in het melkproductievolume en inspanningen om emissies te reduceren worden voortgezet. Dankzij de stijging van het totale melkvolume na afschaffing van het melkquotum en een vrijwel gelijkblijvende emissie intensiteit (broeikasgasemissies per $\mathrm{kg}$ melk), is het totale emissievolume in de afgelopen jaren toegenomen. Een reductie van de emissie-intensiteit is in het verleden met name behaald door efficiëntieverbeteringen, en ook in de huidige discussie in de praktijk ligt er veel nadruk op maatregelen gericht op efficiëntieverbeteringen en hernieuwbare energie. Wanneer niet tijdig wordt gestart met additionele maatregelen zullen huidige inspanningen bij een gelijkblijvend of stijgend melkvolume onvoldoende zijn om de benodigde emissiereducties in 2030 en 2050 te realiseren.

De verwachting is dat de stijging van de omgevingstemperatuur en de $\mathrm{CO} 2$ concentraties in de lucht een positief effect hebben op het toekomstig bruto bedrijfsresultaat, maar ook dat weersextremen dit positieve effect kunnen afzwakken of teniet doen. Daarnaast hebben andere factoren, zoals technologie-, beleid- en marktontwikkeling, waarschijnlijk meer invloed op de ontwikkeling en technische prestaties van bedrijfssystemen dan weersveranderingen. Omtrent klimaat-, economischeen sociaalmaatschappelijke scenario's is echter veel onzeker. Ook de kansen op uitbraken of versnelde verspreiding van dierlijke of plantaardige ziekten en plagen zijn lastig te voorspellen. Daarnaast zijn effecten sterk locatie afhankelijk. Verwacht wordt dat de sector zelf goed zal inspelen op de kansen die klimaatverandering biedt, maar dat extra inspanning nodig is om de sector weerbaarder te maken tegen negatieve gevolgen van klimaatverandering, zijnde een vorm van risicomanagement.

\section{Een routekaart voor implementatie van klimaatslimme maatregelen}

In dit rapport zijn een groot aantal maatregelen beschreven voor het reduceren van broeikasgasemissies en het verbeteren van de klimaatbestendigheid van melkveebedrijven. Maatregelen kunnen niet allemaal direct worden ingezet, en dat is ook niet verstandig. Prioritering en fasering van de inpassing van maatregelen is van belang voor een strategische en integrale aanpak van de mitigatie- en adaptatieopgave. In dit rapport is een routekaart ontwikkeld voor inpassing van mitigatie- en adaptatiemaatregelen op de korte (2030) en middellange (2050) termijn. De routekaart betreft een gefaseerde inzet van klimaatslimme maatregelen, waarbij rekening wordt gehouden met kosten, afwentelingen en praktijkrijpheid van maatregelen. Hierbij wordt een flexibele planning gehanteerd, wat betekent dat actief wordt geanticipeerd op de noodzaak om de voorkeursroute te verleggen wanneer onvoldoende resultaat wordt behaald of veranderende omstandigheden daarom vragen, zoals toekomstig beleid, sociaal-maatschappelijke en economische ontwikkelingen, of nieuwe technologieën.

De routekaart voor mitigatie ziet er als volgt uit:

- Op de korte termijn (2030) worden maatregelen ingezet die praktijkrijp zijn, geen of lage kosten hebben, en geen (of nauwelijks) afwentelingen naar andere duurzaamheidsthema's ('laag hangend fruit'): (i) Reductie methaan en lachgas emissies (bijdrage non-ETS) via maatregelen in mestmanagement, gewasproductie, veevoeding en diermanagement (o.a. snelle verwijdering mest uit de stal, methaanoxidatie van emissies uit mestopslag, meer gebruik van grasklaver, aanpassingen krachtvoer, verbeteren diergezondheid); (ii) Reductie koolstofdioxide emissies (bijdrage ETS) door gebruik en productie van hernieuwbare energie; (iii) Koolstofvastlegging (bijdrage landgebruik sector) via diverse maatregelen die het organische stof gehalte in de bodem verhogen (o.a. minder kerende grondbewerking, verbeterde vruchtwisseling) en verminderen van veenafbraak (peilverhoging i.c.m. onderwaterdrainage). 
- Op middellange termijn (2050) worden maatregelen ingezet die op dit moment nog niet praktijkrijp of erg kostbaar zijn. Voor zover mogelijk worden maatregelen met afwentelingen vermeden. Mogelijk komen andere, nieuwe technieken in de tussentijd beschikbaar. Hiermee wordt de uitstoot van methaan en lachgas verder teruggedrongen, bijv. door het benutten van de hogere omgevingstemperatuur en $\mathrm{CO} 2$ concentraties voor verbeterde en efficiëntere gewasproductie, fokken op dieren met lagere enterische methaanemissies, en een bijdrage te leveren aan een hoger organische stof gehalte in akkerbouw (o.a. wisselbouw met gras). Richting 2050 zal de sector toewerken naar haar rol in een klimaat-slim (productie)

landschap/voedselsysteem waarin afwentelingen naar andere sectoren worden voorkomen en mogelijkheden voor andere rollen naast melkproducent worden ingevuld, zoals benutting van reststromen, productie van hernieuwbare energie, biomassa voor de biobased economy, dierlijke mest, waterbuffering en -berging, natuurbeheer, etc.

Omdat bij adaptatie de keuze van maatregelen meer afhankelijk is van de locatie en het bedrijfstype in combinatie met specifieke klimaatrisico's, is een routekaart uitgewerkt voor bedrijven op droogtegevoelige gronden in relatie tot het toenemende risico op langdurige droogte:

- Op de korte termijn gaat de voorkeur uit naar waterconservering door het vasthouden van oppervlaktewater (d.m.v. stuwen, daar waar mogelijk) en van water in de bodem door het verbeteren van de bodemstructuur en het toepassen van peilgestuurde drainage. Waar akkerbouwmatige teelten nodig zijn om in de voerbehoefte te voorzien draagt het toepassen van nauwe vruchtwisseling van gras met akkerbouwgewassen bij aan een betere bodemconditie en een hoger organische stofgehalte van bouwland. Investeren in beregenen heeft niet de voorkeur.

- Op middellange termijn, wanneer het risico op langdurige droogte verder toeneemt, kan worden gekozen voor mengteelten en soortenrijk grasland, en het telen van droogteresistente gewassen. In $z$ 'n algemeenheid verdient het aanbeveling om te kunnen beschikken over voldoende ruwvoervoorraad.

\section{Handelingsperspectieven}

In de sector moet op korte termijn intensief aandacht worden besteed aan bewustwording en educatie van melkveehouders, beloningsstructuren, en ontwikkeling van instrumenten voor benchmarking in de praktijk. Maatregelen moeten worden getest in pilots in diverse bedrijfstypen en locaties, uitmondend in een portfolio van klimaatslimme ontwikkelmogelijkheden voor diverse bedrijfstypen op korte en langere termijn, met minimale afwentelingen naar andere duurzaamheidsthema's. Op sectorniveau moet geanticipeerd worden op de eventuele noodzaak tot sturing van het productievolume. Het emissievolume is een product van emissie-intensiteit en productievolume. Als de reductie in intensiteit niet voldoende is om reductiedoelstellingen te behalen zullen aanpassingen in het productievolume nodig zijn om het totale emissievolume te reduceren. Dat kan ook aanleiding zijn om te werken aan een herstructurering/-allocatie van de melkveehouderij in Nederland. Daarnaast zijn er maatregelen die een meer sectorbrede aanpak vergen, waaronder veredeling, fokkerij, beheersing van (dierlijke/plantaardige) ziekten en plagen, en signaleren van klimaatrisico's en kansen. De sector moet in overleg met andere partijen voor nieuwe vormen van samenwerken, risicodeling, ketenversterking, en de rol van de melkveehouderij in het versterken van regionale veerkracht. De overheid kan het treffen van maatregelen stimuleren door voorlichting, organiseren van benchmarking, convenanten, en het (gezamenlijk) creëren van economische prikkels en/of verplichtingen. De routekaart in dit rapport kan als uitgangspunt dienen voor een gedetailleerd uitvoeringsprogramma voor mitigatie en adaptatie in de melkveehouderijsector. 


\section{$1 \quad$ Inleiding}

\section{$1.1 \quad$ Achtergrond}

Klimaatverandering zorgt in toenemende mate voor veranderende omstandigheden voor de Nederlandse melkveehouderij. Enerzijds zorgen doelstellingen in internationaal en Nederlands beleid ervoor dat de sector de uitstoot van broeikasgassen fors moet terugdringen ('klimaatmitigatie'). Anderzijds heeft klimaatverandering effect op de fysische en sociaaleconomische productieomgeving van de melkveehouderij, en is het noodzakelijk om hier tijdig op in te spelen om kwetsbaarheid te verminderen en kansen te benutten ('klimaatadaptatie').

\section{Klimaatmitigatie: opgave voor verminderen van broeikasgasemissies}

De Nederlandse melkveehouderij draagt bij aan klimaatverandering en staat daarmee voor de uitdaging om broeikasgasemissies verder terug te dringen. Reductiedoelstellingen in Nederlands en Europees beleid vloeien voort uit het klimaatakkoord van Parijs (2015), en zijn gebaseerd op reductie van totale emissievolumes. De Duurzame Zuivelketen (DZK) heeft ten doel gesteld om in 2020 broeikasgasemissies met $20 \%$ te reduceren t.o.v. 1990, en om vanaf het jaar 2011 netto emissievolumes vanuit de sector niet meer te laten stijgen. Op nationaal niveau zijn reductiedoelstellingen voor Nederland vastgelegd in de Klimaatwet (2018), wat inhoudt dat in 2050 broeikasgasemissies met 95\% moeten zijn gereduceerd t.o.v. 1990. Als gevolg van de Europese Effort Sharing Regulation (ESR) moet Nederland tussen 2005 en 2030 de totale emissies uit non- ETS sectoren, waar landbouw onder valt, met $36 \%$ reduceren. Ondanks dat nog niet bekend is welke bijdrage de melkveehouderij hierin moet leveren ${ }^{2}$, is wel duidelijk dat de opgave fors is, o.a. doordat de sector reeds een lage emissie per $\mathrm{kg}$ melk ('emissie intensiteit') kent. Een verlaging van het totale emissievolume door de sector als geheel kan worden gerealiseerd door een verdere verlaging van de emissie per $\mathrm{kg}$ melk (emissie intensiteit), en/of een verlaging van het totale productievolume.

\section{Klimaatadaptatie: opgave voor het verbeteren van de klimaatbestendigheid} Klimaatscenario's van het KNMI (2014) laten zien dat de gemiddelde temperatuur in Nederland zal stijgen en de gemiddelde neerslag zal toenemen. Winters worden zachter met meer neerslag, en er is meer kans op weersextremen, zoals langere periodes van droogte, extreme regenbuien, hagel en onweer, en meer hittedagen in de zomer. Door zeespiegelstijging zal verzilting een toenemend probleem worden. Verschillen tussen de scenario's laten ook zien dat nog veel onzeker is. Veranderingen in het klimaat kunnen zowel positieve als negatieve gevolgen hebben voor de melkveehouderijsector, met name voor de voervoorziening wegens effecten op gras- en gewasproductie, materieel en gebouwen, en potentieel ook voor diergezondheid en welzijn van melkvee. Het anticiperen op klimaatverandering op langere termijn lijkt voor de sector vooralsnog geen prioriteit te hebben, terwijl reageren op korte termijn variaties wel goed ingebed is in de sector (Schaap et al., 2014). De sector kan er haar voordeel mee doen om klimaatrisico's en kansen tijdig te signaleren, zodat risico's kunnen worden beperkt en kansen worden gegrepen.

\section{Klimaatslimme melkveehouderij}

In een klimaatslimme melkveehouderij wordt de uitstoot van broeikasgassen gereduceerd (mitigatie) en de kwetsbaarheid voor klimaatverandering verminderd (adaptatie), terwijl gelijktijdig een duurzame productie en inkomen wordt gerealiseerd (FAO, 2013). De ontwikkeling naar een klimaatslimme melkveehouderij moet plaatsvinden op een integraal duurzame manier, wat betekent dat het niet ten koste mag te gaan van de rendabiliteit en van prestaties op het gebied van andere belangrijke duurzaamheidsthema's.

\footnotetext{
2 De emissieopgave voor de zuivelsector was ten tijde van de uitvoering van deze studie nog niet vastgesteld.
} 


\section{Routekaart voor implementatie van klimaatslimme maatregelen}

Wanneer de sector niet tijdig inspeelt op toekomstige klimaatdoelen en effecten van

klimaatverandering kunnen de hoge efficiëntie en productiviteit van de melkveehouderij in Nederland onder druk komen te staan. Voor zowel bestuurders als ondernemers in de sector is het daarom van groot belang de risico's van klimaatverandering te kennen en daar rekening mee te gaan houden. Met name de planning van adaptatiemaatregelen is complex en behoeft een lange termijn perspectief.

In deze studie is een routekaart ontwikkeld gericht op de implementatie van mitigatie- en adaptatiemaatregelen op de korte (2030) en middellange (2050) termijn. De routekaart betreft een gefaseerde, flexibele planning voor het inpassen van klimaatslimme maatregelen, waarbij rekening wordt gehouden met kosten, afwentelingen en praktijkrijpheid van maatregelen. De routekaart wordt onderbouwd met een gedetailleerde beschrijving van de opgave voor de melkveehouderij en beschikbare mitigatie- en adaptatiemaatregelen, en een langetermijnvisie op klimaatslimme melkveehouderij.

De routekaart kan als uitgangspunt kan fungeren voor de ontwikkeling van een gedetailleerd uitvoeringsprogramma voor de sector. Daarin moet worden vastgesteld welke stappen ondernomen moeten worden om een klimaatslimme melkveehouderij te realiseren, zoals het vergroten van de bewustwording en kennis in de sector, ontwikkeling van klimaatslimme maatregelen in onderzoek en praktijk, benoemen van verantwoordelijkheden van betrokken partijen, monitoring en evaluatie, en procesbegeleiding.

\subsection{Doel}

Het doel van deze studie was het in kaart brengen van de opgave waar de melkveehouderij voor staat met betrekking tot klimaatmitigatie en -adaptatie, en een bijdrage te leveren aan oplossingsrichtingen in de vorm van een routekaart voor implementatie van klimaatslimme maatregelen op de korte- en middellange termijn $(2030,2050)$.

Dit doel is uitgesplitst naar 3 subdoelen:

1. Beschrijving van de opgave en oplossingsrichtingen voor ontwikkeling van een klimaatslimme melkveehouderij, met betrekking tot klimaatmitigatie en -adaptatie, rekening houdend met andere duurzaamheidsthema's.

2. Ontwikkeling van een routekaart voor implementatie van maatregelen op de korte (2030) en middellange termijn (2050), inclusief een langetermijnvisie op klimaatslimme melkveehouderij, fasering van mitigatie- en adaptatiemaatregelen, handelingsperspectieven, en kennisbehoeften.

3. Mobiliseren van actoren om het perspectief te vergroten dat het proces en de maatregelen die in de routekaart worden voorgesteld gecontinueerd worden.

Dit onderzoek had niet ten doel een mitigatiepotentieel op sectorniveau te kwantificeren. Er zijn andere initiatieven waarin het absolute reductiepotentieel en kosteneffectiviteit van verschillende maatregelenpakketten voor de Nederlandse zuivelsector wordt berekend. Onze studie kan een strategische inzet van dergelijke maatregelenpakketten ondersteunen.

\subsection{Werkwijze}

Het project 'Routekaart Klimaatslimme Melkveehouderij' is in 3 fases uitgevoerd:

1. Literatuurverkenning en raadpleging van experts, om de huidige kennis omtrent klimaatmitigatie en -adaptatie in kaart te brengen, en kennisgaten voor onderzoek en ontwikkeling te identificeren.

2. Stakeholder workshops om de sector te informeren over tussentijdse resultaten van het project, en een praktijkbijdrage te verkrijgen voor: i) de ontwikkeling van een visie voor een klimaatslimme melkveehouderij; ii) prioritering en fasering voor onderzoek en praktijk; en iii) 
actoren mobiliseren: vergroten van het perspectief dat de projecten en maatregelen die vanuit de routekaart worden ingezet ook gecontinueerd worden.

3. Ontwikkeling van de routekaart: een gefaseerde, flexibele planning voor het inpassen van klimaatslimme maatregelen, waarbij rekening wordt gehouden met kosten, afwentelingen en praktijkrijpheid van maatregelen.

\subsubsection{Literatuurverkenning en raadpleging van experts}

Op basis van bestaande literatuur en raadpleging van experts is voor klimaatmitigatie en -adaptatie de probleemstelling en potentiële oplossingsrichtingen in kaart gebracht:

- Voor mitigatie is de recente stand van zaken omtrent de emissiereductieopgave voor de zuivelsector beschreven en zijn mitigatiemaatregelen geïnventariseerd o.b.v. literatuur (o.a. Van den Pol et al., 2013; Ros and Daniëls, 2017) en expert opinie. Analysemethodes en aannames voor de verschillende literatuurresultaten zijn niet opgenomen in dit rapport en kunnen worden teruggevonden in de genoemde bronnen.

- Voor wat betreft klimaatadaptatie zijn op basis van bestaande literatuur en raadpleging van experts mogelijke gevolgen van klimaatverandering en potentiële oplossingsrichtingen (adaptatiemaatregelen) in kaart gebracht voor 3 thema's in de bedrijfsvoering: gras en gewas, gewasbescherming en diergezondheid en welzijn. Daarnaast is watervoorziening als transversaal thema meegenomen. Bedrijfsoverstijgende thema's, zoals effecten op internationale handel en elektriciteitsnetwerken (PBL, 2015b), en schade aan materieel en gebouwen zijn buiten beschouwing gelaten in dit rapport.

De resultaten zijn vastgelegd in een factsheet per thema, beschreven in Hoofdstuk 2 en 3 van dit rapport.

\subsubsection{Stakeholder workshops}

In het kader van dit project is een stakeholder workshop georganiseerd over Klimaatbestendige Melkveehouderij (april 2017, Beers) en een kennissessie over mitigatieperspectieven in de melkveehouderij (mei 2017, Wageningen). Het doel van de workshops was stakeholders te informeren over tussentijdse resultaten van het project, en een praktijkbijdrage te verkrijgen voor:

- Prioritering en fasering voor onderzoek en praktijk, inclusief het toetsen van de haalbaarheid van mitigatie en adaptatie maatregelen voortkomend uit de factsheets;

- Actoren mobiliseren: vergroten van het perspectief dat het proces en de maatregelen die in de routekaart worden voorgesteld gecontinueerd worden. De stakeholders hebben aangegeven bij welke onderdelen van de routekaart ze betrokken willen worden zodra die nader uitgewerkt worden.

\subsubsection{Ontwikkeling van een routekaart}

Voor klimaatmitigatie en -adaptatie zijn twee losstaande routekaarten uitgewerkt, waarin maatregelen worden geprioriteerd en uitgezet in de tijd. De routekaarten worden voorafgegaan door een schets van de autonome ontwikkeling van de melkveehouderij ("Wat gebeurt er als de sector niets doet?") en een toekomstvisie voor een klimaatslimme sector.

Omdat bij adaptatie kennis sterk is gefragmenteerd in deelthema's en de keuze van maatregelen sterk afhankelijk is van de locatie, het bedrijfstype, en het specifieke klimaatrisico, is bij de routekaart voor klimaatadaptatie gekozen voor case studie: hier is een routekaart uitgewerkt voor bedrijven op droogtegevoelige gronden (komklei, zand) in relatie tot het toenemende risico op langdurige droogte.

Prioritering van maatregelen

Om mitigatie- en adaptatiemaatregelen te prioriteren en uit te zetten in de tijd zijn maatregelen gescoord op basis van 4 criteria: 
- effectiviteit (voor mitigatie is alleen gekeken naar het technisch potentieel ( $\mathrm{kg} \mathrm{CO} 2 \mathrm{e} / \mathrm{kg}$ melk), en nog niet naar het aantal bedrijven dat de maatregel kan implementeren (ontsluitingspercentage)) ${ }^{3}$;

- interactie met andere duurzaamheidsthema's (energieverbruik, landgebruik, emissies naar lucht (ammoniak, broeikasgasemissies), emissies naar water (stikstof en fosfaat), bodemkwaliteit, landschap, biodiversiteit, klimaatbestendigheid, en 'overige' ecologische, economische of sociaalmaatschappelijke afwentelingen);

- kosteneffectiviteit (voor mitigatie is gekeken naar de kosten per kg reductie in broeikasgasemissies (in $€ / \mathrm{kg} \mathrm{CO} 2 \mathrm{e}$ ), voor adaptatie naar kosten en baten);

- praktijkrijpheid.

Voor iedere maatregel is een score toegekend op een schaal van -3 tot +3 , waarbij -3 een negatieve invloed betekende (afwenteling) en +3 een positieve invloed (synergie). Bij de interactie met duurzaamheidsthema's is alleen een score ingevuld wanneer met grote zekerheid een effect werd verwacht. Op basis van de scores zijn maatregelen vervolgens ingedeeld in 5 categorieën:

- laaghangend fruit (kosteneffectief, geen/nauwelijks afwentelingen, praktijkrijp)

- lage kosten (lage kosten (score -1), geen/nauwelijks afwentelingen, praktijkrijp)

- hoge kosten (hoge kosten (score -2 en -3), geen/nauwelijks afwentelingen, praktijkrijp)

- afwentelingen (afwentelingen, wel/geen kosten, praktijkrijp)

- niet praktijkrijp (niet praktijkrijp, wel/geen kosten, wel/geen afwentelingen).

Wat afwentelingen van mitigatiemaatregelen betreft is onderscheid gemaakt naar:

- afwentelingen van broeikasgasemissies naar andere sectoren of naar het buitenland;

- afwentelingen naar andere ecologische en sociaal-maatschappelijke duurzaamheidsthema's: ammoniak uitstoot, emissies naar water, bodemkwaliteit, landschap, biodiversiteit, klimaatbestendigheid/broeikasgasemissies, en overige (o.a. voedselveiligheid, productkwaliteit, en maatschappelijke acceptatie; negatieve score op minimaal één thema in Bijlage 1$)^{4}$.

\section{Flexibele planning}

In een tweede stap is een flexibele planning uitgewerkt voor implementatie van mitigatie- en adaptatiemaatregelen, waarin er vanuit wordt gegaan dat de toekomst onzeker is en externe factoren, zoals beleid of sociaalmaatschappelijke ontwikkelingen, kunnen veranderen en daarmee de sector beïnvloeden. In een flexibele planning worden daarom niet alleen een voorkeursroute maar ook alternatieve routes in beeld gebracht, en de mogelijkheid om de voorkeursroute te verleggen wanneer omstandigheden daarom vragen. Deze methode is afgeleid van de aanpak in het Deltaprogramma, beschreven door Haasnoot en collega's (bijv. Haasnoot et al., 2013). Naast de routekaart voor de implementatie van mitigatie- en adaptatiemaatregelen worden handelingsperspectieven beschreven voor de sector en beleid, en aanbevelingen voor onderzoek.

\subsection{Opbouw van het rapport}

Dit rapport beschrijft de emissiereductieopgave en beschikbare mitigatiemaatregelen voor de melkveehouderij (Hoofdstuk 2), en de mogelijke gevolgen van klimaatverandering en potentiële adaptatiemaatregelen (Hoofdstuk 3). In Hoofdstuk 4 wordt de routekaart omschreven voor implementatie van mitigatie- en adaptatiemaatregelen op de korte (2030) en middellange (2050) termijn.

\footnotetext{
3 Voor enkele mitigatiemaatregelen was het ten tijde van de totstandkoming van dit rapport onzeker of ze meetellen in klimaatbeleid, afhankelijk van onderhandelingen.

4 Negatieve scores op energie- en landgebruik zijn niet meegenomen, i.v.m. verwevenheid met broeikasgasemissies en kosteneffectiviteit.
} 


\section{Mitigatie}

Auteurs: Theun Vellinga, Marion de Vries (Wageningen Livestock Research)

\section{$2.1 \quad$ Broeikasgasemissies melkveehouderij}

De Nederlandse zuivelsector draagt bij aan klimaatverandering via emissies van methaan ( $\mathrm{CH} 4)$, lachgas (N2O) en koolstofdioxide (CO2; gezamenlijk uitgedrukt in 'CO2 equivalenten'5, afgekort CO2e). Broeikasgasemissies vinden plaats in de gehele zuivelketen (Figuur 1).

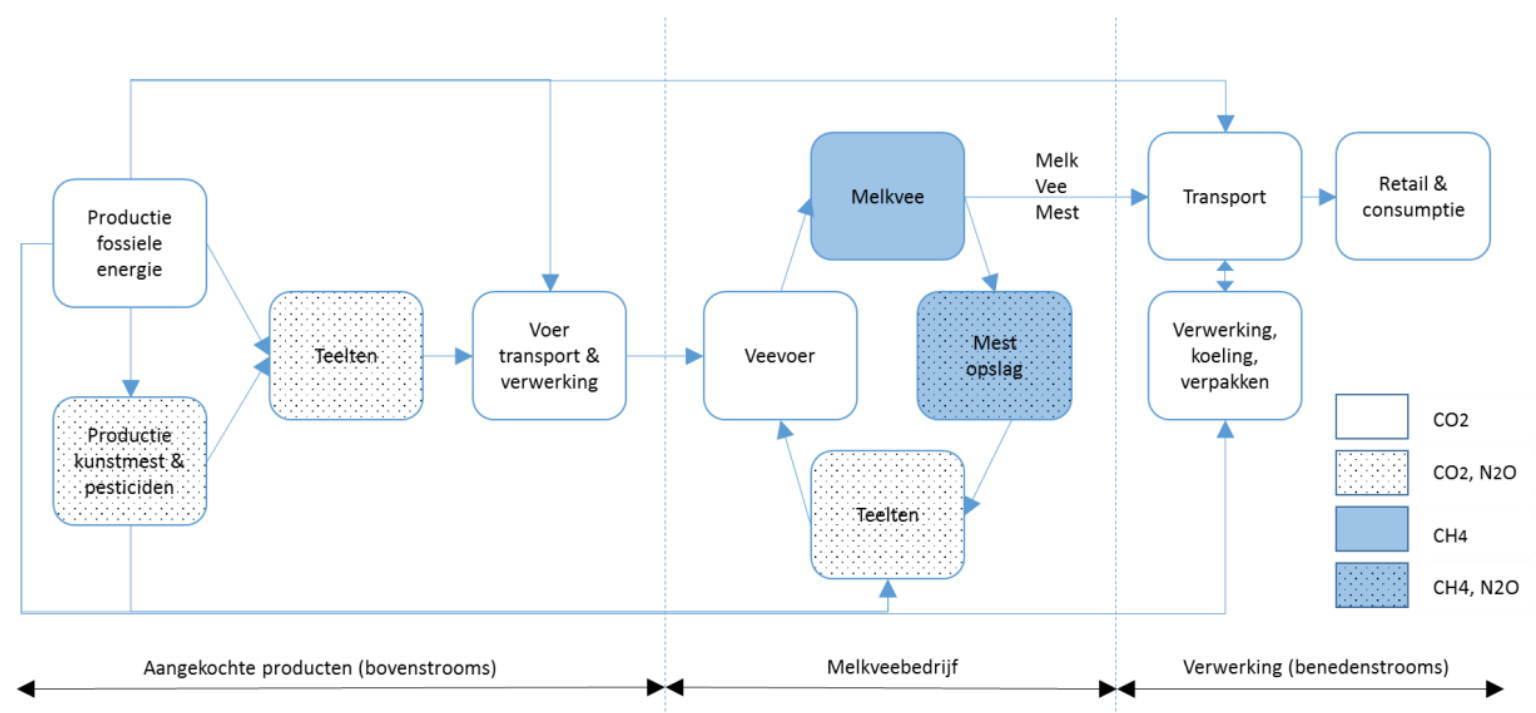

Figuur 1. Processen in de zuivelketen en gerelateerde broeikasgasemissies.

Van alle broeikasgasemissies vindt bijna twee derde plaats op het melkveebedrijf (met name pensfermentatie en mest) en bijna een derde bij de productie van aangekochte producten (met name kunstmest en veevoer; Figuur 2). De overige emissies vinden plaats tijdens transport en verwerking van producten.

\footnotetext{
5 De broeikasgassen lachgas, methaan en koolstofdioxide worden samen uitgedrukt in hoeveelheden $\mathrm{CO} 2$ equivalenten (CO2e), waarbij lachgas en methaan zwaarder meewegen dan koolstofdioxide (265, 28, en 1 CO2e, respectievelijk; IPCC, 2014). Emissies kunnen worden uitgedrukt in totaal emissievolume ( $\mathrm{kg} \mathrm{CO2e}$ ) of een emissie intensiteit ( $\mathrm{kg}$ CO2e per kilogram melk of vlees).
} 


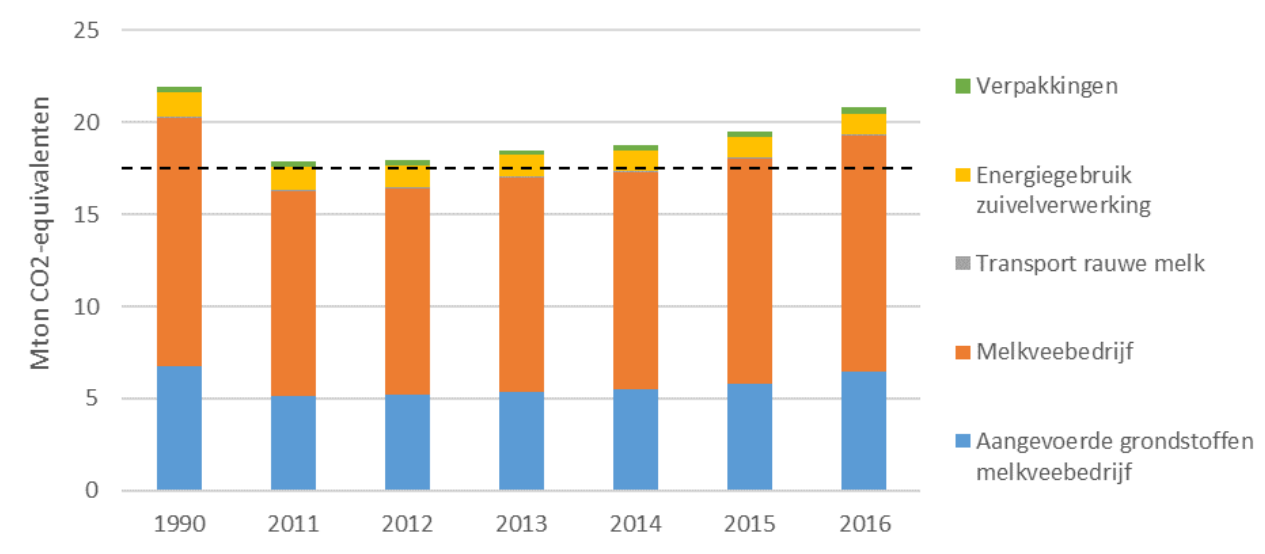

Figuur 2. Totale broeikasgasemissies Nederlandse zuivelketen in 1990 en tussen 2011 en 2016 (bron: Doornewaard et al., 2017). De horizontale stippellijn geeft het ten doel gestelde emissieniveau van de Duurzame Zuivelketen aan om 20\% reductie van broeikasgassen te realiseren in 2020 ten opzichte van 1990.

Meer dan de helft van de broeikasemissies in de zuivelketen is afkomstig van methaan (Figuur 3). Methaan wordt gevormd bij pens- en darmfermentatie en emitteert uit mestopslagen. Ongeveer een derde van de totale emissies is afkomstig van koolstofdioxide, welke met name bij de productie van aangekochte producten wordt gevormd door verbruik van fossiele brandstoffen (diesel, gas, elektriciteit). Lachgas draagt iets meer dan $10 \%$ bij, en wordt gevormd tijdens omzettingen van nitraat en ammonium in de bodem en in mest.

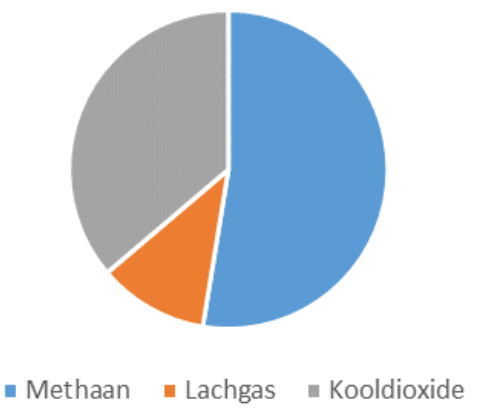

Figuur 3. Bijdrage van methaan, lachgas en koolstofdioxide in totale broeikasgasemissies uit de zuivelketen (exclusief transport van rauwe melk en verwerking; bron: Doornewaard et al., 2017).

Alleen de $\mathrm{CO} 2$ emissies die worden gevormd door benutting van fossiele voorraden (zoals kolen, olie, gas, bodemorganische stof en bovengrondse biomassa) dragen bij aan de toename van broeikasgassen. Dit is de zogenoemde lange koolstofkringloop, omdat deze al vaak duizenden jaren en langer in de bodem is opgeslagen. Bij de korte kringloop ontstaat $\mathrm{CO} 2$ bij benutting van recent gevormde biomassa (zoals plantaardige en dierlijke producten). De $\mathrm{CO} 2$ uit de korte kringloop valt niet onder broeikasgasemissies omdat deze worden vastgelegd en binnen enkele jaren weer terugkeren in de atmosfeer.

\section{Kwantificeren van broeikasgasemissies}

Broeikasgasemissies uit de melkveehouderij worden meestal op één van de volgende niveaus berekend:

- Emissies op ketenniveau; hierbij worden methaan, lachgas en koolstofdioxide emissies in de zuivelketen meegeteld, inclusief de emissies van aangekochte producten zoals veevoer en kunstmest en de emissies die plaatsvinden bij de verwerking van zuivelproducten. De keten staat centraal en ook emissies buiten de landsgrenzen worden meegenomen. Voor het berekenen van de hoeveelheid broeikasgasemissies wordt doorgaans een 'Levens Cyclus 
Analyse' (LCA) gebruikt; een internationaal geaccepteerde methode om emissies in de gehele productieketen te berekenen. Hiervoor zijn ook op internationaal niveau spelregels opgesteld (bijv. PEFCR voor zuivel, 2018 en IDF, 2015). Een belangrijk voordeel van een LCA is dat deze eventuele afwentelingen van mitigatiemaatregelen in de keten meeneemt. Wanneer broeikasgasemissies per eenheid melk of vlees worden uitgedrukt wordt dit aangeduid als 'emissie intensiteit' (bijv. CO2e/kg melk).

- Emissies op sectorniveau: hierbij worden alleen de emissies van methaan en lachgas (zogenaamde 'overige broeikasgassen') meegeteld, en alleen de emissies die plaatsvinden op het melkveebedrijf zelf. Deze methodiek is gebaseerd op de rekenwijze zoals het Intergovernmental Panel on Climate Change (IPCC) voorschrijft en betreft alleen de emissies van methaan en lachgas op het primaire bedrijf binnen de eigen landsgrenzen. Deze methode wordt gehanteerd bij de nationale Emissieregistratie in de zogenoemde 'National Inventory Reports', welke volgens afspraken jaarlijks de landelijke emissieafspraken evalueert.

De zuivelsector werkt veelal met de ketenbenadering (LCA) om totale emissies uit de sector en emissie intensiteit van producten te bepalen. In deze ketenbenadering worden emissies in de aanvoerketen en op het bedrijf wel meegenomen, maar emissies die plaatsvinden nadat producten het melkveebedrijf verlaten (bijv. zuivelverwerking, retail, consumptie) meestal niet. Dit wordt aangeduid als zgn. cradle-to-farm gate systeemgrenzen.

Er zijn verschillende rekeninstrumenten op de markt voor het berekenen van broeikasgasemissies, zoals de Nederlandse KringloopWijzer en internationaal gebruikte Cool Farm Tool. Internationaal wordt een gelijk speelveld ontwikkeld voor het berekenen van broeikasgasemissies via onder meer de Product Environmental Footprint Category Rule (PEFCR) voor zuivel, veevoer en andere sectoren. De PEFCR gebruikt net als de KringloopWijzer een ketenbenadering (LCA). De mengvoersector werkt aan een International Feed LCA Instituut, ter ondersteuning van het gelijke speelveld in PEFCR en om te werken aan mitigatie in de veevoerketen.

\section{Emissieniveau Nederlandse melkveehouderij}

Op ketenniveau was in 2016 de totale uitstoot van broeikasgassen uit de Nederlandse zuivelketen 19.3 Mton CO2e (Sectorrapportage Duurzame Zuivelketen (Doornewaard et al., 2017), o.b.v. een LCA en cradle-to-farm gate systeemgrenzen $)^{6,7}$. Dit stond gelijk aan een emissie intensiteit van $1.15 \mathrm{~kg}$ CO2e per kg melk. In 2016 hadden de 5\% best presterende bedrijven een emissie intensiteit lager dan $0.98 \mathrm{~kg} \mathrm{CO} 2$ e per kg melk, en de $25 \%$ slechtst presterende bedrijven een emissieniveau hoger dan $1.28 \mathrm{~kg} \mathrm{CO} 2 \mathrm{e}$ per kg melk.

De totale uitstoot van broeikasgasemissies uit de zuivelsector is een functie van het melkvolume en de emissie intensiteit (bijv. emissies per kg melk). Na 1990 is de totale uitstoot van broeikasgasemissies uit de zuivelsector gedaald, zowel wat betreft emissie-intensiteit als totale uitstoot. Belangrijkste factoren die bijdroegen aan deze daling waren een hogere melkproductie per koe (methaan) en de invoering van het mestbeleid (lachgas). Omdat het melkvolume ongewijzigd bleef in die periode, stond daling van de emissie-intensiteit gelijk aan daling van het emissievolume. Vanaf het jaar 2008 stagneerde de daling van de totale uitstoot, en in recente jaren nam het emissievolume weer toe. De toename wordt veroorzaakt door het productievolume en een vrijwel gelijkblijvende emissie-intensiteit (Figuur 4).

\footnotetext{
6 In de berekeningen van Doornewaard et al. (2017) zijn emissies door verandering in landgebruik niet meegenomen. Organische stof in de bodem en bij bossen horen bij de lange koolstof kringloop. Bij verandering van landgebruik kan organische stof of bovengrondse biomassa worden afgebroken en is er een bijdrage aan de emissie van $\mathrm{CO}_{2}$. Omgekeerd kan er ook $\mathrm{CO}_{2}$ worden vastgelegd in organische stof en biomassa. De totale emissie van veengronden is $4.3 \mathrm{Mton}^{\mathrm{CO}_{2}}$ (Van den Akker et al., 2010).

7 Post-farm gate broeikasgasemissies (zuivelverwerking) bedroegen 1,5 Mton CO2e (Doornewaard et al., 2017).
} 


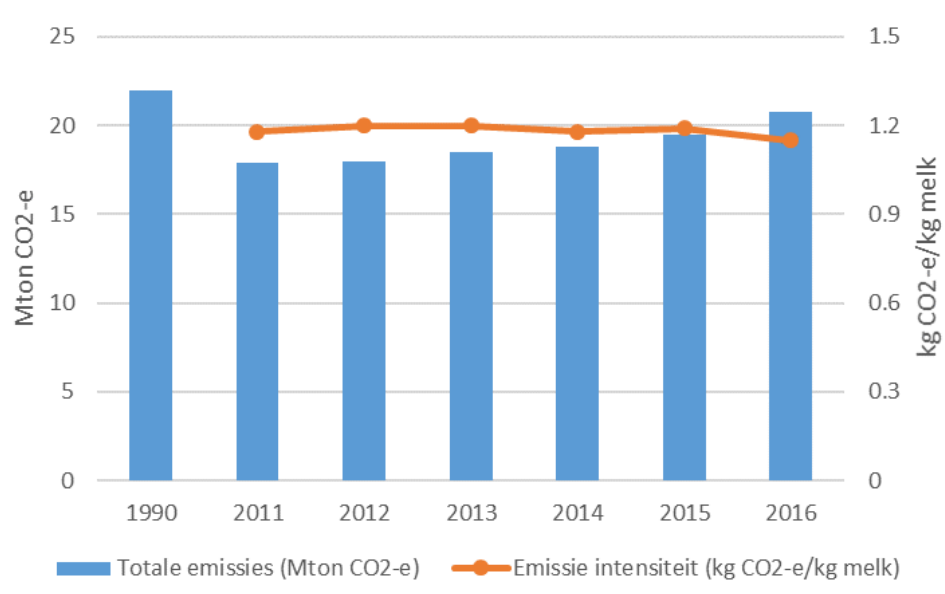

Figuur 4. Totale broeikasgasemissies (in Mton CO2e; $1^{e}$ verticale as) en emissie intensiteit (in $\mathrm{kg}$ CO2e/kg melk; $2^{e}$ verticale as) van de zuivelketen in 1990 en tussen 2011 en 2016 (bron:

Doornewaard et al., 2017).

Op sectorniveau (d.w.z. alleen de emissies van methaan en lachgas op melkveebedrijven) was de totale emissie uit de zuivelsector in 2016 ongeveer 12.5 Mton (National Inventory Report (NIR); Coenen et al., 2016), wat gelijk staat aan ongeveer $65 \%$ van de uitstoot van broeikasgassen uit de zuivelketen.

\section{$2.2 \quad$ Klimaatbeleid}

Reductiedoelstellingen in sectoraal, nationaal en Europees beleid vloeien voort uit het VN Klimaatakkoord van Parijs (2015), en bouwen voort op eerdere Europese doelstellingen. Doelstellingen zijn gebaseerd op reductie van totale emissievolumes (i.t.t. emissie intensiteit; zie Tabel 1).

\section{Sector}

In lijn met Nederlands beleid heeft de Duurzame Zuivelketen (DZK) ten doel gesteld om in 2020 broeikasgasemissies met 20\% te reduceren t.o.v. 1990 (stippellijn in Figuur 2), en vanaf het jaar 2011 netto emissievolumes vanuit de sector niet meer te laten stijgen ('Klimaatneutrale groei').

\section{Nederlands klimaatbeleid}

De Nederlandse overheid stelt ten doel om de uitstoot van broeikasgassen in Nederland terug te dringen met 49\% in 2030 (streefgetal; 48,7 Mton CO2) en 95\% in 2050 (Klimaatwet 2018) ten opzichte van 1990. Ook moet in 2050 de elektriciteit volledig CO2-neutraal worden geproduceerd. Aan de reductiedoelstelling van 2030 wordt invulling gegeven o.b.v. afspraken met 5 sectoren ('klimaattafels'), waaronder landbouw en landgebruik (3.5 Mton). In het zgn. Klimaatakkoord worden concrete afspraken over het verminderen van emissies en verantwoordelijke partijen vastgelegd.

\section{Europees klimaatbeleid}

Op Europees niveau heeft de EC een voorstel uitgebracht voor een verordening om broeikasgasemissies terug te dringen uit sectoren die niet onder het Europese Emissiehandelssysteem (ETS) vallen, genaamd de Effort Sharing Regulation (ESR). Voor Nederland betekent dit dat zij broeikasgasemissies uit de non- ETS sectoren, waar landbouw onder valt, moet verminderen met $36 \%$ over de periode 2005-2030. De betekenis van de Effort Sharing Regulation voor de Nederlandse melkveehouderij wordt nader toegelicht in het kader 'Effort Sharing Regulation (ESR)'.

Aangezien ESR een sectorbenadering hanteert, tellen voor de zuivelsector alleen reducties in 'overige broeikasgassen' op bedrijfsniveau direct mee (OBKG; methaan en lachgas; vergelijkbaar met NIR). Dat betekent dat alleen methaan uit de pens- en darmfermentatie en mestopslagen, en lachgasemissies uit mest en landbouwgronden direct bijdragen aan het behalen van ESR reductiedoelstellingen in de landbouw, terwijl die van aangekochte producten en energie niet direct meetellen. Over emissies en mitigatiemaatregelen die niet direct meetellen voor landbouw in de ESR 
kan de sector onderhandelen met andere non-ETS en ETS sectoren. Sectoren moeten onderling afspreken hoe ze de beoogde emissiereductie gaan realiseren ${ }^{8}$.

Tabel 1 Reductiedoelstellingen in sectoraal, nationaal en Europees beleid.

\begin{tabular}{|c|c|c|c|c|c|}
\hline Beleid & Reductiedoelstelling & Tijdspad & Wie & Niveau & Gassen \\
\hline Nederland & $\begin{array}{l}49 \% \text { reductie t.o.v. } \\
1990 \text { (streefgetal) }\end{array}$ & 2030 & $\begin{array}{l}5 \text { sectoren, incl. } \\
\text { landbouw }\end{array}$ & Melkveebedrijf & $\mathrm{CH} 4, \mathrm{~N} 2 \mathrm{O}$ \\
\hline Europa (ESR) & 36\% t.o.v. 2005 & 2030 & $\begin{array}{l}\text { Nederlandse non- } \\
\text { ETS sectoren }\end{array}$ & Melkveebedrijf & $\mathrm{CH} 4, \mathrm{~N} 2 \mathrm{O}$ \\
\hline
\end{tabular}

8 Ten tijde van de totstandkoming van dit rapport was de emissieopgave voor de Nederlandse zuivelsector nog niet vastgesteld. Ook was nog niet duidelijk of de zuivelsector een bijdrage kan leveren via vastlegging van koolstof door veranderingen in landgebruik (LULUCF; Land Use, Land Use Change and Forestry). De exacte opgave voor de melkveehouderijsector is afhankelijk van uitkomst van het onderhandelingsproces. 


\section{Effort Sharing Regulation (ESR)}

In het Klimaatakkoord van Parijs (CoP, 2015) zijn 195 staten het eens geworden over doelstellingen omtrent klimaatverandering, welke zowel mitigatie als adaptatie betreft. Voor mitigatie is afgesproken dat de globale temperatuurverandering onder de 2 graden moet blijven (streven 1,5 graad). De EU committeert zich aan de 2 graden doelstelling, door aanpassing van EU beleid:

- $\quad$ Reductiedoel: $40 \%$ in 2030 , en $80-95 \%$ in 2050 (t.o.v. 1990);

- $\quad$ Voor ETS sectoren: $43 \%$ in 2030 t.o.v. 2005;

- Voor non-ETS sectoren in gehele EU: 30\% t.o.v. 2005, doorvertaald naar een reductie per lidstaat via BNP per inwoner;

- Non-ETS sectoren omvatten gebouwde omgeving, glastuinbouw, landbouw, mobiliteit en kleinere industrie.

Implicaties voor Nederland

Voor Nederland betekent de Effort Sharing Regulation (ESR) een reductie van 36\% t.o.v. 2005 voor alle non-ETS sectoren samen (i.e. van 123 Mton in 2005 naar 79 Mton in 2030; EEA, 2016). Dat komt neer op een maximaal cumulatief emissiebudget voor non-ETS sectoren van 881 Mton CO2e in de periode 2021-2030, wat een aanvullende beleidsopgave betekent van 20 Mton CO2e (Nationale Energie Verkenning, 2016). Afhankelijk van de uitkomsten van het onderhandelingsproces kan deze opgave variëren van 0 tot 40 Mton CO2e (Ros and Daniëls, 2017). De reductie moet worden gerealiseerd via een lineaire daling van emissies richting 2030, waarbij een aantal flexibiliteitopties kunnen worden ingezet:

- $\quad$ Er mag in lichte mate worden afgeweken van de lineaire daling van emissies: als in een jaar te weinig emissiereductie wordt behaald kan dat in een volgend jaar worden ingehaald (artikel $5 ;$ max. 5\%).

- $\quad$ Een deel van de emissiereductie mag worden verrekend met emissies van ETS sectoren (artikel 6; max. 24 Mton $\mathrm{CO} 2 \mathrm{e}$ )

- $\quad$ Een deel van de emissiereductie mag worden gerealiseerd via de landgebruik sector (LULUCF) via vastlegging van koolstof in bos of landbouwgronden of vermindering van emissies uit veengronden (artikel 7; max. 13.4 Mton CO2e over de periode 2021-2030);

Inzet van de flexibiliteitopties biedt ruimte om variatie op te vangen, maar leidt niet tot een daling van emissies in non ETS sectoren, en kan er daarmee voor zorgen dat ETS sectoren achter gaan lopen op het reductiepad naar de langeretermijn emissiedoelstellingen in 2050. De doorvertaling naar sectoren is de verantwoordelijkheid van lidstaten.

Melkveehouderijsector

Voor de Nederlandse melkveehouderij bepalen de uitkomst van de berekeningen van PBL (Ros and Daniëls, 2017) en huidige onderhandelingen het uiteindelijke reductiepercentage waar de sector voor komt te staan. Aangezien ESR een sectorbenadering hanteert tellen alleen reducties in 'overige broeikasgassen' (methaan en lachgas) op bedrijfsniveau mee in de landbouw. Dat betekent dat alleen methaan uit de pens en mest en lachgasemissies uit mest en landbouwgronden bijdragen aan het behalen van reductiedoelstellingen in de landbouw, terwijl emissies gerelateerd aan aangekochte producten en energie niet direct meetellen*. Over de andere emissiereducties waar melkveebedrijven aan bijdragen maar die in ESR niet worden toegeschreven aan de landbouw (bv. energiegebruik en -productie) of buiten het bedrijf plaatsvinden (aangekocht veevoer, kunstmest) kan de sector met andere sectoren onderhandelen. Op die manie kunnen mitigatiemaatregelen zoals duurzame energieproductie of gebruik van veevoergrondstoffen met een lage carbon footprint toch nog worden meegerekend in emissiereducties. Het is nog niet vastgesteld of vastlegging van koolstof in de bodem via sturing van het landgebruik en via verandering van landgebruik (LULUCF) wordt meegeteld. Er zijn diverse onderzoeken gaande naar het maatregelenpakket en reductiepotentieel voor de Nederlandse zuivelsector.

* In de zuivelsector wordt veelal gewerkt met een ketenbenadering om emissie intensiteit te bepalen, waarbij methaan, lachgas en koolstofdioxide emissies in de gehele keten (Levens Cyclus Analyse) worden meegeteld, inclusief emissies van aangekochte producten (veevoer, kunstmest) en energie.

\section{$2.3 \quad$ Mitigatiemaatregelen}

In de afgelopen jaren is een groot aantal mitigatiemaatregelen geïdentificeerd die kunnen bijdragen aan een reductie van broeikasgasemissies in de zuivelsector. Een lijst van de meest genoemde maatregelen is opgenomen in Tabel 2. Voor een deel van de maatregelen zijn effecten op emissies beschreven in de literatuur. Dit betreft echter veelal case studies, en daarom is niet bekend welk effect op sectorniveau kan worden behaald. Daarnaast is de wetenschappelijke onderbouwing van het mitigerend effect van sommige maatregelen nog relatief schaars, vooral als het gaat over effecten van maatregelen in bedrijfsverband en op hogere systeemniveaus (keten, voedselsysteem). Naast literatuurresultaten zijn voor dit rapport tevens een aantal maatregelen toegevoegd op basis van expert opinie.

\section{Selectie van maatregelen}

In Tabel 2 zijn alleen maatregelen opgenomen waarvan bekend is (literatuur) of verwacht wordt (expert opinie) dat de maatregel op basis van een ketenbenadering een emissiereductie oplevert en waarin alle broeikasgassen zijn meegenomen $\left(\mathrm{CH}_{4}, \mathrm{~N}_{2} \mathrm{O}, \mathrm{CO}_{2}\right.$; samen uitgedrukt in ' $\mathrm{CO}_{2}$ equivalenten'). Met andere woorden; maatregelen die bijvoorbeeld alleen op dierniveau emissies reduceren of alleen methaan reduceren, maar een netto toename van emissies in de keten veroorzaken, zijn niet opgenomen. Een voorbeeld van afwenteling in de keten is het vergroten van het maisaandeel in het rantsoen: meer mais voeren kan methaanemissies uit de pens reduceren maar dit 
weegt op de korte termijn niet op tegen de eenmalige grote emissies door het scheuren van blijvend grasland t.b.v. maïs (Vellinga and Hoving, 2011; Van Middelaar et al., 2013). Indertijd is de termijn waarop de emissie van het scheuren van grasland gecompenseerd zou worden berekend op 60 jaar. Bij de nieuwe kennis over emissiefactoren per voedermiddel is deze compensatietijd waarschijnlijk minder, maar loopt nog steeds in tientallen jaren. Vice versa is ook het vervangen van maisland door blijvend grasland per saldo niet effectief op de korte termijn. Onder grasland neemt het bodem organische stof gehalte van jaar op jaar toe waardoor op langere termijn veel koolstof en organisch gebonden stikstof kan worden opgeslagen. Dit proces is niet oneindig, aangezien op langere termijn (ongeveer 100 jaar) een evenwicht wordt bereikt waarbij de organische stof nauwelijks meer toeneemt (zie kader 'Koolstofvastlegging in de bodem'). Wanneer het aandeel gras in het rantsoen wordt verhoogd, leidt dit echter tot hogere methaanemissies op dierniveau. Deze worden op korte termijn niet gecompenseerd door de toename in vastlegging van koolstof in de bodem. Een ander voorbeeld van een maatregel met netto emissietoename door afwenteling in de keten is het vervroegen van het oogststadium van gras (bijv. Van Middelaar et al., 2014; Sebek et al., 2016; Warner et al., 2017). Hoewel het voeren van jong gras leidt tot minder methaan uit de pens, gaat de winst van een lagere methaanproductie verloren door extra lachgasemissies en machinegebruik per $\mathrm{kg}$ voer en door lagere grasopbrengsten. Een ander voorbeeld is mestscheiding, waardoor kunstmest bespaard wordt doordat de stikstof in de dunne fractie beter benut kan worden (Verloop et al., 2013). Het netto effect van mestscheiding op broeikasgasemissies echter nog niet duidelijk omdat de gescheiden opslag van de dikke en dunne fractie mogelijk hoge emissies veroorzaken (mondelinge communicatie Karin Groenestein, oktober 2018). Op dit gebied is meer onderzoek nodig.

\section{Koolstofvastlegging in de bodem}

De potentie van koolstof $(C)$ vastlegging in de bodem is sterk gekoppeld aan het landgebruik. Door goed management kan het organische stofgehalte van grasland en bouwland enigszins worden verhoogd, maar de belangrijkste verhoging treedt op als bouwland wordt omgezet in grasland. De omschakeling naar meer grasland zal echter leiden tot hogere jaarlijkse emissies bij de productie van melk. Verdere verhoging van de organische stofgehalten op bestaand grasland door de natuurlijke vastlegging is beperkt, omdat veel blijvend grasland al relatief oud is en de netto vastlegging zeer beperkt is. De tabel hieronder laat zien welke vastlegging mogelijk is bij graslanden van verschillende leeftijden. Er is te zien dat de capaciteit tot vastlegging sterk afneemt met het stijgen van de leeftijd van het grasland. Dat heeft alles te maken met de opbouw van organische stof in de bodem, waarvan ook steeds weer een deel wordt afgebroken. Daar danken we ook het stikstof leverend vermogen (NLV) van het grasland aan.

Uitgaande van een gemiddelde leeftijd van het blijvende grasland van 50 jaar (wat relatief laag is, zeker voor de veenen kleiweidegebieden), is de vastlegging nog ongeveer 270 tot $510 \mathrm{~kg} \mathrm{CO} 2$ equivalenten per hectare. Daarbij is uitgegaan van een frequentie van herinzaai van eens per twaalf jaar. Gerekend over 700000 hectare grasland, is de vastlegging dan maximaal 0.19 tot 0.36 Mton $\mathrm{CO} 2$ equivalenten per jaar. Maar dat is een optimistische inschatting. Analyses van grasland over de afgelopen jaren laten geen stijging zien van het gemiddelde organische stofgehalte onder grasland. Bovendien neemt de snelheid van vastlegging af in de toekomst en biedt dit geen blijvende ruimte voor extra melkproductie.

De totale hoeveelheid $\mathrm{CO}_{2}$ die extra vastgelegd kan worden in organische stof op zand- en kleigrond wordt geschat op 1 Mton per jaar. Deze potentie zal echter op een gegeven moment afnemen, omdat de bodem dan een nieuw organische stof evenwicht bereikt. De winst zal zich vooral voordoen bij de akkerbouw, omdat daar vaak sprake is van lage gehalten aan organische stof en eenvoudiger verhogingen te bereiken zijn dan op blijvend grasland. De opbouw op blijvend grasland verloopt na een aantal jaren slechts langzaam. Door de ouderdom van blijvend grasland kan veel van de eerder vastgelegde koolstof emitteren wanneer het wordt gescheurd en omgezet naar akkerbouw. Behoud van oud grasland draagt dus weliswaar niet veel bij aan meer vastlegging, maar voorkomt wel dat een grote hoeveelheid vastgelegde koolstof vrijkomt als broeikasgas.

Tabel: Stikstof leverend vermogen (NLV), hoeveelheid bodem organische koolstof (C) en de mogelijke vastlegging van koolstof in grasland op zand- en kleigrond.

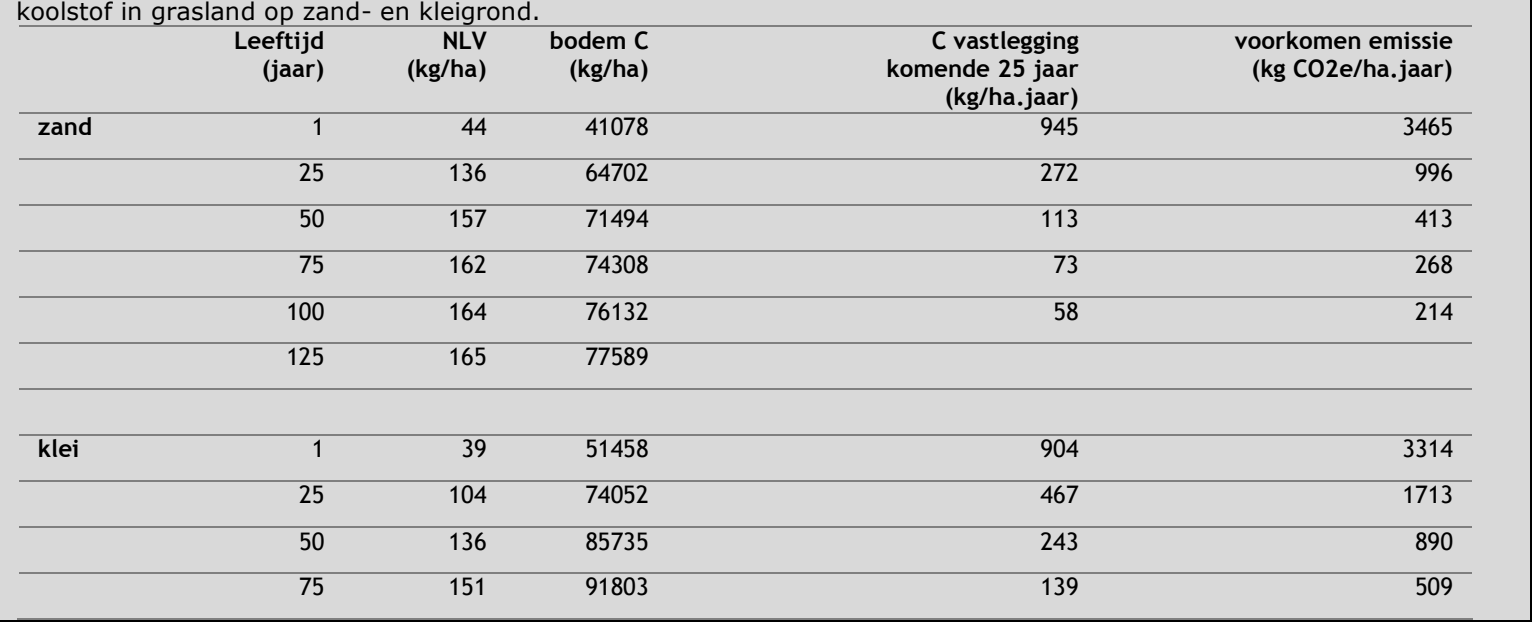


In Tabel 2 zijn alleen maatregelen opgenomen voor het melkveebedrijf, en niet voor de toeleverende industrie, verwerking, retail en consument (bijv. hernieuwbare energie, aanpak voedselverspilling). Daarnaast zijn een aantal maatregelen niet opgenomen in Tabel 2 omdat deze weliswaar effectief zijn, maar weinig potentie hebben in Nederland. Een voorbeeld is het vervangen van kunstmest door afvalstromen met bemestende waarde, zoals compost, dat al op grote schaal wordt benut (BVOR, 2018). Het gebruiken van bietenblad als voer in de veehouderij wordt wel genoemd en betreft bij maximale benutting 200 kton aan droge stof, hetgeen neerkomt op hoeveelheden van $160 \mathrm{~kg}$ droge stof per koe. Het product heeft een laag droge stofgehalte en vergt daarom hoge transportkosten. Daarnaast is het vaak verontreinigd met grond. Een ander voorbeeld is het gebruik van bijproducten in het rantsoen (bijv. tarwegist concentraat; Vellinga et al., 2009a; Goselink et al., 2014). Vandaag de dag worden de meeste bijproducten al benut. Additioneel gebruik in de melkveehouderij zou ten koste kunnen gaan van het gebruik van bijproducten en bijbehorende emissieniveaus in andere diergroepen of sectoren (bijv. Van Zanten et al., 2018). Op regionaal niveau zou de melkveehouderij een rol kunnen spelen in een circulaire economie door een efficiëntere benutting van lokale reststromen uit andere sectoren (bijv. akkerbouw, industrie) als veevoer en efficiënter gebruik van meststoffen in de regio. Een voorbeeld is het dichtbij de fabriek afzetten van reststromen om transportafstanden te beperken. Deze strategie is niet opgenomen in Tabel 2 omdat nog niet duidelijk is welke emissiereductiepotentie dit heeft in Nederland. Ook kan het op gespannen voet staan met de verhoging van de voerefficiëntie, aangezien een hogere melkproductie hogere eisen stelt aan de voeding en daarmee mogelijk beperkingen aan het gebruik van reststromen. Het benutten van reststromen uit de afvalwaterverwerking (huishoudens en industrie) is op de lange termijn een bron van organische stof en nutriënten (met name $\mathrm{P}$ en $\mathrm{K}$ ), op de kortere termijn zijn de perspectieven daarvan nog beperkt.

\section{Vermindering van emissies uit veengronden}

In het veenweidegebied halveert maaivelddaling door veenafbraak door het toepassen van onderwaterdrains in combinatie met relatief hoge slootpeilen (Hoving et al., 2015). Door de verminderde veenafbraak reduceert het vrijkomen van kooldioxide. Door veenafbraak is de $\mathrm{CO} 2$ emissie op veenweidegrond in landbouwkundig gebruik ca. 20 ton per ha per jaar (Van den Akker and Hendriks, 2014). De totale CO2 emissie in Nederland door oxidatie van veengronden is ca. 4,3 Mton per jaar (Van den Akker et al., 2010b), waarbij nog 0,4 Mton CO2 equivalent aan N2O emissie kan worden toegevoegd. In totaal is dit ca. 2,5\% van de nationale door mensen veroorzaakte CO2 emissie. De afname van de veenoxidatie (C-mineralisatie) is één op één te vertalen in een vermindering van de CO2emissie, maar is zelf moeilijk te meten. Een empirische relatie geeft een CO2emissie van $2259 \mathrm{~kg}$ CO2 per ha per mm maaivelddaling (Van den Akker et al., 2012a). Kuikman et al. (2005) berekende een N2O-emissie als gevolg van mineralisatie van veen van 0,6 tot $1,0 \mathrm{~kg} \mathrm{~N} 20$ per ha per $\mathrm{mm}$ maaivelddaling. In CO2 equivalenten (over 100 jaar) is dit $179-298 \mathrm{~kg}$ per ha per $\mathrm{mm}$ (aangenomen dat het opwarmend vermogen (GWP) van N2O 298 keer groter is dan dat van CO2).

Er zijn verschillende maatregelen om de afbraak van organische stof op veengrond te remmen of zelfs te stoppen.

- De meest drastische is het compleet vernatten van veengronden. Dan is geen landbouw in de huidige vorm meer mogelijk. Een risico is dan wel de vorming van methaan. Maar de afbraak van organische stof staat stil.

- Verhogen van het slootpeil (en daarmee de grondwaterstanden) is ook effectief. Als de Gemiddelde Laagste Grondwaterstand (GLG) met $10 \mathrm{~cm}$ wordt verhoogd, vermindert de daling van het maaiveld met $2.35 \mathrm{~mm}$ per jaar. Dat komt overeen met ruim 5 ton $\mathrm{CO} 2$ per hectare. Maar deze maatregel heeft grote gevolgen voor de bruikbaarheid van het land.

- Een effectieve maatregel is het aanbrengen van onderwaterdrainage. Daarmee wordt de laagste grondwaterstand verhoogd en in natte periode blijft het land toch redelijk begaanbaar. Dit kan leiden tot een halvering van de daling van het maaiveld. Modelberekeningen van Hendriks et al. (2008) laten voor een bemest (inclusief atmosferische $\mathrm{N}$-depositie) veenweideperceel te KTC Zegveld een daling van de N2O-emissie door onderwaterdrainage zien van $1,7(50 \mathrm{~cm}$ drooglegging) tot 8,5 (30 cm drooglegging) $\mathrm{kg} \mathrm{N2O}$ per ha per jaar, ofwel $507-2533 \mathrm{~kg} \mathrm{CO} 2$ equivalenten per ha per jaar. Bij maximale toepassing wordt de totale potentiële reductie van emissies uit veengronden voor Nederland geschat op 1,5 Mton per jaar.

\section{Clustering}

De mitigatiemaatregelen zijn in 5 clusters ingedeeld:

- Maatregelen gericht op efficiëntie: Meer of dezelfde hoeveelheid productie realiseren met minder middelen, zoals vee, nutriënten en energie, met name wat betreft voerproductie en de omzetting van voer naar melk en vlees (voederconversie). Hierdoor zijn per kg melk en vlees minder productiemiddelen nodig, waardoor de emissie intensiteit vermindert. De Nederlandse melkveehouderij kent reeds een hoge efficiëntiegraad, en daardoor een relatief lage emissie intensiteit (wereldwijd varieert de emissie intensiteit van ongeveer 1 tot $12 \mathrm{~kg} \mathrm{CO} 2-\mathrm{e} / \mathrm{kg}$ melk; Gerber et al., 2011). De mogelijkheden om de emissie intensiteit fors te verlagen zijn daardoor beperkt. Het totale emissievolume is echter een functie van emissie intensiteit en melkvolume, 
waardoor bij een toename in melkvolume het totale emissievolume kan stijgen ondanks inspanningen om de emissie intensiteit te verlagen.

- Maatregelen die ingrijpen in emissievorming: Het afremmen van emissievorming in vee, mest, bodem, gewassen en energieopwekking.

- Maatregelen die koolstofvastlegging bevorderen: Het stimuleren van koolstofvastlegging in de bodem.

- Maatregelen om gassen af te vangen (zgn. 'end-of-pipe' maatregelen): Het afvangen en omzetten van broeikasgassen naar een minder schadelijk gas, zoals het afvangen en omzetten van methaan uit mestopslagen en omzetten naar $\mathrm{CO}_{2}$.

- Structurele maatregelen: Maatregelen die de structuur van de sector wezenlijk veranderen, zoals het inkrimpen van de veestapel, of transitie van landbouwgronden naar natte landbouw, natuur, energieproductie of waterberging.

Maatregelen kunnen in meerdere clusters vallen. Een voorbeeld is mestscheiding, wat ingrijpt op emissievorming in de mestopslag (vorming van methaan, lachgas) en bij aanwending (lachgas), maar ook op efficiëntie van nutriënten en energie door een betere benutting van stikstof en besparing op kunstmeststikstof, en energieverbruik gerelateerd aan mestscheiding en kunstmestproductie (o.a. Mosquera Losada et al., 2010; Verloop, 2013).

\section{Potentiële emissiereductie}

Onderwaterdrainage in veenweidegebieden, vergisting, en methaanoxidatie laten de hoogste potentiële emissiereductie per kg melk zien (Tabel 2). Andere maatregelen in Tabel 2 variëren van 2 tot ongeveer $50 \mathrm{~g} \mathrm{CO}_{2} \mathrm{e}$ reductie per $\mathrm{kg}$ melk, met een vergelijkbare range van emissiereducties in alle sub-clusters. De grootste winst van mestvergisting zit in het voorkomen van emissies van methaan en in mindere mate in de productie van biogas. Mestvergisting blijkt echter een dure oplossing te zijn per ton vermeden $\mathrm{CO} 2$ (J.W. Straatsma, mondeling communicatie). Methaanoxidatie als mitigatie kan dan een goedkopere oplossing zijn, hoewel deze wel gecombineerd moet worden met luchtdichte opslagen om voortijdige lekkage van methaan te voorkomen. Zoals eerder genoemd betreffen resultaten echter case studies, en kan hieruit niet worden geconcludeerd welk effect op sectorniveau kan worden behaald.

Het is bij de berekening van de potentiële emissiereductie van belang rekening te houden met afwentelingen van broeikasgasemissies, zowel binnen als buiten de keten. De keuze van de voedermiddelen in het rantsoen kan bijvoorbeeld zijn weerslag hebben op emissies door landgebruiksverandering (zoals de lagere emissies bij pensfermentatie maar snelle afbraak van organische stof van het voormalige grasland wanneer gras vervangen wordt door snijmais in het rantsoen). De minste afwentelingen van broeikasgasemissies vinden plaats in de productie en het gebruik van hernieuwbare energie, omdat deze maatregelen geen of weinig interactie hebben met andere activiteiten op het melkveebedrijf. Afwentelingen van broeikasgasemissies beperken zich niet tot de zuivelketen. Bij verhoging van de melkproductie per koe of levensduurverlenging (minder jongvee) kan bijvoorbeeld sprake zijn van een verschuiving van emissies naar de vleesveesector wanneer deze veranderingen gepaard gaan met een lagere vleesproductie, en deze lagere vleesproductie wordt gecompenseerd met vlees uit de vleesveesector (Vellinga and de Vries, 2018). Voor het berekenen van effecten van mitigatiemaatregelen op een hoger aggregatieniveau (bijv. regionaal) zijn andere analysemethoden nodig dan op dit moment gangbaar zijn, en hangt de emissiereductie af van veel zaken, waaronder voeremissies (teelt, pens) en alternatieve toepassingen van reststromen (bijv. Van Zanten et al., 2018). Voorts is het van belang rekening te houden met het feit dat een reductie in emissie intensiteit (emissies per $\mathrm{kg}$ melk) niet per definitie een verlaging van het totale emissievolume betekent (zie kader 'Hoe beïnvloedt een verdere melkproductiestijging broeikasgasemissies?). 
Een verhoging van de melkproductie per koe leidt tot een lagere emissie intensiteit (emissies in CO2e (equivalenten) per kg melk). Gerber et al. (2011) stellen dat de emissie intensiteit nauwelijks meer daalt boven melkproducties van 9000 $\mathrm{kg}$ per koe per jaar. In dit geval wordt verondersteld dat de stijgende melkproducties en de daling van de emissie intensiteit worden veroorzaakt door veranderingen in het rantsoen, zoals de inzet van meer hoogwaardige producten en met name krachtvoer. Berekeningen voor de Nederlandse situatie, waarbij het rantsoen in de afgelopen jaren ongewijzigd is gebleven, laten echter een daling zien in de orde van $25-40 \mathrm{gram} \mathrm{CO}_{2} \mathrm{e} / \mathrm{kg}$ melk per $1000 \mathrm{~kg}$ productiestijging per koe (Vellinga en de Vries, 2018). In dit geval is de verhoging van de melkproductie voortgekomen uit met name een grotere opname capaciteit van de dieren. De stijging van de gemiddelde melkproductie in de afgelopen 15 jaren in Nederland bedraagt $50 \mathrm{~kg}$ per jaar. Dat komt neer op een daling van de emissie van $19-30 \mathrm{gram} \mathrm{CO}_{2} \mathrm{e} / \mathrm{kg}$ melk. Als deze trend zich doorzet, zal in de periode tot 2030 (i.e. 12 jaar) nog een daling te verwachten zijn van 16 - 24 gram $\mathrm{CO}_{2}$ e / kg melk. De gemiddelde melkproductie zal dan $9300 \mathrm{~kg}$ per koe per jaar zijn, uitgaande van een gelijkblijvend rantsoen. Zodra zich rantsoenveranderingen voordoen, is het waarschijnlijk dat deze effecten minder sterk zijn.

\section{Emissie volume}

Een verhoging van de melkproductie per koe leidt tot hogere emissies van voer en mest per dier omdat het dier meer voer opneemt. Een hogere melkproductie per koe draagt dus weliswaar bij aan lagere emissies per kg melk, maar niet per definitie aan een verlaging van het totale emissievolume. Dit hangt samen met het totale melkvolume; bij een verdere verhoging van de melkproductie per koe zullen emissies bij een gelijkblijvende veestapel toenemen, maar wanneer het totale melkvolume gelijk blijft zal de veestapel moeten krimpen en zullen emissies afnemen.

Voor wat betreft de gezamenlijke potentiële emissiereductie van vastlegging van koolstof op minerale gronden (zie kader 'Koolstofvastlegging in de bodem') en het beperken van de veenafbraak (zie kader 'Vermindering van emissies uit veengronden') is in een optimistisch scenario in 2030 de potentiële vastlegging van koolstof en beperking van de veenafbraak bereikt, te beginnen vanaf 2019. De werkelijke vastlegging neemt rechtlijnig toe van 2019 naar 2030, de afbraak neemt rechtlijnig af in diezelfde periode. In die periode van 12 jaar is de vastlegging dan 6 Mton (oplopend van 0 aan het begin naar 1.0 aan het eind van de periode) en de verminderde uitstoot 9 Mton (oplopend van 0 naar 1.5 van begin naar eind). Dat levert een theoretisch maximale vastlegging op van 15 Mton $\mathrm{CO} 2$ equivalenten. De vraag is echter of de landbouw in staat is om het management zodanig sterk te veranderen dat de maatregelen in dit theoretische scenario volledig worden uitgevoerd en toegepast. Daarnaast is de vastlegging van koolstof op landbouwgronden niet een rechtlijnig proces, maar neemt af in de loop van de jaren. Het is daarom ook de vraag in hoeverre de potentiële vastlegging gedurende meerdere jaren op hetzelfde niveau kan blijven. Er wordt gewerkt aan een systeem om de vastlegging en het bijbehorende landmanagement betrouwbaar te kunnen monitoren. Dat systeem is nog in ontwikkeling en moet volledig transparant zijn. 
Tabel 2 Literatuuroverzicht van mitigatiemaatregelen en emissiereducties in de melkveehouderij.

\begin{tabular}{|c|c|c|c|}
\hline \multirow[t]{2}{*}{ Maatregel } & \multirow[t]{2}{*}{ Toelichting } & \multicolumn{2}{|l|}{ Case studies ${ }^{1,2,3}$} \\
\hline & & $\begin{array}{l}\text { Emissiereductie } \\
\text { (g CO2e/kg melk) }\end{array}$ & Bron \\
\hline \multicolumn{4}{|l|}{ 1.Efficiëntie bevorderen } \\
\hline \multicolumn{4}{|l|}{ Vee: } \\
\hline - Hogere melkproductie per koe & $\begin{array}{l}\text { Door beter voer- en diermanagement of fokkerij maatregelen kan de voerefficiëntie en } \\
\text { melkproductie verder toenemen en emissies over een grotere hoeveelheid melk worden } \\
\text { verdeeld. Omdat emissies uit voer, dier en mest door een hogere melkproductie stijgen } \\
\text { neemt het totale emissievolume alleen af als het totale melkvolume gelijk blijft of slechts } \\
\text { licht stijgt, en daartoe de omvang van de veestapel verkleind wordt. }\end{array}$ & $\begin{array}{l}33-38 \\
(+500 \mathrm{~kg} \mathrm{melk} / \mathrm{koe}) \\
40-55 \\
(+1000 \mathrm{~kg} \mathrm{melk} / \mathrm{koe})\end{array}$ & $\begin{array}{l}\text { Van den Pol et al. (2013) } \\
\text { Vellinga and de Vries (2018) }\end{array}$ \\
\hline - Levensduurverlenging & $\begin{array}{l}\text { Door beter diermanagement, zoals een betere vruchtbaarheid en tochtigheidscontrole, kan } \\
\text { een langere levensduur worden gerealiseerd, wat leidt tot minder emissies door een lagere } \\
\text { jongveebezetting. }\end{array}$ & $\begin{array}{l}19 \text { ( } 1 \text { stuks minder } \\
\text { jongvee/10 koeien) } \\
10-20 \text { (per jaar extra } \\
\text { levensduur) }\end{array}$ & $\begin{array}{l}\text { Goselink et al. (2014) } \\
\text { Vellinga and de Vries (2018) }\end{array}$ \\
\hline - Verbeteren diergezondheid & $\begin{array}{l}\text { Het voorkomen van ziekten heeft een positief effect op de melkproductie, vruchtbaarheid } \\
\text { en levensduur, en zorgt ervoor dat minder melk wordt weggegooid wegens } \\
\text { antibioticabehandeling. }\end{array}$ & $\begin{array}{l}4 \text { (klauwaandoeningen), } \\
5 \text { (slepende melkziekte), } \\
15 \text { (klinische mastitis) }\end{array}$ & Mostert (2018) \\
\hline \multicolumn{4}{|l|}{ Nutriënten: } \\
\hline - Grasklaver & $\begin{array}{l}\text { Het toepassen van meer grasklaver in grasland zorgt voor meer vastlegging van stikstof } \\
\text { en daardoor is een lagere aanvoer van kunstmest nodig. De lagere grasopbrengst kan } \\
\text { echter additionele emissies met zich meebrengen, vanwege extra voer. Vanwege de } \\
\text { opbrengst per hectare is de netto emissiereductie vooral afhankelijk van huidige } \\
\text { bemestingsniveaus, en is de maatregel meest effectief op extensievere bedrijven. Een } \\
\text { optimalisatie van landgebruik waarin grasklaver wordt geïntroduceerd in wisselbouw met } \\
\text { mais kan emissies verlagen (Vellinga and Van Eekeren, 2017). }\end{array}$ & 20 & Berekening voor dit rapport. \\
\hline - Verbeteren bemestingsefficiëntie & $\begin{array}{l}\text { Door het verbeteren van de bemestingsefficiëntie (bijv. door beter af te stemmen op } \\
\text { specifieke perceelbehoefte) is minder kunstmest nodig, en daarmee minder emissies door } \\
\text { productie en aanwending van kunstmest. }\end{array}$ & 31 & Vellinga et al. (2009b) \\
\hline - Voorjaarsmeststof toepassen & $\begin{array}{l}\text { Voorjaarsmeststoffen bevatten een hoger aandeel ammoniumstikstof dan nitraatstikstof. } \\
\text { Nitraat spoelt sneller uit dan ammonium en kan gemakkelijker denitrificeren, met meer } \\
\text { stikstofgas als gevolg (deels } \mathrm{N}_{2} \mathrm{O} \text { ). }\end{array}$ & 6 & Schils et al. (2006) \\
\hline - Kortere periode mest uitrijden & Geen mest uitrijden na 1 augustus & $2-8$ & Vellinga et al. (2009b) \\
\hline - Opbrengstverhoging ruwvoerproductie & $\begin{array}{l}\text { Productiviteit van grasland en bouwland verbeteren, bijv. door betere bemesting, } \\
\text { voorkomen van bodemverdichting en rijschade, op peil houden van de zuurgraad } \\
\text { (grasland) en OS gehalte (bouwland). Voor de emissiereductie in dit rapport is uitgegaan } \\
\text { van een opbrengstverhoging van } 1000 \mathrm{~kg} \text { DS per ha, welke } 200-250 \mathrm{~kg} \text { CO2e bespaart op } \\
\text { ruwvoeraankoop. Wanneer de opbrengstverhoging wordt omgezet in besparing op } \\
\text { kunstmest kan meer emissiereductie gerealiseerd worden. }\end{array}$ & 2 & Berekening voor dit rapport. \\
\hline - Verbeteren ruwvoerconservering & Voorkomen dat ruwvoer in voederwaarde daalt of als afval eindigt. & $\begin{array}{l}\text { 2-14 (verminderen } \\
\text { broeiverliezen) }\end{array}$ & Schooten and Philipsen (2012) \\
\hline \multicolumn{4}{|l|}{ Energie: } \\
\hline $\begin{array}{l}\text { - Energie besparen (diesel, gas, } \\
\text { elektriciteit) }\end{array}$ & $\begin{array}{l}\text { Diesel besparende (bijv. passend machinepark/capaciteit, 'het nieuwe trekkerrijden', } \\
\text { minimaal aantal bewerkingen, transport afstand voer beperken), gas besparende (bijv. } \\
\text { zuiniger boiler, minder warmwater) en elektriciteit besparende maatregelen (rondom } \\
\text { melkwinning (bijv. koeling/warmteterugwinning/voorkoeling/freq.regelaar), verlichting } \\
\text { (bijv. besparende lampen/schemerschakelaar/bewegingsmelder), en andere processen). }\end{array}$ & $\begin{array}{l}2 \text { (grond dichter bij huis, } \\
\text { voorkoeling), } 7 \\
\text { (warmteterugwinning), } \\
10 \text { (trekker) }\end{array}$ & $\begin{array}{l}\text { Van den Pol et al. (2013), } \\
\text { Vellinga et al. (2009b), } \\
\text { Roetert (2009) }\end{array}$ \\
\hline
\end{tabular}




\begin{tabular}{|c|c|c|c|}
\hline \multirow[t]{3}{*}{ Maatregel } & \multirow[t]{3}{*}{ Toelichting } & \multicolumn{2}{|l|}{ Case studies ${ }^{1,2,3}$} \\
\hline & & Emissiereductie & Bron \\
\hline & & (g CO2e/kg melk) & \\
\hline \multicolumn{4}{|l|}{ 2.Emissievorming verminderen } \\
\hline \multicolumn{4}{|l|}{ Vee: } \\
\hline - $\quad$ Rantsoenaanpassingen, bijv.: & $\begin{array}{l}\text { Rantsoenaanpassingen om de vorming van methaan (methanogenese) in het } \\
\text { spijsverteringskanaal af te remmen. }\end{array}$ & & \\
\hline $\begin{array}{l}\text { Betere verhouding eiwit/energie op } \\
\text { pensniveau }\end{array}$ & $\begin{array}{l}\text { Indien eiwitgehalten in het rantsoen nog te hoog zijn, bijv. door krachtvoer met lager RE } \\
\text { gehalte. }\end{array}$ & 3 & $\begin{array}{l}\text { Vellinga et al. (2009b), } \\
\text { Roetert (2009) }\end{array}$ \\
\hline - Hoger vetgehalte krachtvoer & $\begin{array}{l}\text { Toevoeging van olie en vet aan krachtvoer. De toepassing is beperkt vanwege } \\
\text { rantsoeneisen en hardheid mengvoer, en mag de melksamenstelling niet beïnvloeden. Per } \\
\text { procent vet kan de methaanproductie met } 4-5 \% \text { reduceren. }\end{array}$ & 9 (lijnzaad) & Van Middelaar et al. (2014) \\
\hline$\circ \quad$ Additieven & $\begin{array}{l}\text { Toevoeging van additieven aan het rantsoen kan enterische methaanemissies reduceren, } \\
\text { bijvoorbeeld nitraat, 3NOP. }\end{array}$ & $32-48$ (nitraat) & $\begin{array}{l}\text { Van Middelaar et al. (2014), } \\
\text { Hristov et al. (2013), } \\
\text { Klop (2016) }\end{array}$ \\
\hline - $\quad$ Fokkerij & Genetische selectie op dieren met een lagere enterische methaan emissie. & N.A. & $\begin{array}{l}\text { de Haas et al. (2016), } \\
\text { Pryce and Bell (2017) }\end{array}$ \\
\hline \multicolumn{4}{|l|}{ Mest: } \\
\hline $\begin{array}{l}\text { Combinatie primaire mestscheiding, } \\
\text { frequente afvoer, gesloten opslag en } \\
\text { gassen afvangen. }\end{array}$ & $\begin{array}{l}\text { Minder lachgas- en methaanvorming in stal (primaire scheiding, frequente afvoer), } \\
\text { mestopslag (gassen afvangen), en bij aanwending; betere benutting van stikstof, en } \\
\text { besparing op kunstmeststikstof en -energieverbruik. }\end{array}$ & $50-150$ & $\begin{array}{l}\text { Petersen et al. (2013), Sebek et al. } \\
\text { (2016) }\end{array}$ \\
\hline - Koude opslag mest & $\begin{array}{l}\text { Minder methaanvorming uit mestopslag door minder bacteriële activiteit. Voor varkensmest } \\
\text { zijn emissiereducties van } 23-43 \% \text { gerapporteerd (Groenestein et al., 2012), maar verwacht } \\
\text { wordt dat dit effect zal kleiner zijn voor melkvee omdat de staltemperatuur al relatief laag is } \\
\text { in de stal. }\end{array}$ & N.A. & \\
\hline - $\quad$ Aanzuren mest & Minder methaanvorming uit mestopslag door verlaging pH mest. & $20-50$ & Petersen et al. (2012) \\
\hline \multicolumn{4}{|l|}{ Bodem: } \\
\hline - Nitrificatieremmers & Remmen van lachgasemissies uit de bodem. & $30-60$ & Kuikman et al. (2010) \\
\hline $\begin{array}{l}\text { - Onderwaterdrainage veen / } \\
\text { peilverhoging }\end{array}$ & $\begin{array}{l}\text { In veenweidegebieden halveert het toepassen van onderwaterdrains (buisdrains onder } \\
\text { slootpeilniveau die zowel draineren als infiltreren) in combinatie met relatief hoge } \\
\text { slootpeilen de maaivelddaling door veenafbraak (Hoving et al., 2015). De verminderde } \\
\text { veenafbraak reduceert het vrijkomen van kooldioxide en lachgas. Onderwaterdrains zorgen } \\
\text { voor een verdere reductie van emissies naast peilverhoging, maar het verschil t.o.v. } \\
\text { peilverhoging zonder onderwaterdrains is klein (Jansen et al., 2009). Door de } \\
\text { onderwaterdrains blijft het land echter begaanbaar ondanks het relatief hoge slootpeil. } \\
\text { Mogelijkheden voor natte veevoerteelten worden verkend (bijv. lisdodde). }\end{array}$ & $100-167$ & $\begin{array}{l}\text { Lesschen et al. (2012), Jansen et al. } \\
\text { (2009) }\end{array}$ \\
\hline \multicolumn{4}{|c|}{. } \\
\hline - Zon- en windenergie & $\begin{array}{l}\text { De productie van zon- en windenergie kan } \mathrm{CO} 2 \text { uitstoot door verbruik van fossiele energie } \\
\text { op en buiten (verkoop) de zuivelketen reduceren. }\end{array}$ & 29 (zon), 29 (wind), 48 & $\begin{array}{l}\text { Hoving and Velthof (2006), } \\
\text { Velthof et al. (2010) }\end{array}$ \\
\hline \multicolumn{4}{|l|}{ 3.Vastlegging van koolstof } \\
\hline \multicolumn{4}{|l|}{$\begin{array}{l}\text { Grasland (opbouw organische stof (OS) } \\
\text { versterken): }\end{array}$} \\
\hline $\begin{array}{l}\text { Niet scheuren van blijvend grasland voor } \\
\text { een korte tussenteelt van voedergewas } \\
\text { of ander gewas }\end{array}$ & $\begin{array}{l}\text { Bij het scheuren van grasland wordt in korte tijd een grote hoeveelheid OS afgebroken. Dit } \\
\text { gaat gepaard met een grote hoeveelheid broeikasgasemissies en een daling van het stikstof } \\
\text { leverend vermogen (NLV) van de bodem, waardoor de opbrengst daalt en meer }\end{array}$ & $20-40$ & $\begin{array}{l}\text { Hoving and Velthof (2006), } \\
\text { Velthof et al. (2010) }\end{array}$ \\
\hline
\end{tabular}

24 | Wageningen Livestock Research Rapport 1131 
stikstofbemesting nodig is (of meer aankoop van voer). Het verlies aan OS wordt in de opvolgende jaren weer gecompenseerd (bijv. Hoving en Vellinga, 2010). Om minder herinzaai te realiseren is goed graslandmanagement van belang (bv. betere maai- en bemestingspraktijken, bodemverdichting voorkomen)

Herinzaai beperken en vervangen door

Wanneer vernieuwing van de graszode toch nodig is om de productie en kwaliteit van gras en ruwvoer op peil te houden is doorzaaien van gras een alternatief, waarbij grondbewerking volledig achterwege blijft en zonder substantiële aantasting van het hoge gehalte aan OS onder blijvend grasland.

Om emissies te beperken wordt aanbevolen in gras-mais wisselbouw de grasfase in de rotatie te beperken tot twee, of hooguit drie jaar. Een langere periode van gras leidt tot grotere verliezen van bodemorganische stikstof (nitraatuitspoeling), en daarmee hogere grasfase beperken tot maximaal 3 jaa broeikasgasemissies.

Bouwland:

Niet-kerende grondbewerking

Gewaskeuze aanpassen

Niet-kerende grondbewerking kan de afbraak van OS beperken.

A teelt van gewassen die meer stoppel, wortel

Afwisseling van bouwland en grasland heeft, mits goed uitgevoerd, voordelen voor OS

voorziening op bouwland.

Groenbemesters

geproduceerd.

(g CO2e/kg melk)

Aanvoer OS via mest/compost

Agroforestry

De aanvoer van OS via mest word

.

Teett van bomen in combinatie met landbouwgewassen of in perceelsrande

4.Gassen afvangen (end-of-pipe)

Vergisting (bij voorkeur i.c.m. frequente afvoer uit de stal)

Methaanoxidatie

Mono-vergisting (alleen mest) en co-vergisting (mest samen met ander organisch

materiaal) leiden tot minder (m.n.) methaanemissie doordat mest direct uit de stallen wordt 100-130 (co-vergisting

verwijderd, en minder $\mathrm{CO} 2$ emissie door de omzetting naar biogas. Co-vergisting is alleen

zinvol als producten niet ingezet kunnen worden als veevoer (De Vries, 2014).

Methaan wordt afgevangen en thermisch (affakkelen) of microbieel (via (bijv. bodem-)

acteriën) omgezet in het minder schadelijke kooldioxide. Door thermische oxidatie kan

reductie van $62 \%$ van emissies worden bereikt. Ook onder dichte vloeren kan gas worden

afgevangen. Stallucht is technisch mogelijk, maar te kostbaar.

\section{Structurele maatregelen}

Omvang

Inkrimpen van de veestapel om totale emissievolume te reduceren.

ransitie landbouwgronden naar (natte)

natuur

Minder voerproductie en emissies die daarmee gepaard gaan, en meer koolstofopslag in gevormde natuur (biomassa, bodem). Bij natte natuur kan daarnaast ook veenoxidatie worden voorkomen.
Geen effect op emissie/kg

melk

Geen effect op emissie/kg

melk
(2-10

$10-20$

Velthof et al. (2010)

Vellinga and Van Eekeren (2017)

Schils et al. (2006)

$62 \%$ van methaan uit

mest (thermische

(in ontwikkeling)

oxidatie)

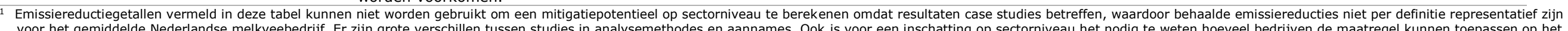

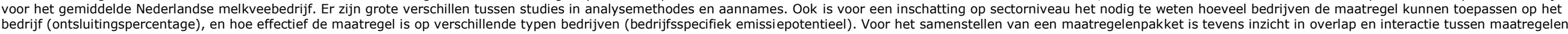
bedrijf (ontsluitingspercentage), en hoe en meer opgeteld.
van belang; effecten kunnen niet zonder men

2 N.A. betekent geen studie beschikbaar of niet opgenomen wegens gebrek aan betrouwbaarheid
3 Emissiereductie in totale $\mathrm{CO} 2$ equivalenten (methaan, lachgas en kooldioxide) op ketenniveau. 


\subsection{Interactie met andere duurzaamheidsthema's}

Voor de mitigatiemaatregelen in Tabel 2 is de interactie met andere duurzaamheidsthema's geëvalueerd, alsook de kosteneffectiviteit en praktijkrijpheid van maatregelen. Resultaten zijn opgenomen in Bijlage 1. Er is gekeken naar effecten van een maatregel op het gebruik van energie en landbouwgrond, emissies van ammoniak naar de lucht, emissies van $\mathrm{N}$ en $\mathrm{P}$ naar grond- en oppervlaktewater, bodemkwaliteit, landschap, biodiversiteit en klimaatbestendigheid. Hierbij zijn alleen duidelijk positieve (synergie) en negatieve (afwenteling) effecten meegenomen ${ }^{9}$.

Samenvattend kan gesteld worden dat iets minder dan een derde van de mitigatiemaatregelen in Bijlage 1 afwentelingen heeft, met name wat betreft energie- en landgebruik, en in mindere mate voor ammoniak, landschap en 'overige' afwentelingen. Afwentelingen met energie- en landgebruik zijn met name aanwezig onder maatregelen die ingrijpen in emissievorming, omdat het beïnvloeden van emissievorming in sommige gevallen energie kost (bv. koude opslag mest), landbouwgrond opeist (hernieuwbare energieproductie) of voor lagere opbrengsten zorgt (bv. peilverhoging veen). Inzetten van maatregelen die energie verbruiken kan mogelijk wel aantrekkelijk zijn wanneer dit gebeurt op basis van hernieuwbare energie en een bijdrage leveren aan het balanceren van het elektriciteitsnet. Over het geheel genomen zijn er meer synergiën dan afwentelingen. Maatregelen in het cluster koolstofvastlegging hebben de minste afwentelingen, en de meeste synergiën. Ongeveer een derde van de maatregelen is kosteneffectief en ongeveer de helft kost de veehouder geld. Met name de maatregelen gerelateerd aan mest kosten geld. De meeste maatregelen zijn praktijkrijp, en slechts een beperkt aantal maatregelen vergt nog veel extra onderzoek.

In de volgende alinea's worden de belangrijkste interacties per cluster toegelicht.

\section{Efficiëntie bevorderen}

Bij verschillende efficiëntiemaatregelen is er een gunstige interactie met energie, mineralen en ammoniakuitstoot, bijvoorbeeld door minder nitraatverliezen bij een verbeterde bemestingsefficiëntie en minder ammoniak uitstoot door mestscheiding. Met name de maatregelen gericht op mineralenefficiëntie hebben een gunstig effect op ammoniak uitstoot, $\mathrm{N}$ en $\mathrm{P}$ emissies, en bodemkwaliteit. Het toepassen van voorjaarsmeststof gaat gepaard met meer ammoniak uitstoot. Alle maatregelen zijn praktijkrijp. De meest maatregelen zijn kosteneffectief, behalve enkele gerelateerd aan mest en bemesting.

Voor melkproductieverhoging per koe zijn effecten lastig in te schatten omdat dit erg afhankelijk is van uitgangspunten in de analyse. In dit rapport is uitgegaan van een melkproductieverhoging door verbetering van de voerefficiëntie (betere voedermiddelen en efficiënter voersysteem) bij een gelijkblijvend aantal koeien en hoger melkvolume op bedrijfsniveau. In de huidige situatie waarin fosfaat excretie de limiterende factor is kan echter meer vee gehouden worden en meer melk geproduceerd worden. Dit kan negatief uitwerken (meer druk) voor diverse duurzaamheidsthema's. Daarnaast kan door verhoging van de melkproductie per koe en levensduurverlenging emissies naar

\footnotetext{
9 Wanneer in Bijlage 1 geen effect is aangegeven betekent dit niet dat het effect per definitie afwezig is, maar dat niet met voldoende zekerheid kan worden gezegd of een positief of negatief effect bestaat. Daarnaast zal het effect van maatregelen in de praktijk sterk afhankelijk zijn van locatie en bedrijfstype, en de manier waarop de maatregel geïmplementeerd wordt.
} 
de vleesveesector verschuiven wanneer een lagere vleesproductie wordt gecompenseerd met vlees uit de vleesveesector.

Het telen van alternatieve voedergewassen zoals grasklaver kan bijdragen aan het bevorderen van de biodiversiteit (Zijlstra et al., 2015). Grasklaver geeft echter kans op een hogere nitraatuitspoeling (Schils, 2002) en een lagere ruwvoeropbrengst. Door klimaatverandering is grasklaver mogelijk moeilijker te handhaven in blijvend grasland, aangezien het veel van het management en een goede bodemstructuur en vochtvoorziening vraagt. Witte klaver is geschikt voor beweiding, terwijl rode klaver goed bij een gras-mais vruchtwisseling past (financieel en qua emissies; Vellinga and Van Eekeren, 2017; Eekeren et al., 2018).

Wat klimaatbestendigheid betreft is het tot dusver niet duidelijk in hoeverre een hogere efficiëntiegraad de kwetsbaarheid van bedrijven vergroot onder onvoorziene ongunstige omstandigheden, zoals effecten van klimaatextremen. Dit kan mogelijk effect hebben op de prestaties en emissie intensiteit van bedrijven, en het realiseren van een hogere efficiëntie bemoeilijken.

Maatregelen kunnen op verschillende niveaus verschillend uitwerken wat betreft klimaatbestendigheid. Wanneer maatregelen bijvoorbeeld tot een lagere veebezetting leiden is er op bedrijfsniveau meer ruimte om voldoende voer te produceren en eventuele schokken op te vangen. Op dierniveau is het nog niet duidelijk in hoeverre dieren met een hogere productiviteit kwetsbaarder zijn voor effecten van klimaatverandering (bijv. ziekten, hittestress, variatie in voerkwaliteit). De relatie tussen efficiëntie en klimaatbestendigheid behoeft nader onderzoek.

\section{Ingrijpen in emissievorming}

Maatregelen die ingrijpen op biologische processen in vee kunnen ethisch omstreden zijn, zoals het toevoegen van additieven aan het rantsoen om methaanvorming te voorkomen. Het toevoegen van nitraat in het rantsoen kan daarnaast tot meer stikstof op de balans leiden, wat moet worden opgelost door het voeren van eiwitarmer krachtvoer. Het lage eiwitgehalte van CCM is gunstig voor de stikstofbalans. Toevoegmiddelen mogen geen residuen achterlaten die effect hebben op de voedselveiligheid. Tegenwoordig worden harde vetten verwerkt in mengvoeders voor rundvee. Dat kan gevolgen hebben voor de vetsamenstelling, en dus de productkwaliteit van melk. Voorts kan de keuze van de voedermiddelen zijn weerslag hebben op emissies door landgebruiksverandering. Succesvolle pilotstudies hebben plaatsgevonden voor wat betreft genetische selectie tegen methaanvorming, maar deze techniek is nog niet praktijkrijp (mondelinge communicatie Roel Veerkamp, augustus 2018).

Alle genoemde maatregelen die ingrijpen op emissievorming uit mest dragen bij aan vermindering van de ammoniak uitstoot, maar veel van deze maatregelen kosten energie.

Minder veenafbraak leidt tot minder maaivelddaling, waardoor minder nutriënten en sulfaat vrijkomen. Dit is gunstig voor de waterkwaliteit, en daarmee ook voor biodiversiteit. In veen kan klimaatverandering een zichzelf versterkend effect hebben: door warmere en drogere omstandigheden kunnen broeikasgasemissies door maaivelddaling met $40-50 \%$ toenemen (meest extreme klimaatscenario; Jansen et al., 2009). Onderwaterdrains, vooral in combinatie met geringere drooglegging, kunnen deze toename in emissies beperken en bieden de mogelijkheid om met hogere slootpeilen het land toch begaanbaar te houden, ook in nattere periodes.

Wat energiemaatregelen betreft kan er bezwaar zijn tegen landschappelijke veranderingen door de energieproductie op basis van wind, zon of biomassa. Bij co-vergisting kunnen er ethische bezwaren 
zijn vanwege de competitie met humaan voedsel en veevoer (De Vries, 2014). Volgens regelgeving neemt daarnaast door co-vergisting de hoeveelheid mest toe, omdat de totale hoeveelheid digestaat als mest gezien wordt. Wanneer zonneparken op landbouwgrond worden aangelegd kan dit ten koste van de voerproductie gaan en gevolgen hebben voor andere aspecten van de bedrijfsvoering, zoals mestafzet. Bij zonneparken worden dichtheden voorgesteld, waarbij nog productie van gewassen mogelijk is (Spruijt and Terbijhe, 2016). De constellatie waarbij het gewas geoogst kan worden en de zonnepanelen zijn geplaatst, is nog onderwerp van onderzoek. Tevens wordt gedacht aan mogelijkheden tot korte plaatsing van zonnepanelen (2-3 jaar) in combinatie met een rustperiode voor de grond om organische stof te kunnen opbouwen. In het laatste geval kan bodembiodiversiteit verbeteren.

\section{Koolstof vastleggen in de bodem}

Door grasland minder te scheuren wordt nitraatuitspoeling teruggedrongen, en neemt het stikstof leverend vermogen van de bodem toe. In blijvend grasland (i.e. minstens vijf jaar oud) zorgt een heterogener plantenbestand voor microreliëf waardoor er kleine verschillen in biotoop ontstaan en variatie in grasgroei optreedt. Dit draagt bij aan biodiversiteit door ontwikkeling van insecten, weidevogels, kleine zoogdieren en andere faunasoorten (Korevaar, 2016). Het verminderen van herinzaai kan hier ook aan bijdragen (Zijlstra et al., 2015). Vanuit het oogpunt van biodiversiteit is het bodemecosysteem en de vegetatie na ongeveer 20 jaar een stabiel systeem. Blijvend grasland is minder gevoelig voor extreme neerslag (wat de klimaatbestendigheid verhoogt) doordat het goed bestand is tegen bodemerosie en een goed vochtregulerend vermogen heeft (Kipling et al., 2016). Graslandmanagement kan worden bemoeilijkt door klimaatverandering, bijvoorbeeld omdat het land niet of minder toegankelijk is bij extreme neerslag. Dit kan ook de uitvoering van mitigatiemaatregelen bemoeilijken, zoals het vaker legen van de mestopslag (Massé et al., 2016; Willeghems et al., 2016)

Verslechtering van de grasmat is vaak een symptoom van bodemverdichting en het scheuren van grasland is dan een hersteloperatie daarvoor. Het met zware machines berijden en bewerken van het land onder natte omstandigheden kan bijdragen aan bodemverdichting, waardoor de bodemkwaliteit sterk achteruit gaat en de bodem tevens gevoeliger wordt voor weersextremen, zoals de afvoer van water bij extreme neerslag. Bijna de helft van het landoppervlak in Nederland is gevoelig voor verdichting (Van den Akker et al., 2016).

\section{Gassen afvangen}

Het afvangen van gassen uit mestopslagen en onder dichte vloeren heeft weinig negatieve interactie met andere duurzaamheidsthema's. Het afsluiten van stallen om gassen af te vangen kan vanuit landschappelijk en ethisch oogpunt ongewenst zijn.

\section{Structurele maatregelen}

Een reductie van de omvang van de veestapel reduceert nutriëntenoverschotten en ammoniak uitstoot. Het omzetten van landbouwgrond naar natuur of natte landbouw kan daarnaast gunstig uitpakken voor biodiversiteit. Door verlaging van het melkvolume in Nederland kunnen broeikasgasemissies naar het buitenland verplaatsen. 


\section{Adaptatie}

\subsection{Introductie}

De melkveehouderij is een klimaatgevoelige sector, aangezien veranderingen in het klimaat zowel direct als indirect effect kunnen hebben op de bedrijfsvoering en opbrengsten. In Nederland leidt klimaatverandering tot hogere temperaturen, zachtere en nattere winters, en hetere zomers.

Daarnaast zullen weersextremen, zoals langdurige droogte, hittegolven, en extreme neerslag, steeds vaker voorkomen en tot meer schade leiden dan voorheen. Ook indirect kunnen deze veranderingen in klimaat gevolgen hebben, zoals veranderingen in ziekten en plagendruk, fluctuaties in marktprijzen, en een stijgende zeespiegel en geassocieerde verzilting.

\section{Klimaatverandering}

Om klimaatverandering inzichtelijk te maken heeft het KNMI vier klimaatscenario's ontwikkeld, welke mogelijke richtingen aangeven waarin het klimaat in Nederland zich in de komende decennia kan ontwikkelen. De hoofdlijn van alle scenario's is dat het gemiddeld warmer wordt en dat de gemiddelde neerslag toe zal nemen. Ook zal de $\mathrm{CO}_{2}$ concentratie in de lucht stijgen, en veranderingen optreden in bewolking, luchtvochtigheid en wind. Veranderingen zullen een toename in weersextremen tot gevolg hebben. De vier scenario's verschillen in de mate waarin het warmer wordt (Gematigd of Warm; Figuur 5) en hoe de neerslag verdeling over het jaar is (Hoge of Lage verandering in luchtstromingspatroon).

Gedetailleerde omschrijvingen van klimaatscenario's zijn beschikbaar op de website van het KNMI

(http://www.klimaatscenarios.nl).

\section{Nationale klimaatadaptatiestrategie}

Landbouw is één van de 9 sectoren in de Nationale Klimaatadaptatie Strategie (NAS, 2016). In het Uitvoeringsprogramma Klimaatadaptatie is de koers voor klimaatadaptatie in Nederland uitgezet (NAS, 2018). Frequentere oogstschade en beschadiging van productiemiddelen in de land- en tuinbouw door extreem weer is bestempeld tot één van de zes meest urgente ${ }^{10}$ effecten van klimaatverandering in de NAS. Extra bodemdaling en verzilting worden op termijn urgent (NAS, 2016).

\footnotetext{
${ }^{10}$ Het PBL heeft 5 criteria gebruikt om urgentie te bepalen: waarschijnlijkheid dat het effect optreedt, mogelijke impact, mate van onzekerheid, adaptatiecapaciteit van de sector, en duur van benodigde investeringen.
} 


\subsection{Gevolgen van klimaatverandering voor de melkveehouderij}

Auteur: Marion de Vries (Wageningen Livestock Research)

\section{Uitdagingen omtrent onderzoek naar effecten van klimaatverandering}

Onderzoek naar effecten van klimaatverandering in de Nederlandse landbouw heeft zich tot dusver met name op de akkerbouw gericht. De melkveehouderij onderscheidt zich van akkerbouwsectoren vanwege andere teelten, activiteiten en biologische processen, en additionele klimaatrisico's rondom het houden van dieren (bijv. dierziekten, diergezondheid en welzijn, voerprijzen). Zo zijn melkveehouders met beweiding bijvoorbeeld afhankelijker van korte termijn variaties in grasgroei en graskwaliteit. Daarnaast hebben variaties in klimaat en weersextremen zoals droogte en wateroverlast niet alleen invloed op totaalopbrengsten maar ook op dagelijkse beslissingen van veehouders, zoals beweiden/opstallen, maaien, en voerregimes.

Het voorspellen van de gevolgen van klimaatverandering voor de melkveehouderij is complex. Dit begint bij klimaatscenario's welke een grote mate van onzekerheid kennen, met name wat betreft de frequentie en aard van weersextremen. Studies waarin effecten van klimaatverandering en adaptatiemaatregelen worden gekwantificeerd worden veelal gedaan op basis van gewasgroeimodellen en statistische modellen om effecten op opbrengsten en inkomen te schatten. Een dergelijke aanpak kan echter onvoldoende de effecten van klimaatverandering en adaptatiemaatregelen voorspellen, omdat: i) onderzoek vaak op gewasniveau plaatsvindt (versus bedrijfs- of regionaal niveau), ii) de context van andere ontwikkelingen niet wordt meegenomen (zoals technologische ontwikkeling, wet en regelgeving, marktprijzen), iii) effecten van klimaatextremen en ziekten en plagen niet worden meegenomen, en iv) een beperkt aantal adaptatiemaatregelen kan worden geanalyseerd (Reidsma et al., 2015). Van andere factoren, zoals technologische ontwikkeling, beleid en marktontwikkeling, wordt verwacht dat ze meer invloed zullen hebben op de ontwikkeling en prestaties van bedrijfssystemen dan klimaatverandering (Ewert et al., 2005; Hermans et al., 2010; Paas et al., 2016). Wanneer deze factoren niet worden meegenomen worden vaak te pessimistische conclusies getrokken over effecten van klimaatverandering, terwijl vaak te optimistische conclusies worden getrokken wanneer klimaatextremen en ziekten/plagen niet worden meegenomen (Reidsma et al., 2015; Paas et al., 2016).

Gevolgen van klimaatverandering voor de melkveehouderij

Voor de melkveehouderijsector kan klimaatverandering gevolgen hebben voor:

- gras- en gewasproductie

- ziekten en plagen in planten en dieren

- diergezondheid, productiviteit, en welzijn

- $\quad$ prijzen van grondstoffen en zuivel

- $\quad$ productiemiddelen (bijv. land, water, machines, gebouwen)

- bedrijfsvoering (bijv. beweiding, timing maaien, voerregimes)

De gevolgen van klimaatverandering kunnen zowel positief als negatief zijn. Zo zullen de hogere temperaturen en stijging in $\mathrm{CO}_{2}$ concentratie naar verwachting gunstig uitpakken voor gras- en maïsopbrengsten, en kan dit tevens kansen bieden aan de teelt van nieuwe gewassen. Anderzijds zullen weersextremen - zoals hittegolven, langdurige droogte, en wateroverlast - vooral negatieve gevolgen hebben voor bedrijfsvoering en productiviteit.

Tot op heden zijn in Nederland slechts enkele studies gedaan waarin effecten van klimaatverandering op integrale wijze zijn geanalyseerd (d.w.z. op bedrijfsniveau, incl. sociaaleconomische ontwikkelingen en klimaatextremen). In een studie van Schaap et al. (2014) is een semi-kwantitatieve participatieve 
aanpak gebruikt waarin samen met boeren effecten van klimaatverandering (incl. extremen) en mogelijke adaptatiemaatregelen zijn geïdentificeerd. In deze studie wordt aangegeven dat door verlenging van het groeiseizoen grasopbrengsten fors kunnen stijgen in het scenario voor matige klimaatverandering (G scenario), en, o.a. door droogte, licht kunnen dalen in het scenario voor snelle klimaatverandering ( + scenario; Paas, 2013). De toename in het aantal hete dagen (>30 graden) wordt als een belangrijk klimaatrisico gezien voor grasopbrengsten. Voor mais wordt een toename in productie verwacht van $9 \%$ in het G scenario en $1 \%$ in het $W+$ scenario (Wolf et al., 2010). Uit een modelstudie van Paas et al. (2016) voor melkveebedrijven op zand in de Baakse Beek blijkt dat stijgingen in temperatuur en $\mathrm{CO}_{2}$ concentraties waarschijnlijk een positief effect hebben op het bruto bedrijfsresultaat in 2050. Hierin zijn weersextremen en scenario's voor klimaatverandering, technologie-, beleid- en marktontwikkeling meegenomen. Weersextremen in het scenario voor snelle klimaatverandering $(\mathrm{W}+)$ konden dit positieve effect echter flink afzwakken of teniet doen (gemiddeld $15 \%$ lager bedrijfsresultaat), en technologie-, beleid- en prijsontwikkelingen hadden een grotere invloed op het uiteindelijke bedrijfsresultaat dan klimaatverandering. Zowel inschattingen van effecten van weersextremen als sociaaleconomische scenario's zijn hoogst onzeker.

Wat betreft prijzen van zuivelproducten en grondstoffen kunnen effecten van klimaatverandering elders in de wereld tot prijsstijgingen of schaarste in de aanvoer van grondstoffen leiden, zoals soja voor veevoer. Door zijn relatief grote soja-import is Nederland hier van alle EU-lidstaten het meest kwetsbaar voor (PBL, 2015b). Anderzijds kan klimaatverandering ook zorgen voor een relatief concurrentievoordeel voor de Nederlandse melkveehouderijsector t.o.v. andere landen, wanneer klimaatverandering elders slechter uitpakt dan in Nederland. Wanneer wereldwijde broeikasgasemissies niet sterk worden teruggebracht is de verwachting dat een langdurige droogte met schadelijke gevolgen voor de landbouw in Europa in 2050 tot eens per twee jaar zal voorkomen (PBL, 2015a).

\section{Invloed van locatie en bedrijfstype}

Effecten van klimaatverandering zijn sterk afhankelijk van locatie en bedrijfstype. Wat betreft bedrijfstype zijn volgens Schaap et al. (2014) bedrijven kwetsbaarder naarmate ze meer gespecialiseerd zijn. Volgens Paas et al. (2016) kunnen middelgrote bedrijven zich beter aanpassen aan klimaat- en sociaaleconomische verandering dan grote bedrijven, omdat middelgrote bedrijven nog niet optimaal efficiënt opereren en dus ruimte voor verbetering hebben i.t.t. grotere bedrijven. Verwacht wordt dat grote bedrijven meer baat hebben bij nieuwe technologische ontwikkelingen.

Wat betreft de locatie zijn voor bepaalde regio's en grondsoorten specifieke effecten van klimaatverandering te verwachten - zoals zandgrond (gevoelig voor droogte), veenweidegebieden (versnelde veenafbraak door klimaatverandering), rivierengebieden (wateroverlast) - maar kunnen er ook grote verschillen zijn binnen een regio, en zelfs binnen een bedrijf of perceel. Bedrijfstype en locatie hebben derhalve grote invloed op klimaatbestendigheid van bedrijven en is bepalend voor geschikte adaptatiemaatregelen. Om beter zicht te krijgen op specifieke risico's en adaptatiemaatregelen voor diverse locaties en bedrijfstypen is meer onderzoek nodig.

\section{Inschatten van klimaatrisico's}

Kennis over de kans op voorkomen van klimaateffecten kan de sector concurrentievoordelen opleveren wanneer ze dit vertaalt in gerichte investeringen en bedrijfsstrategieën (Schaap et al., 2014). Voor de melkveehouderij is hier een eerste aanzet toe gedaan door Schaap et al. (2014), en meer systematisch voor de landbouw in zijn algemeenheid door het PBL (2015a). Zoals reeds beschreven is het inschatten van risico's echter complex. Ook kan de schade door klimaatextremen 
gemiddeld gezien weliswaar beperkt blijven, maar kunnen kosten hoog oplopen voor individuele bedrijven.

Het PBL (2015a) schat de kans groot dat weersextremen in de komende decennia oogstschade veroorzaken in de landbouw (Tabel 3). Ook is het waarschijnlijk dat door weersextremen de elektriciteit uitvalt. De kans op (dierlijke/plantaardige) ziekten en plagen wordt kleiner ingeschat, maar als het zich voordoet kan de schade groot zijn.

Tabel 3 Economische impact van klimaatverandering (PBL, 2015; alleen voor landbouw relevante risico's getoond).

\begin{tabular}{|c|c|c|c|}
\hline \multirow[t]{2}{*}{ Schade } & \multicolumn{3}{|l|}{ Kans op voorkomen } \\
\hline & $\begin{array}{l}\text { Waarschijnlijk, dit } \\
\text { decennium }\end{array}$ & Waarschijnlijk, deze eeuw & $\begin{array}{l}\text { Onwaarschijnlijk, deze } \\
\text { eeuw }\end{array}$ \\
\hline Groot & & $\begin{array}{l}\text { Oogstschade door elkaar } \\
\text { opvolgende droogteperiodes, } \\
\text { schade aan gebouwen door extra } \\
\text { bodemdaling, uitval cruciale } \\
\text { delen } \\
\text { elektriciteitsnetwerk door } \\
\text { langdurige hitte/droogte of } \\
\text { windstilte }\end{array}$ & $\begin{array}{l}\text { Oogstschade door plaag } \\
\text { of dierziekte, } \\
\text { overstroming door } \\
\text { bezwijken primaire } \\
\text { waterkering, } \\
\text { overstroming in } \\
\text { Oost-Nederland door } \\
\text { dijkdoorbraak in } \\
\text { Duitsland }\end{array}$ \\
\hline Middelgroot & $\begin{array}{l}\text { Verkeershinder door } \\
\text { extreme } \\
\text { windstoten en regenval }\end{array}$ & $\begin{array}{l}\text { Oogstschade door } \\
\text { weersextremen, overstroming } \\
\text { door bezwijken secundaire } \\
\text { waterkering, prijsstijging voedsel } \\
\text { door langdurige droogte in } \\
\text { Europa, lokale uitval } \\
\text { elektriciteitsvoorziening } \\
\text { door weersextremen }\end{array}$ & \\
\hline Klein & $\begin{array}{l}\text { Lokale wateroverlast } \\
\text { door extreme regenval, } \\
\text { prijsschommelingen } \\
\text { grondstoffen. }\end{array}$ & & \\
\hline
\end{tabular}

In de hierop volgende hoofdstukken is uitgewerkt wat mogelijke effecten van klimaatverandering zijn voor de deelonderwerpen gras en gewas, gewasbescherming, en diergezondheid en welzijn. Ook wordt ingegaan op waterhuishouding, welke een belangrijke rol speelt in effecten van klimaatextremen. Zoals hierboven vermeld kan klimaatverandering ook gevolgen hebben voor prijzen van zuivel en grondstoffen (bijv. geïmporteerd veevoer), productiemiddelen (bijv. land, water, machines, gebouwen), en bedrijfsvoering (bijv. beweiding, timing maaien, voerregimes). In deze studie wordt op deze thema's niet ingegaan omdat dit buiten de afbakening van het onderzoek viel.

\subsubsection{Gras en gewas}

Auteur: Jantine van Middelkoop (Wageningen Livestock Research)

De ruwvoervoorziening in de Nederlandse melkveehouderij is op dit moment voornamelijk gebaseerd op grasland en snijmaïs. Klimaatverandering zal invloed hebben op de teelt van deze gewassen. Om een inschatting te maken van mogelijke toekomstige ontwikkelingen is informatie op een rij gezet 
over de impact die klimaatverandering kan hebben op grasland en snijmaïs. Effecten die specifiek aan waterbeheer gekoppeld zijn, zijn beschreven in paragraaf 3.2.4.

De impact van klimaatverandering op gewasgroei en -kwaliteit is een gevolg van een aantal weerfactoren. Belangrijke weerfactoren zijn (Gauly et al., 2013): een hogere lucht temperatuur, verlenging van het groeiseizoen, veranderende neerslagpatronen met periodes van extreme neerslag en langere periodes van droogte, en een hogere concentratie $\mathrm{CO}_{2}$ in de lucht. De weersveranderingen zijn niet onafhankelijk. Zo gaat droogte in de zomer vaak gepaard met hoge temperaturen maar hoeft de temperatuur niet sterk te veranderen ten opzichte van het huidige patroon wanneer er veel neerslag valt. Een weerfactor kan soms op meerdere manieren invloed hebben in de productie van gewassen. Zo kan een weerfactor naast de invloed op productie van grasland ook invloed hebben op voederkwaliteit en de mogelijkheden voor gebruik.

De verwachting is dat als de frequentie van extreme klimaatgebeurtenissen niet of weinig verandert ('moderate warming'), de opwarming in de eerste helft van deze eeuw de gewas- en graslandopbrengst in gematigde regio's zoals Nederland zal verhogen (Izaurralde et al., 2011). Daarnaast zal de invloed van de klimaatverandering zich manifesteren in het toenemen van weersextremen: langere perioden van droogte en perioden van wateroverlast. De perioden van droogte zullen waarschijnlijk gepaard gaan met hoge temperaturen. Er wordt verwacht dat deze weersextremen een deel van het positieve effect teniet doen (Schaap et al., 2014; Paas et al., 2016).

Verschillende gewassen zullen in verschillende mate reageren op de veranderingen in het klimaat. Belangrijk zijn verschillen in de manier waarop de fotosynthese plaatsvindt. Verschillen in type fotosynthese zijn aangeduid in C3- en C4-planten. C3-planten (zoals gras) zijn aangepast aan een gematigd klimaat: ze beginnen bij een lagere temperatuur te groeien, maar zijn minder efficiënt met water. C4-planten (zoals maïs) zijn aangepast aan een tropisch klimaat: ze starten de groei bij een relatief hoge temperatuur en zijn efficiënter met water dan $\mathrm{C} 3$-planten. Een verhoogde $\mathrm{CO}_{2}$ concentratie verhoogt de fotosynthese snelheid in C3 soorten maar in C4 soorten is dat effect minder aanwezig (Hopkins and Del Prado, 2007; Izaurralde et al., 2011; Gauly et al., 2013). De respons van C3 soorten op $\mathrm{CO}_{2}$ wordt kleiner wanneer de temperatuur toeneemt. C4-planten profiteren echter meer van de hogere temperaturen en kunnen (theoretisch) beter omgaan met een reductie van het beschikbare vocht.

Klimaatverandering zal naar verwachting leiden tot grotere verzilting in de zomer, waar waarschijnlijk landbouwers in Zuid-Holland het meeste last van ondervinden vanwege onvoorspelbaarheid en onbeheersbaarheid (De Boer and Radersma, 2011). Ten opzichte van andere sectoren heeft de melkveehouderij relatief weinig last van verzilting: zowel gras als koeien kunnen chloridegehalten tot 2700 mg/l goed verdragen. De teelt van snijmaïs leidt schade bij gehalten vanaf 700 tot $800 \mathrm{mg} / \mathrm{l}$, en zal daarom eerder schade ondervinden.

\section{Gras}

Grasland in NW Europa bestaat voornamelijk uit C3-planten. Voor grasland worden de verwachte effecten van klimaatverandering in NW Europa op dit moment veelal kwalitatief geduid (Hopkins and Del Prado, 2007). Paas et al. (2016) hebben kwantitatieve schattingen gedaan van de effecten op gewasproductie, en die in bedrijfsverband geplaatst.

Mogelijke positieve effecten van klimaatverandering zijn: 
- Toename van de groei/bruto productie van grasland door toename van de $\mathrm{CO}_{2}$-concentratie en temperatuur, en door een langer groeiseizoen als gevolg van de hogere temperatuur in het najaar;

- $\quad$ Een hogere water efficiëntie van gewassen door toename van de $\mathrm{CO}_{2}$-concentratie;

- $\quad$ Een hogere temperatuur kan de mineralisatie stimuleren waardoor er sneller nutriënten vrijkomen uit organische stof, mits er voldoende vocht aanwezig is.

Mogelijke negatieve effecten zijn:

- $\quad$ Langere periodes van droogte in de zomer zullen vaker vóórkomen. In het ergste geval kan langdurige droogte het positieve effect op droge stofproductie overtreffen;

- In Nederland gaat droogte vaak gepaard met hitte. Bij hoge temperaturen (boven ca. 25-27

${ }^{\circ} \mathrm{C}$ ) stoppen C3-gewassen zoals Engels raaigras met produceren van biomassa. Wanneer dit lang aanhoudt sterft de bladmassa van gras af en gaat het in rust om pas weer te gaan groeien als de temperatuur daalt en er weer voldoende neerslag valt;

- $\quad$ Bij toenemende temperatuur veroudert het gewas sneller en daalt de verteerbaarheid sneller in de tijd.

- Toename van uitspoeling door toenemende regenval in de winter. Potentieel is er wel een hogere stikstofefficiëntie in de winter te verwachten door groeiend gras en vee;

- Minder gelegenheid voor begrazing en oogsten op nattere gronden door periodes van extreme neerslag.

Effecten die zowel positief als negatief kunnen uitwerken:

- Veranderingen in voerkwaliteit. Verwacht wordt dat het gras hogere concentraties van wateroplosbare koolhydraten en lagere N/eiwit concentraties zal bevatten bij gelijkblijvende droge stofopbrengst.

- Wanneer de botanische samenstelling van grasland verschuift, zal de voerkwaliteit veranderen. Bij een toename in het aandeel vlinderbloemigen stijgt bijvoorbeeld het eiwitgehalte van het geoogste ruwvoer. Of een verandering in kwaliteit of botanische samenstelling positief of negatief uitwerkt, is sterk afhankelijk van de situatie van het melkveebedrijf in de toekomst. Op dit moment is voor bedrijven met een groot aandeel gras in het rantsoen verlaging van de N/eiwit concentratie positief omdat er nu meer dan voldoende eiwit aangevoerd kan worden. Met de toekomstige plannen voor meer eiwit van eigen land en de negatieve effecten als snellere veroudering van het gewas, is het mogelijk dat in de toekomst een hogere eiwitproductie gewenst is.

Maïs

Maïs (C4-gewas) zal naar verwachting in eerste instantie minder last hebben van droogte hebben en meer profiteren van de hogere temperaturen dan permanent grasland. Omdat maïs dieper wortelt zal het bij extreme droogte langer water uit diepere grondlagen kunnen halen. Wanneer het echter zo lang droog is dat de hele watervoorraad verbruikt is, zal ook maïs last van droogte krijgen en de opbrengst dalen. Bovendien is het bij maïs van belang op welk moment van de teelt de droogte intreedt: droogte bij kolfzetting zorgt voor een lager kolfaandeel en daarmee ook een lagere voederwaarde. Dit herstelt niet, ook niet als er later weer voldoende neerslag valt. Mogelijk dat afwisseling van droge en natte periodes en de volgorde daarvan ook invloed heeft op het effect op productie, zoals dat bij grasland het geval lijkt te zijn. Maïs kan echter slecht tegen wateroverlast en (te) lage temperaturen.

Verlenging van het groeiseizoen zou voor zowel C3 als C4 planten voordelig kunnen zijn maar is waarschijnlijk niet direct voordelig voor de productie van gewassen die één seizoen groeien 
(akkerbouwgewassen; Gauly et al. 2013). De mogelijkheid voor meerdere teelten per jaar kan toenemen.

\subsubsection{Gewasbescherming}

Auteur: Rommie van der Weide (Wageningen Plant Research)

Een veranderend klimaat heeft niet alleen effect op de potentiële opbrengsten van de gewassen maar ook op de beperkende factoren die voorkomen dat potentiële opbrengsten gerealiseerd worden. In dit hoofdstuk wordt in kaart gebracht wat het effect van klimaatverandering kan zijn op achtereenvolgens ziekten, plagen, onkruiden en andere factoren met een duidelijke relatie met gewasbescherming. In Bijlage 2 is meer gedetailleerde informatie per gewas opgenomen.

Om de gewasbeschermingsproblematiek bij de verschillende klimaatscenario's in kaart te brengen is het nuttig om in kaart te brengen wat de problemen en de maatregelen zijn in de regio's zijn waar het klimaat nu vergelijkbaar is met ons toekomstige klimaat. Het KNMI geeft aan dat we rond 2050 een klimaat hebben dat vergelijking vertoont met het klimaat rond Nantes-Bordeaux in Frankrijk of noordcentraal Italië (http://www.klimaatscenarios.nl/toekomstig_weer/images/

Amsterdam_2050_w470.png; november 2016). Eerdere studies aangehaald door Riemens (2012) verwachtten in Nederland in 2050 een klimaat zoals momenteel rond Parijs en in 2080 in centraal Italië.

\section{Ziekten}

Door veranderingen in het klimaat wordt verwacht dat schimmelziekten eerder in het seizoen in het gewas komen. Bij de zachtere winters overleven meer pathogenen (Juroszek and von Tiedemann, 2015). Aan de andere kant zal een aantal ziekten zich in de zomer minder kunnen ontwikkelen wanneer het warmer en droger is, met sterkere wisselingen t.o.v. koudere en nattere zomers. Er worden meer en vroegere problemen met bladschimmels verwacht. Ook de toename in bladmassa door meer $\mathrm{CO}_{2}$ resulteert in een gunstiger klimaat voor de bladschimmels. Het effect hiervan wordt weer gereduceerd door minder huidmondjes en daarmee infectiepoorten in de bladeren voor sommige schimmels (West et al., 2012). De besmetting met schimmels die mycotoxinen in het geoogste product geven, nemen naar verwachting toe (Schaap et al., 2011; Van der Fels-Klerx et al., 2012; Lamichhane et al., 2015; Newbery et al., 2016). Tenslotte kunnen aanpassingen in het teeltsysteem die gericht zijn op adaptatie voor de klimaatproblemen zoals niet kerende grondbewerking, extra problemen met schimmelziekten geven. Bij een snellere kieming en begingroei van de gewassen hebben deze naar verwachting minder problemen met kiemschimmels.

Virussen kunnen eerder in het seizoen tot expressie komen en tot grotere schade leiden met name doordat de besmetting met insecten vaak eerder plaatsvindt (West et al., 2012; Lamichhane et al., 2015). Een aantal bacterieziekten lijken in het Zuiden van Europa een grotere rol te spelen (West, 2012).

Verder is er wetenschappelijk onderzoek gaande waarin gemeld wordt dat voor mens en dier ziekteverwekkende bacteriën via rhizosfeer en de mest mogelijk in de planten kunnen komen. Deze bacteriën kunnen daarmee een infectiebron zijn en een extra risico t.a.v. de resistentieontwikkeling tegen antibiotica (Lamichhane, 2015). Het is onduidelijk in hoeverre klimaatverandering hier effect op heeft, maar mitigerende maatregelen zoals mestvergisting zouden hier wel een effect op kunnen 
hebben bijvoorbeeld door doding van deze bacteriën tijdens vergisting (mondelinge communicatie Overbeek, 2016).

\section{Plagen}

Insecten zijn koudbloedige dieren, die direct reageren op omgevingstemperatuur. Dit houdt in dat ze eerder ontwaken bij hogere temperatuur, sommige soorten extra levenscycli binnen hetzelfde jaar kunnen afronden en hogere plaagdichtheden bereikt kunnen worden (Leisova-Svobodova et al., 2012; Lamichhane et al., 2015). Door zachtere winters kunnen een aantal plaaginsecten overleven onder onze omstandigheden die dat voorheen niet konden. Een aantal plagen zal daardoor oprukken naar onze omgeving. Het is daarbij de vraag in hoeverre de natuurlijke bestrijders van deze plagen in gelijke tred zich ook naar het Noorden verplaatsen. Ook zijn er mogelijke verschillen in de fenologie. Daarom is het mogelijk dat nieuwe plagen zich sneller ontwikkelen en meer schade veroorzaken.

Vickers en Berry (2009) verwachten meer problemen in ruwvoerdergewassen met vooral stengelaaltjes, t.g.v. meer cycli bij warmer weer. Deze soorten veroorzaken o.a. omvalziekten in mais met name bij relatief nat voorjaarsweer (Caubel and Rivoal, 1972; Hirling, 1974). Ook kan extra vermeerdering van aaltjes (berucht is Pratylenchus penetrans) in ruwvoerdergewassen die hier zelf weinig last van hebben, wel voor problemen in andere gewassen zorgen. De veredeling van ruwvoergewassen gericht op een specifieke aaltjesresistentie kan juist kansen bieden voor opname van deze gewassen in akkerbouwrotaties. De resistente ruwvoergewassen kunnen als saneringsmaatregel in akkerbouwrotaties worden ingepast. Leguminosen zoals klavers hebben vaak wel last van aaltjes zodat ze eerder uit de grasmat verdwijnen (mondelinge communicatie Leendert Molendijk, 2016).

\section{Onkruiden}

De opkomst van onkruiden is eerder en duurt bij een aantal soorten minder lang (Riemens, 2012). Onkruiden groeien sneller in het voorjaar waardoor er meer opbrengstreductie van het gewas optreedt indien de onkruiden laat bestreden worden. Het gewas zal waarschijnlijk ook sneller groeien waardoor er minder ruimte is voor concurrentie door late kiemers.

Een aantal onkruidsoorten die hier t.g.v. koudere winters niet konden overleven zullen in de toekomst wel een kans krijgen. Ook neemt de mogelijkheid toe dat er meer problemen komen met opslag uit gewassen (Van de Wiel et al., 2011).

De mechanische bestrijding van onkruiden staat voor een extra uitdaging omdat de onkruiden sneller groeien en er langere perioden met natte grond verwacht worden. De meer gangbare mechanische beheersing richt zich op klein éénjarig onkruid op relatief droge grond. Ook kan de onkruidproblematiek zich verergeren bij adapterende maatregelen zoals niet kerende grondbewerking.

\section{Andere factoren belangrijk voor de gewasbescherming}

Een belangrijke opbrengstdrukkende factor voor gewassen in Nederland met een relatie met klimaatverandering is de bodemverdichting. Meer dan $45 \%$ van het grondoppervlak in Nederland is verdicht (Van den Akker et al., 2016). Volgens de experts geeft dit nu al een gemiddeld opbrengstverlies van $10 \%$ met incidenteel verliezen groter dan $35 \%$ t.g.v. meer problemen met droogte of wateroverlast. De verwachting is dat met de voorziene klimaatveranderingen deze problemen zullen verergeren.

Deze bodemverdichting, de effecten ervan en de eventuele maatregelen die hiertegen genomen zouden kunnen worden, hebben vele consequenties en raakvlakken met de gewasbescherming in voedergewassen. Vernatting geeft grotere problemen met o.a. een aantal onkruiden, slakken en 
mycotoxinen producerende schimmels (Kempenaar, 2003). Berijden en bewerking van het veld onder natte omstandigheden (zou) beperkt moeten worden, wat de beheersingsmethoden direct beïnvloedt (West, 2012). Verandering van teeltmethoden gericht op vermindering van de verdichting kan zowel verergering als ook verlichting van de gewasbeschermingsdynamiek en problematiek geven.

Er zijn een aantal rapporten onder andere van de FAO verschenen over het effect van de klimaatverandering op de bestuivers van gewassen (Kjøhl et al., 2011; Potts et al., 2016). Vijfendertig procent van de wereldvoedselproductie is direct afhankelijk van de bestuiving van de gewassen door met name insecten. Men maakt zich zorgen over de effecten van klimaatverandering (te hoge temperaturen, onvoldoende snelle aanpassing e.a.), intensivering van de landbouw en pesticiden gebruik op de bestuivers. De voor ruwvoeder gebruikte oliehoudende gewassen zoals kool zaad en diverse leguminosen zijn afhankelijk van een effectieve bestuiving. Anticiperende maatregelen hebben een directe relatie met de gewasbescherming zowel t.a.v. de beschikbaarheid van beheersingsmaatregelen van plagen als wel eventuele veranderingen in teeltsystemen en diversificatie.

\subsubsection{Diergezondheid en welzijn}

Auteur: Jan ten Napel (Wageningen Livestock Research)

Gezondheidsaantastingen ontstaan in de wisselwerking tussen dier, leefomgeving en, in het geval van infectieuze dierziekten, één of meerdere ziekteverwekkers. In een stabiele leefomgeving zijn dieren door natuurlijke selectie en eerdere blootstelling enigszins voorbereid en blijven de gevolgen beperkt. In een veranderende omgeving zoals het geval is bij klimaatverandering zijn populaties en individuele dieren niet noodzakelijk optimaal voorbereid op de bedreigingen in de nieuwe situatie. Ook voor de veehouder en de dierenarts betekent een veranderende omgeving dat bestaande kennis mogelijk niet toereikend is. Het doel van dit hoofdstuk is om in grote lijnen te schetsen hoe klimaatverandering in Nederland op termijn de gezondheid en het welzijn van dieren in de melkveehouderij zou kunnen beïnvloeden.

De potentiële effecten van klimaatverandering op gezondheid en welzijn van melkvee zijn vooral indirect. Klimaatverandering en menselijke activiteit, al dan niet in reactie op klimaatverandering, veranderen samen de natuurlijke en aangelegde omgeving van de melkveehouderij en beïnvloeden de gezondheid en welzijn van melkvee op uiteenlopende manieren (Lubroth, 2012). Het is dus moeilijk om aan te geven wat er precies gaat gebeuren, omdat klimaat niet het enige is dat verandert.

In de literatuur gaat het dan ook vooral over het effect van klimaatverandering op ziekte-ecologie en de dynamiek van overdracht van ziekteverwekkers. In deze paragraaf onderscheiden we infectieuze ziekteverwekkers, parasieten en niet-infectieuze aantasting van gezondheid en welzijn.

\section{Ziekteverwekkers}

Micro-organismen die pathogeen kunnen zijn voor melkvee kunnen op veel verschillende manieren worden ingedeeld. De invloed van klimaatverandering lijkt vooral samen te hangen met de manier van verspreiding en overdracht van de ziekteverwekker. De periode dat ziekteverwekkers blootstaan aan de omstandigheden buiten het lichaam van de gastheer is belangrijk in dit opzicht (Lubroth, 2012).

Ziekteverwekkers die zich via lucht, aerosol of materialen verspreiden van dier naar dier en van bedrijf naar bedrijf zouden kunnen profiteren van milde en natte winters. Bij gevoeligheid voor uv-licht gaat de ziektedruk in een droge en hete zomer juist weer omlaag. Voor het Influenza virus is 
bijvoorbeeld bij cavia's waargenomen dat de verspreiding toeneemt bij zowel lage (5 graden Celsius) als hoge temperaturen (30 graden Celsius), maar dat dit niet verklaard kan worden door de immuunrespons (Lowen et al., 2007).

Als dier-dier contact de belangrijkste bron van besmetting is dan lijkt de invloed van klimaatverandering beperkt. Een uitzondering is als klimaatverandering leidt tot migratie of verandering van migratiepatronen van dieren in het wild. Bijvoorbeeld in een koude winter is de hoeveelheid open water beperkt en is de dichtheid van watervogels op die plaatsen veel hoger dan in een milde winter, waardoor de verspreiding van ziekteverwekkers onder watervogels groter is (Ottaviani et al., 2010). Contact tussen wilde dieren en runderen op het melkveebedrijf zou kunnen leiden tot een besmetting met een ziekteverwekker die voor de dieren nog onbekend is.

Micro-organismen die vooral in grond of in de leefomgeving van de dieren voorkomen en soms pathogeen zijn of juist een bedreiging voor de humane gezondheid vormen, profiteren vaak van een combinatie van hoge luchtvochtigheid en hoge temperatuur voor snellere vermeerdering. In een Italiaans onderzoek werd een ongunstige relatie gevonden tussen een index van temperatuur en luchtvochtigheid aan de ene kant en celgetal en kiemgetal in tankmelk aan de andere kant, maar alleen bij hogere waarden van de index van temperatuur en luchtvochtigheid (Bertocchi et al., 2014). Tijdelijke overstromingen als gevolg van extreme neerslag kunnen verder verontreinigd water over een groot oppervlak verspreiden, waardoor de kans op infectie toeneemt.

Micro-organismen die via een vector verspreiden (zoals vliegen, muggen, knutten, teken) kunnen op verschillende manieren profiteren van de verwachte klimaatverandering. Hoge intensiteit van de neerslag in de zomer zal extra biotopen genereren voor muggenlarven. Een hogere temperatuur zorgt er voor dat spinachtigen gemakkelijker geïnfecteerd raken met een micro-organisme, dat het microorganisme beter overleeft en dat het gemakkelijker weer wordt afgegeven door de vector. Bij hogere temperatuur en luchtvochtigheid kan het leefgebied van de vectoren zich ook sneller uitbreiden, zoals is gebeurd met het blauwtongvirus. Van dit virus wordt aangenomen dat klimaatverandering verantwoordelijk is voor de regionale veranderingen door de impact op muggensoorten die vector zijn (Maclachlan et al., 2015). Dezelfde vector-pathogeen combinaties kunnen ook populaties dieren die in het wild leven aantasten en zo een reservoir voor de ziekteverwekker creëren.

\section{Parasieten}

De verwachting is dat vooral koudbloedige diersoorten beïnvloed worden door temperatuurstijging bij klimaatverandering. Alle parasieten van rundvee vallen in deze categorie:

- Endoparasieten leven het grootste deel van hun leven in het lichaam van de gastheer. Voorbeelden zijn maagdarmwormen, eencelligen en longwormen. Ze verspreiden zich via eitjes of cysten in de ontlasting naar andere gastheren. Soms gebruiken ze hiervoor een tussengastheer, zoals de leverbot die een poelslak als tussengastheer gebruikt. De overleving buiten het lichaam van de gastheer en de infectie van nieuwe (tussen)gastheren is beter bij hogere omgevingstemperaturen en voldoende vocht voor platwormen (Mas-Coma et al., 2009) en rondwormen (Verschave et al., 2016).

- Ectoparasieten zijn stekende of bloedzuigende insecten, mijten en teken. Klimaatverandering kan leiden tot een verandering van de verhoudingen tussen soorten organismen in een ecosysteem waardoor de overlast van bepaalde soorten vliegen, horzels en muggen sterk kan veranderen. 
Niet-infectieuze aantasting

Klimaatverandering kan ook rechtstreeks de gezondheid en het welzijn van dieren in de melkveehouderij aantasten. Bijvoorbeeld als droogte in combinatie met zeespiegelstijging leidt tot verzilting en het zoutgehalte van het drinkwater te snel toeneemt of te hoog wordt, krijgt het dier last van uitdroging. Een dier krijgt last van hittestress als de warmteafgifte onvoldoende dreigt te worden en de lichaamstemperatuur gaat oplopen. Bij hete zomers of bij warme en vochtige zomers zal dit vaker gebeuren. Koeien met een hoge melkgift hebben hier sneller last van dan niet-producerende dieren (droogstaande koeien en jongvee; Das et al., 2016). Voor Holstein koeien ligt de bovenste kritische temperatuur van de thermoneutrale zone tussen $20^{\circ} \mathrm{C}$ en $24^{\circ} \mathrm{C}$. Recent onderzoek laat zien dat hittestress invloed heeft op melkproductie, melksamenstelling, (uier)gezondheid, vruchtbaarheid, voeropname en gedrag van koeien (Timmerman et al., 2018). In deze studie zijn indicatieve kortetermijn kosten van een jaar met relatief veel warme dagen geschat op circa $€ 5.600$ voor een bedrijf met 100 koeien. Hierin zijn lange-termijn effecten echter niet meegenomen, zoals effecten op vruchtbaarheid en gezondheid.

Omdat de gemiddeld hogere temperatuur ervoor kan zorgen dat de voeropname achter blijft bij de behoefte van de dieren, vooral in de piek van de lactatie, neemt de kans op metabole stress ook toe als gevolg van de klimaatverandering. Dieren die last hebben van uitdroging, hittestress of metabole stress zijn op dat moment vatbaarder voor infecties, omdat de stress respons leidt tot een tijdelijke onderdrukking van een immuunrespons (Das et al., 2016).

Het veranderende ecosysteem kan ook tot gevolg hebben dat planten met giftige stoffen, zoals blauwzuurverbindingen, algemener worden. Met name bij overvloedige regen na ernstige droogte kan blauwzuur vrijkomen. Herkauwers zijn relatief gevoelig voor blauwzuur en zullen dan mogelijk vergiftigingsverschijnselen vertonen. Een andere mogelijke oorzaak van vergiftiging is botulisme bij langdurig hoge temperaturen.

\subsubsection{Waterbeheer}

Auteur: Idse Hoving (Wageningen Livestock Research)

Water is een zeer bepalende factor voor de productie van ruwvoer. Bij een voldoende nutriëntenvoorziening is in grote lijn de productie lineair evenredig met de beschikbaarheid van vocht (Doorenbos and Kassam, 1979). Dit betekent dat de verdampingsreductie die veroorzaakt wordt door droogte en vernatting de opbrengst van gras en ruwvoergewassen direct negatief beïnvloedt (zie 'Risico's droogte, vernatting en verzilting'). Voldoende zoet water is daarom van groot belang. Natuurlijke neerslag van water voorziet voor een groot deel in deze behoefte, echter door klimaatverandering verandert het neerslag patroon, waardoor in het groeiseizoen sneller tekorten optreden of oversschotten ontstaan. Naast neerslag is in de kustgebieden ook aanvoer van zoet water nodig om verzilting tegen te gaan.

De landbouw is zodoende in grote mate afhankelijk van een goede regulatie van de aan- en afvoer van water. De waterschappen en de landbouw zijn hiervoor verantwoordelijk. Voor de waterschappen is 'Waterbeheer $21^{\mathrm{e}}$ eeuw' vanuit het Ministerie van Infrastructuur en Waterstaat het sturende beleidsinstrument met als kernpunten veiligheid, wateroverlast en watertekort (www.helpdeskwater.nl).

Melkveehouders kunnen daarnaast door middel van sloten, greppels, stuwtjes en drainage in detail waterbeheer op bedrijfsniveau uitvoeren. Ook met de gewaskeuze en vruchtwisseling kan op droogte 
en vernatting geanticipeerd worden. Het is echter nog lastig te kwantificeren wat het effect is op de technische en economische bedrijfsresultaten. Er moeten nog wegen gevonden worden om waterbeheer met meer maatwerk uit te voeren, zodat zowel aan de doelen van de waterbeheerder als de wensen van de landbouw tegemoet gekomen wordt.

De gevolgen van klimaatverandering voor de melkveehouderij als het gaat om verdroging, vernatting, verzilting en waterberging zijn nauwelijks in beeld gebracht en gekwantificeerd. Zoals eerder aangegeven is de voorspelling dat de melkveehouderij vaker te maken krijgt met extremen als het gaat om droogte en wateroverlast, wat kan leiden tot verlies van ruwvoerproductie en grotere beperkingen voor het grondgebruik. Met het modelinstrumentarium Waterwijzer Landbouw (Werkgroep Waterwijzer Landbouw; zie kader) kunnen straks effecten van klimaatverandering berekend worden op perceelniveau en bedrijfsniveau. Belangrijk is hierbij is dat ook de veranderingen in wateraanvoer en waterafvoer goed ingeschat worden. Daartoe zullen ook op gebiedsniveau goede voorspellingen gedaan moeten worden.

\section{Risico's droogte, vernatting en verzilting}

Gewasopbrengsten zijn in belangrijke mate afhankelijk van de vochttoestand in de wortelzone en het zoutgehalte van het bodemvocht. Door droogte, vernatting en te hoge zoutgehaltes ${ }^{11}$ wordt de groei van gewassen gereduceerd. De grondwaterstand heeft een grote invloed op het vochtgehalte in de wortelzone. Peilbeheer, het al of niet vasthouden van water in vrij afwaterende gebieden en grondwaterwinning hebben een grote invloed op de grondwaterstand. Daarbij kunnen grondgebruikers ook zelf door maatregelen de vochttoestand in de wortelzone beïnvloeden zoals het aanleggen van drainage of het toepassen van beregening. Door klimaatverandering verandert het neerslagpatroon en de temperatuur. Ook dit heeft invloed op het vochtgehalte in de wortelzone.

De Waterwijzer Landbouw (zie kader) brengt de effecten van natheid, droogte en verzilting op landbouwgewassen in beeld. In de ontwikkeling van de Waterwijzer Landbouw wordt onderscheid gemaakt in directe en indirecte schade voor droogte, vernatting en verzilting. Het verlies aan gewasproductie treedt in de eerste plaats op door suboptimale bodemvochtcondities, de directe schade. Als de bodemvochtcondities niet optimaal zijn door een overmaat aan vocht, vochttekort of een te hoog zoutgehalte vermindert de gewasverdamping omdat de wortels onvoldoende water kunnen opnemen. Onder te natte omstandigheden treedt zuurstofstress op waardoor de wateropname door wortels vermindert.

\section{Waterwijzer Landbouw}

In 2013 is gestart met het ontwikkelen van het instrument Waterwijzer Landbouw dat de effecten van veranderingen of ingrepen in het watersysteem op landbouwgewassen in beeld brengt. Het gaat om de effecten van natheid, droogte en verzilting (http://waterwijzer.stowa.nl). Waterwijzer Landbouw moet de bestaande methodes (HELP-tabellen, de TCGBtabellen en AGRICOM) om effecten van ingrepen in de waterhuishouding op landbouwopbrengsten te bepalen vervangen (Bartholomeus et al., 2013). Herziening van deze methodes is gewenst omdat ze gebaseerd zijn op verouderde meteorologische gegevens en niet klimaatrobuust zijn. Daarbij geven ze alleen veeljarige gemiddeldes en wordt zoutschade niet meegenomen.

Anticiperen op klimaatverandering en het voorkomen van zoutschade gaat naar verwachting een steeds belangrijkere rol spelen in het waterbeheer. Het doel van Waterwijzer Landbouw is dat het een uniform, breed gedragen en praktisch instrument wordt voor het bepalen van klimaatbestendige relaties tussen waterhuishoudkundige condities en gewasopbrengsten. De methode moet zorgen voor een betrouwbare doelrealisatie voor de landbouw in de zogenoemde Waternoodsystematiek (met deze systematiek wordt op basis van de berekende grondwaterstanden, het bodemtype, het gewastype en de HELP-tabellen de nat- en droogteschade berekend), een realistische vaststelling van het gewenste grond- en oppervlaktewaterregime voor zowel het huidige klimaat als het klimaat van de (nabije) toekomst, alsmede voor betrouwbare effectvoorspellingen.

De Waterwijzer Landbouw bestaat uit een samenhangend modelinstrumentarium dat gebaseerd is op het hydrologische model SWAP en het gewasgroeimodel WOFOST en de resultaten van scenarioberekeningen die met deze modelkoppeling worden uitgevoerd. Het project is in vier fasen uitgevoerd en het instrument moet in 2018 gereed zijn voor gebruik. Het modelinstrumentarium wordt beschreven door de Werkgroep Waterwijzer Landbouw (in ontwikkeling).

\footnotetext{
${ }^{11}$ Op grasland treedt zoutschade niet of nauwelijks op.
} 
Indirecte schade is de vervolgschade die ontstaat door te natte, te droge of te zoute omstandigheden, bijvoorbeeld onvoldoende draagkracht van de graszode voor berijding en beweiding, vertrappingsverliezen, berijdingsverliezen, structuurbederf van de bodem, vertraagde gewasgroei door te koude grond in het voorjaar, verminderde stikstofmineralisatie en een toename van landbouwkundig matig of slecht gewaardeerde grassoorten. Indirecte schade wordt voornamelijk door vernatting veroorzaakt.

\subsubsection{Schade door wateroverlast}

Ten tijde van extreme regenval wordt het oppervlaktewatersysteem overbelast en lopen polders of laag gelegen gedeelten in beekdalen onder water of worden waterbergingsgebieden aangesproken om overstromingen elders te voorkomen. Het is de verwachting dat door klimaatverandering dit soort situaties vaker voorkomen, ook in het groeiseizoen, waardoor melkveehouders in deze gebieden schade oplopen. De tijd dat het land onder water staat (inundatie) is veelal beperkt tot minder dan een week. Na afvoer van water en het droogvallen van het maaiveld blijft de bovengrond vaak nog wel lange tijd nat, zeker bij ingesloten laagtes. Schade ontstaat door het verlies aan groeidagen, het ontstaan van spoelgaten, het achterblijven van zwerfvuil en het repareren van afrasteringen. Het herstellen van de schade en het opruimen van zwerfvuil kost veel arbeid. Het gras dat na inundatie niet door vee wordt gevreten moet worden gemaaid en afgevoerd. Dit brengt naast het productieverlies extra kosten met zich mee.

Er wordt onderscheid gemaakt in natschade (vorige paragraaf) en wateroverlast omdat de oorzaak van de schade anders is. De schade door wateroverlast is niet gerelateerd aan de grondwaterstand zoals dat bij natschade wel het geval is. Voor het vaststellen van inundatieschade zijn zodoende de methoden voor het bepalen van natschade (vorige paragraaf) niet bruikbaar. Wageningen Livestock Research heeft zodoende een apart rekenprogramma ontwikkeld (SchadeWijzer Inundatie) om de schade door inundatie op zandgrond te kunnen berekenen. Meer informatie is te vinden op http://www.wur.nl/nl/show/SchadeWijzer-Inundatie-1.htm.

\subsection{Adaptatiemaatregelen}

Auteur: Marion de Vries (Wageningen Livestock Research)

\section{Adaptatiebeleid}

De koers voor klimaatadaptatie in Nederland is uitgezet in de Nationale Klimaatadaptatie Strategie (NAS, 2016), welke een opmaat is naar het Uitvoeringsprogramma Klimaatadaptatie (NAS, 2018). Dit programma bouwt voort op reeds bestaande initiatieven, zoals het Deltaprogramma. Landbouw is één van de 9 sectoren in de NAS. Frequentere oogstschade en beschadiging van productiemiddelen door extreem weer zijn bestempeld tot één van de zes meest urgente effecten van klimaatverandering in de NAS. Extra bodemdaling en verzilting worden op termijn urgent (NAS, 2016).

Daarnaast bereidt Nederland zich voor op water-gerelateerde risico's van klimaatverandering in het Deltaprogramma, waarin effecten en adaptatiemaatregelen zijn doorgerekend (ter Maat et al., 2014). Hieruit blijkt dat veranderingen in de zoetwatervoorziening relatief beperkt zijn in het scenario voor matige klimaatverandering (G; Figuur 5), maar wateraanvoer sterk afneemt en watervraag sterk toeneemt in het scenario voor snelle klimaatverandering $(\mathrm{W}+)$. 


\section{Wat is klimaatadaptatie?}

Klimaatadaptatie is het aanpassen aan klimaatverandering, om kwetsbaarheid voor klimaatverandering te verminderen, negatieve effecten te verkleinen, en kansen te benutten (NAS, 2016).

Bij klimaatadaptatie kan onderscheid worden gemaakt in risico, kwetsbaarheid, en weerbaarheid (Gitz and Meybeck, 2012; IPCC, 2012):

1. Het risico is de potentie van factoren/stressoren om een (negatieve) verandering teweeg te brengen in een systeem (in dit geval het melkveebedrijf).

2. De kwetsbaarheid is de aanleg van het systeem om nadelig te worden beïnvloed door de factor. De kwetsbaarheid wordt bepaald door de blootstelling aan de factor (bijv. ziekte) en de gevoeligheid van het systeem (bijv. immuunstatus). De belangrijkste vraag is: kwetsbaarheid van "wat" voor "wat"? (Carpenter et al., 2002) Daarom is het belangrijk het (sub-) systeem te definiëren dat kwetsbaar is (bijv. grasland), de variabele die wordt beïnvloed (bijv. droge stof opbrengst), en het risico (bijv. kans op droogte of natschade).

3. De weerbaarheid (in het Engels: 'resilience') is het vermogen van een systeem om een risico te voorkomen, te verminderen, of te absorberen, of te herstellen van de gevolgen van een impact. Een systeem is weerbaar wanneer het minder kwetsbaar is voor een factor/stressor, en kan herstellen van een impact. Dit hangt samen met het aanpassingsvermogen van een systeem: herstellen van een impact, en het aanpassen aan veranderde omstandigheden (plasticiteit).

De weerbaarheid van systemen kan worden verbeterd door (Gitz and Meybeck, 2012):

1. Blootstelling te verminderen.

2. Gevoeligheid van systemen voor factoren/stressoren te verminderen.

3. Verbeteren van het aanpassingsvermogen, zowel om te herstellen van impacts van huidige risico's, alsook het vermogen/flexibiliteit om aan te passen aan veranderde omstandigheden met nieuwe risico's.

De uitgangspunten in deze benadering zijn vergelijkbaar met het beheersmodel en adaptatiemodel (zie Hoofdstuk Diergezondheid en Welzijn; bijv. Napel et al., 2006).

\section{Sector}

Sinds jaar en dag passen Nederlandse boeren zich aan veranderingen in het klimaat aan. Met haar huidige kennis en stand van technologie lijkt de Nederlandse landbouw goed bestand te zijn tegen veranderingen in het klimaat (Schaap et al., 2014). In sommige gevallen kan klimaatverandering naast de andere drukfactoren van bijvoorbeeld markt, beleid, en conflicterende belangen echter een extra negatieve impuls geven. Aan de andere kant liggen er kansen waarmee de sector haar concurrentievoordeel kan versterken, en is het van belang hier tijdig op in te spelen.

Adaptatiemaatregelen voor de melkveehouderij moeten zich richten op het verminderen van de kwetsbaarheid van systemen, door het verminderen van de blootstelling (bijv. uitroeien van een dierziekte, early-warning systemen) en gevoeligheid voor klimaatfactoren (bijv. droogte resistente gewassen, goede bodemkwaliteit waardoor planten minder stressgevoelig zijn). Daarnaast is het voor het verhogen van de weerbaarheid van systemen van belang goed te kunnen herstellen van impacts (bijv. door verzekeringen, ruwvoerbuffers), en zich te kunnen aanpassen wanneer nieuwe, onbekende risico's zich voordoen (bijv. flexibiliteit in de bedrijfsvoering). Een voorbeeld van het anticiperen op nieuwe, onbekende risico's is de beschikbaarheid van diverse genetische bronnen, zodat alternatieven voorhanden zijn wanneer omstandigheden veranderen op een manier waarin de huidige soort of ras niet meer volstaat.

Veel adaptatiemaatregelen liggen op reeds bekend terrein van praktijk en onderzoek, zoals verbetering van bodemkwaliteit, waterbeheer, veredeling, en preventie en bestrijding van ziekten en plagen. Daarnaast worden doorlopend nieuwe technieken ontwikkeld, zoals sensor technologie of robotisering. In de hierop volgende hoofdstukken is uitgewerkt wat mogelijke adaptatiemaatregelen zijn voor de deelonderwerpen gras en gewas, gewasbescherming, diergezondheid en welzijn, en waterbeheer. Hierbij wordt met name ingegaan op technische mogelijkheden, en in mindere mate op kosten en baten of economische risico's voor de sector, omdat dit buiten de afbakening van deze studie lag. 
Naast de maatregelen genoemd in de volgende hoofdstukken zijn er veel andere maatregelen die kunnen bijdragen aan klimaatadaptatie. Zo is het voor ondernemers in de sector is het van belang de (regio-/bedrijfsspecifieke) risico's en kansen van klimaatverandering te kennen en daar rekening mee te gaan houden (risicomanagement). Voor individuele bedrijven is het ontwikkelen van een effectieve strategie maatwerk. Technologie kan hier een belangrijke rol in spelen. Met behulp van technologie kan snel informatie worden verzameld (zoals voederwaarde gras), en op basis van beslissingsondersteunende systemen kan worden bijgestuurd indien nodig. Dit kan tevens bijdragen aan een efficiëntere bedrijfsvoering waarin verliezen worden beperkt en milieueffecten verminderd (precisie-landbouw). Op ketenniveau is het van belang kwetsbaarheden voor klimaatverandering in de totale aanvoerketen in kaart te brengen, en op basis daarvan de risico's in te schatten m.b.t. eventuele schaarste en prijsstijgingen. Hetzelfde geldt voor de afzetmarkt van producten (PBL, 2015b). Andere voorbeelden van interventies zijn innovatieve ontwerpen voor klimaatbestendige veehouderijsystemen, en verzekeringen voor effecten van weersextremen.

\subsubsection{Gras en gewas}

Auteur: Jantine van Middelkoop (Wageningen Livestock Research)

Van der Pol et al. (2012) noemen een aantal adaptatiemaatregelen die toepasbaar zijn voor Nederland:

- $\quad$ Het melkveehouderijsysteem wordt meer gebaseerd op geconserveerd voer voor dieren op stal en voerbudgettering voor droge seizoenen;

- Meer gebruik van mais;

- Meer gebruik van vlinderbloemigen in plaats van met stikstof bemest gras;

- Mestopslagcapaciteit vergroten en toedieningsmethoden verbeteren;

- Meer irrigatie/beregening nodig, indien beschikbaar: irrigatie/beregening biedt mogelijkheden om opbrengst te behouden of te verhogen onder droge omstandigheden;

- Gebruik van alternatieve ruwvoersoorten en mengsels die aangepast zijn aan droogte;

- De botanische samenstelling van het grasland zou soorten moeten gaan bevatten die om kunnen gaan met veranderende condities. De vraag is welke soorten vooral geschikt zouden zijn onder welke omstandigheden met behoud van de hoge (melk)productie;

- Verandering in graslandmanagement. Op dit moment zijn een aantal veranderingen te voorzien: aangepast moment van maaien (vroeger stadium), lengte van graasseizoen (mogelijk langer), bemesting aangepast aan de veranderende groeisnelheid en kwaliteit van het gras.

- $\quad$ Aanpassing van bijvoeding. Kwaliteit en kwantiteit van ruwvoeders (grasland) zullen sterk beïnvloed worden door de interactie van water beschikbaarheid en bodemkarakteristieken, zoals structuur, textuur, grondwatertrap en organische stof huishouding. Aanpassing van bijvoeding kan veranderende kwaliteit van ruwvoer opvangen.

Enkele opmerkingen bij bovenstaande adaptatiemaatregelen:

- $\quad$ Bij het gebruik van vlinderbloemigen is randvoorwaarde dat er voldoende fosfor en kali aanwezig is. Voor de komende jaren is in ieder geval fosfor voor Nederland geen probleem. Witte klaver heeft veel water nodig. Vlinderbloemigen met diepe wortelstelsels zouden uitkomst kunnen bieden (Luzerne (medicago sativa), rolklaver (lotus corniculatus)). Een andere diep wortelende plant is cichorei. Door toepassing van meerdere soorten zou de water efficiëntie van grasland kunnen verbeteren. 
- De opbouw of het behoud van organische stof wordt van belang geacht, vooral op akkerbouwmatig geteelde gewassen, voor verbetering van o.a. structuur en waterbergend vermogen van de bodem en opslag van koolstof in de bodem (mitigatie). Een mogelijkheid om organische stof te verhogen is akkerbouw in vruchtwisseling met grasland. Een zorgvuldige afweging van het inleveren van permanent grasland ten behoeve van kortere teelten is dan echter wel nodig: de opgebouwde organische stof onder permanent grasland verdwijnt snel wanneer het in rotatie met akkerbouwmatig geteelde gewassen komt.

- $\quad$ Randvoorwaarden zijn het vigerende mestbeleid. Naar verwachting zullen doelen in de Nitraatrichtlijn en Kaderrichtlijn Water blijven bestaan. Adaptatiemaatregelen kunnen door het mestbeleid in de hand gewerkt worden (bv stimulering zorgvuldig omgaan met mest) maar kunnen mogelijk andere maatregelen juist beperken. Een voorbeeld daarvan is de bemesting aanpassen aan de hogere behoefte van gewas bij meer groei. Door de hogere opname van andere nutriënten dan $\mathrm{N}$, zoals $\mathrm{P}$, maar het niet mogen verhogen van de mestgift kan de grasgroei beperkt worden door een gebrek aan deze andere nutriënten (Paas et al. 2016). De N/P-ratio in mest kan echter verschuiven door aangepaste rantsoenen waardoor gebrek aan andere nutriënten anders uitpakt dan verwacht. Door mestverwerking zou de N/P-ratio in mest eventueel gestuurd kunnen worden naar een gewenste samenstelling.

\section{Interacties met andere duurzaamheidsthema's}

- Meer mais telen kan gepaard gaan met hogere lachgasemissies en hogere nitraatuitspoeling. Wanneer oud grasland wordt gescheurd en omgezet naar mais komt een grote hoeveelheid eerder vastgelegde koolstof vrij als broeikasgas. Meer mais voeren gaat echter weer gepaard met lagere methaanemissies op dierniveau.

- $\quad$ Een stijging van gewasopbrengsten zal leiden tot extra nutriëntenopname en mogelijk met verlaging van uitspoeling of accumulatie van nutriënten. Belangrijk daarin is echter in welke verhouding nutriënten vooral via organische mestsoorten zullen worden toegepast en in hoeverre de verhouding kan worden aangepast door mestverwerking.

- Verschuiving van rantsoenen voor melkvee kan tijdens de stalperiode ammoniakvervluchtiging en tijdens beweiding nutriënten-emissie via de bodem veranderen. Over het algemeen zal een hoger aandeel stikstof in de voeding beide verhogen.

\subsubsection{Gewasbescherming}

Auteur: Rommie van der Weide (Wageningen Plant Research)

\section{Anticiperende maatregelen per gewas}

Anticiperende maatregelen voor de korte termijn zijn het monitoren op voorkomen van nieuwe gewasbelagers, het toenemen van de problematiek en het ingrijpen hierop. Hierbij kunnen we leren van de ervaringen die nu al opgedaan worden in de vergelijkbare gebieden. In Bijlage 2 is per ruwvoeder gewas opgenomen welke ziekten, plagen en onkruiden op ons afkomen en wat de consequenties zijn t.a.v. de beheersing in vergelijkbare gebieden. Het is hierbij belangrijk om de beschikking te hebben over een passend gewasbeschermingspakket, cq preventieve cultuurmaatregelen, op tijd de keuze te maken voor een aangepast cultivar, kennis te hebben over de schadelijkheid en de mogelijkheden voor correctie.

Bij nieuwe gewassen en soms ook bij nieuwe plagen onder Nederlandse omstandigheden, zal de teelt en de gewasbescherming verder doorontwikkeld moeten worden inclusief de beschikbaarheid van aangepaste rassen, schadedrempels, cultuur en fysische beheersingsmogelijkheden en toegelaten gewasbeschermingsmiddelen. 
Anticiperende maatregelen in het bouwplan

Om de risico's van het mislukken van teelten te verkleinen en de biodiversiteit en daarmee ook de weerbaarheid te verhogen is het wenselijk om meer diversiteit in tijd en ruimte aan te brengen. Het gaat hierbij om gebruik van vruchtwisselingen met korte(re) teelten, dubbelteelten, mengteelten, agroforestry en nieuwe teelten.

Een andere belangrijke maatregel is het verbeteren van de bodemstructuur en de bodemkwaliteit. Door niet te rijden met zware apparatuur op te vochtige grond en door de grondbewerking te verminderen en het gebruik van niet kerende grondbewerking kan de infiltratie van water en het vocht-naleverend vermogen van de bodem verhoogd worden. Verder kan op deze wijze de afbraak van organische stof in de grond verminderd worden. Verhoging van organische stof in de bodem is ook mogelijk door bemesting van natuurlijke oorsprong (op maat gemaakt met organische stof en ziektevrij in combinatie met vergisting, gebruik restproducten en raffinage) en de keuze van de teelten (jaarrond wortelgroei, groenbemesters etc.). Meer organisch stof verhoogt de weerbaarheid van de bodem. Niet kerende grondbewerking vraagt een aangepaste gewasbescherming.

\section{Aanbevelingen voor de praktijk}

Klimaatverandering heeft niet alleen direct effect op de ziekten en plagen, maar ook indirect door de aanpassing van gewaskeuze, rotaties en cultuurmaatregelen (West, 2012). Voor een adequate beheersing van ziekten, plagen en onkruiden bij een veranderend klimaat zijn de volgende maatregelen belangrijk (o.a. in Meissle et al., 2010; West et al., 2012; Lamichhane et al., 2015; Newbery et al., 2016).

Korte termijn:

- Monitoring van de ontwikkeling en verspreiding van gewasbelagers en eventuele maatregelen om verspreiding tegen te gaan;

- De optimale keuze van de juiste cultivars voor de teelt en de ontwikkeling van cultivars met geschikte resistenties voor de opkomende problemen;

- De beschikbaarheid van gewasbeschermingsmiddelen (chemisch, fysisch of biologisch; zoals Trichogamma tegen de maïsstengelboorder; Razinger et al., 2016), ook tegen nieuwe belagers of voor gebruik in nieuwe gewassen.

Langere termijn:

- Het ontwikkelen van optimale teelt en gewasbescherming voor nieuwe teelten, zoals b.v. aquatische teelten (micro algen, waterplanten);

- Het verbeteren van de bodemkwaliteit;

- Ontwerpen en toepassen van optimale vruchtwisseling, teeltvoorschriften en cultuurmaatregelen;

- Het vergroten van de biodiversiteit in de teelt (in tijd -vruchtopvolging en ruimte - mengteelten) en in het landschap eventueel zelf in combinatie met agroforestry - bomen op de akker (Del Prado et al., 2015; Liebman and Schulte, 2015; FAO, 2016)

\section{Interacties met andere duurzaamheidsthema's}

- Maatregelen om de bodem te verbeteren hebben niet alleen een gunstige invloed op gewasbescherming, maar bij een betere waterinfiltratie zijn er ook minder problemen met afspoeling van gewasbeschermingsmiddelen en nutriënten naar het oppervlaktewater.

- Het voorkomen van schimmels die mycotoxinen in het ruwvoer veroorzaken is van belang voor diergezondheid, evenals eventuele giftige kruiden en antibiotica resistente bacteriën die zich in de bodem in interactie met de mest ontwikkelen maar mogelijk ook in de planten/ruwvoer terecht kunnen komen. 
- Wat betreft mitigatie helpt een adequate gewasbescherming broeikasgasemissies te verminderen (West, 2012; Lamichhane, 2015). Del Prado (2015) schetst een beeld van mogelijke teeltaanpassingen in de melkveehouderij gericht op adaptatie en mitigatie. Een deel van deze gewenste aanpassingen hebben een duidelijke relatie met de gewasbescherming omdat ze de kwaliteit en daarmee ook de weerstand van de bodem beïnvloeden en/of omdat er een aangepaste gewasbescherming nodig zal zijn (www.beterbodembeheer.nl; Melander et al., 2013; Scopel et al., 2013; Deru et al., 2015; Huiting et al., 2016).

- Het aanpassen van de gewaskeuze of teeltduur om de diversiteit en daarmee de weerbaarheid te verhogen verandert tevens de interactie met waterbeheer. Ook kunnen nieuwe biobased teelten en geraffineerde reststromen een effect hebben op diergezondheid, en op methaanvorming in de pens. Agroforestry kan voor de nodige schaduw bij beweiding zorgen.

\subsubsection{Diergezondheid en dierenwelzijn}

Auteur: Jan ten Napel (Wageningen Livestock Research)

De Nederlandse melkveehouderij kan anticiperen op de mogelijke veranderingen langs twee oplossingsrichtingen, het beheersmodel en het adaptatiemodel (zie Tabel 4; Napel et al., 2006).

\section{Beheersmodel}

De eerste oplossingsrichting is vrijwaren, monitoren en ingrijpen. Een melkveebedrijf of de melkveehouderijsector probeert met preventiemaatregelen vrij te worden of vrij te blijven van een ziekteverwekker, monitort dit regelmatig en grijpt in als er onverhoopt toch besmetting is opgetreden of dreigt op te treden. Op dit moment monitort de GD routinematig de gezondheidssituatie in de rundveehouderij met de huidige situatie op Nederlandse bedrijven (BVD, IBR, leverbot) en de situatie op Europese bedrijven voor mogelijke bedreigingen (andere serotypes van het Blauwtongvirus).

Op wereldschaal hebben de FAO, de WHO en de OIE de handen in elkaar geslagen met GLEWS+, een wereldwijd systeem dat "informatie beschikbaar maakt voor preventie- en beheersmaatregelen, door snelle detectie en risicobeoordeling van bedreigingen van gezondheid en andere relevante gebeurtenissen op het raakvlak van mens-dier-ecosysteem". GLEWS+ richt zich op de gezondheid van mensen en dieren. Op sectorniveau en internationaal niveau bestaat er dus een adequaat monitoringssysteem voor bedreigingen die mogelijk de hele sector raken. Een snelle verspreiding van een onbekende ziekte of een ziekte met grote consequenties zal nationaal of internationaal worden bestreden. Monitoren van de diergezondheid op bedrijfsniveau kan via de dierenarts of via de GD voor specifieke dierziekten.

De tweede oplossingsrichting is op voorhand de impact beperken. Deze oplossingsrichting is vooral relevant als de kans op besmetting groot is, of als de impact veel mogelijke oorzaken heeft. Een voor de hand liggend voorbeeld is vaccinatie tegen virale ziektes die periodiek de kop op steken of die wel aanwezig zijn op bedrijven in de buurt. Een ander voorbeeld is voorkomen van diverse vormen van kalverdiarree door goed biestmanagement, melk van de juiste temperatuur en samenstelling aan te bieden en kalveren op schoon strooisel te huisvesten. Het zoveel mogelijk voorkomen van tijdelijke vatbaarheid door het vermijden van stress met onderdrukking van het immuunsysteem als gevolg past ook binnen deze oplossingsrichting.

De melkveehouderij heeft zich de laatste 10 jaar sterk ontwikkeld richting efficiëntieverbetering door optimalisatie van melkproductie. De managementstijl die hierbij past is het beheersen van de processen tot in steeds kleinere details. De eerste oplossingsrichting sluit hier het best op aan. Heel 
ver doorgevoerd leidt deze strategie echter tot een steeds hogere kostprijs en risico's met een steeds kleinere kans, maar een steeds grotere impact (Csete and Doyle, 2002).

\section{Adaptatiemodel}

De tweede oplossingsrichting heeft ruimte nodig om processen mee te laten bewegen met de dynamiek van de omgeving. Bijvoorbeeld een vector die een ziekteverwekker kan overbrengen gedijt beter door het veranderende klimaat. De ongewenste impact hiervan bestaat uit klinische symptomen en verspreiding van ziektekiemen door geïnfecteerde dieren. De impact van klimaatverandering op de vector kan verminderd worden door bijvoorbeeld de biotoop van de vector te beperken of ruimte te geven aan concurrentie en natuurlijke vijanden in de biotoop. De impact van toegenomen aantallen vectoren op de blootstelling van vee kan beperkt worden door beweiding aan te passen aan het gedrag van de vector of door insectenwerend gaas te gebruiken in ventilatieopeningen. De impact van toegenomen blootstelling op het aantal infecties kan mogelijk beperkt worden door het beperken van besmetting van de vector door latente dragers te identificeren en dieren met klinische symptomen te behandelen. De impact van infectie op het optreden van klinische symptomen kan beperkt worden met vermijden van tijdelijke vatbaarheid en opbouw van weerstand tegen de ziektekiem. Op verschillende niveaus wordt zo de impact van klimaatverandering op ziekte geabsorbeerd. Hiervoor is er ruimte nodig om percelen anders in te richten, het beweidingsplan aan de omstandigheden aan te passen, latente dragers te traceren en producerende dieren zich aan te laten passen.

Beide oplossingsrichtingen vullen elkaar dus aan (ten Napel et al., 2011). De balans tussen beide oplossingsrichtingen moet voor elk ziektecomplex afzonderlijk bepaald worden. De eerste oplossingsrichting heeft de voorkeur als het moet (zoönose, ziekte met meldingsplicht) of als het efficiënt is (bedrijfshygiëne). De tweede oplossingsrichting heeft de voorkeur als het kan (zo eenvoudig mogelijk bouwen, stalbodems die gunstig zijn tegen klauwproblemen).

Tabel 4 Oplossingsrichtingen en voorbeelden van adaptatiemaatregelen op verschillende systeemniveaus.

\begin{tabular}{|c|c|c|c|}
\hline & Internationaal & $\begin{array}{l}\text { NL melkveehouderij- } \\
\text { sector }\end{array}$ & Melkveebedrijf \\
\hline \multicolumn{4}{|l|}{$\begin{array}{l}\text { Tegen bron gericht } \\
\text { (beheersmodel): }\end{array}$} \\
\hline Preventie & $\begin{array}{l}\text { Reguleren } \\
\text { internationale handel }\end{array}$ & $\begin{array}{l}\text { Vrije status, reguleren } \\
\text { internationale handel }\end{array}$ & $\begin{array}{l}\text { Bio-security, bedrijfshygiene, insektengaas, } \\
\text { repellents }\end{array}$ \\
\hline Ingrijpen & Eradicatieprogramma & $\begin{array}{l}\text { Ruiming, } \\
\text { gezondheidsprogramma }\end{array}$ & $\begin{array}{l}\text { antibiotica-behandeling, Gevolgen van } \\
\text { infrequente extremen (bijv. neerslagoverschot) } \\
\text { oplossen met management, niet door } \\
\text { systeemaanpassing. }\end{array}$ \\
\hline
\end{tabular}

Tegen impact van bron gericht

(adaptatiemodel):

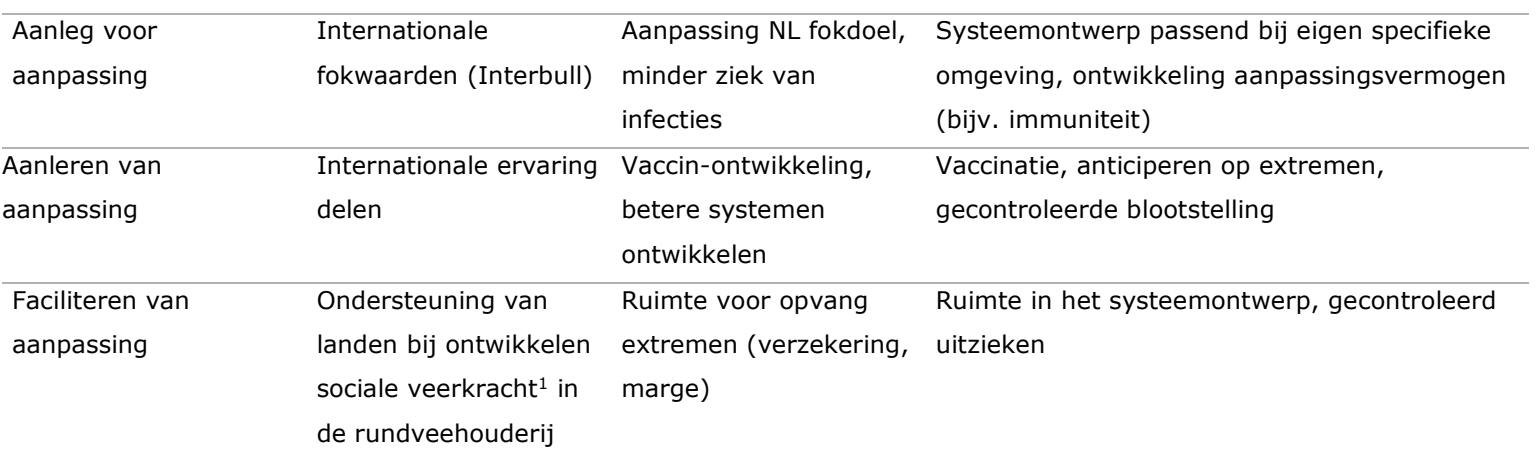

1 Met sociale veerkracht wordt bedoeld dat een sector in de lokale omstandigheden en samenleving ingebed moet zijn. Een sector die lokaal ingebed is kan de dynamiek en uitdagingen waaraan een sector bloot staat beter opvangen. 
Interacties met andere duurzaamheidsthema's

Omdat de precieze impact van klimaatverandering op gezondheid en welzijn van melkvee ook sterk afhangt van andere factoren, is het alleen mogelijk om afwentelingen en synergiën globaal te beschrijven.

Afwentelingen:

- Wanneer grasland voor waterberging wordt gebruikt bij overmatige neerslag kunnen ingesloten laagtes met water op het land een aantrekkelijke biotoop zijn voor insecten en slakken die ziekten of parasieten overdragen, of zelf voor overlast zorgen.

- Bij een sterke toename van de ziektedruk via vectoren kan beweiding onder druk komen te staan en het percentage melkkoeien dat nooit buiten komt toenemen.

Synergiën:

- Vergroten van biodiversiteit in het grasland verkleint mogelijk de kans dat één of enkele soorten insecten zich ontwikkelen tot een plaag door concurrentie en natuurlijke vijanden.

\subsubsection{Waterbeheer}

Auteur: Idse Hoving (Wageningen Livestock Research)

\section{Beleid}

Om de veranderingen in het klimaat voldoende het hoofd te kunnen bieden moet in de eerste plaats Nederland landelijk de waterhuishouding op orde hebben. In de jaren negentig van de vorige eeuw hebben zich een aantal keren onveilige situaties voorgedaan door wateroverlast die ontstonden door intensieve en langdurige regenperioden. In december 1993 bereikte het water in de Maas een recordhoogte waardoor in Limburg op meerdere plaatsen de Maas buiten de oevers trad en meerdere plaatsen waaronder Gennep, Itteren en Borgharen onder water zette. In januari van 1995 vonden langs de Maas wederom veel overstromingen plaats en dreigde de Ooijpolder onder water te lopen doordat de dijk van de Waal het bijna begaf. In het najaar van 1998 vond in Zuidwest- en NoordoostNederland veel wateroverlast plaats. De financiële schade door de overstromingen liep in de honderden miljoenen guldens.

Naar aanleiding van deze gebeurtenissen heeft de Commissie Waterbeheer 21e eeuw (WB21) advies uit gebracht over de waterhuishoudkundige inrichting van Nederland met als kernpunten veiligheid, wateroverlast en watertekort. Daarbij is aandacht gevraagd voor een andere aanpak van het waterbeheer: meer ruimte voor water, meer betrokkenheid van burgers en overheid, een betere sturing en regie bij het waterbeleid (http://www.helpdeskwater.nl).

Om veiligheid te creëren en schade door wateroverlast of droogte te voorkomen of te beperken, heeft de Commissie voor een drietrapsstrategie gekozen (Basisrapport Waterbeheer 21e eeuw). Daarin zijn de elementen stroomgebied benadering, geen afwenteling en ruimte voor water te herkennen:

1. Overtollig water zoveel mogelijk bovenstrooms al vasthouden in de bodem en in het oppervlaktewater;

2. Zo nodig water tijdelijk bergen in retentiegebieden langs de waterlopen. Daarvoor moet ruimte worden gecreëerd;

3. Pas wanneer 1 en 2 te weinig opleveren, water afvoeren naar elders of, als dat niet kan, het water opvangen in gebieden die gecontroleerd onder water gezet kunnen worden bij afvoeren die hoger zijn dan de maatgevende afvoeren. 
De Commissie heeft deze strategie uitgewerkt in vier oplossingsrichtingen voor afwegingen die beleidsmakers zouden moeten hanteren:

- Primair problemen oplossen door ruimtelijke (her)inrichting en ander grondgebruik;

- Waar mogelijk anticiperen via flexibel peilbeheer;

- Voor zover nodig ruimte bestemmen en inrichten voor waterberging;

- Waar het niet anders kan technische maatregelen nemen voor waterafvoer.

Voor het afwegen van afzonderlijke maatregelen die onderdeel uitmaken van de verschillende oplossingsrichtingen heeft de Commissie de volgende criteria opgesteld:

- De mate waarin veiligheid wordt gegarandeerd;

- De mate waarin wateroverlast (door te veel maar ook door te weinig water) wordt voorkomen;

- De bijdrage aan ecologische duurzaamheid (veerkracht, natuurlijkheid en waterkwaliteit);

- De kansen en bedreigingen voor een economische bedrijfsvoering (voor de landbouw en dergelijke);

- De benodigde ruimte versus de beschikbare ruimte;

- De bijdrage aan de ruimtelijke kwaliteit in het algemeen;

- De maatschappelijke en bestuurlijke acceptatie;

- De kosten;

- De baten.

Als voorbeeld heeft Waterschap Rivierenland voor het gebied Groesbeek en Ooijpolder extra maatregelen voorbereid die het probleem van wateroverlast moeten voorkomen:

- technische maatregelen (bv. vervangen van te krappe duikers);

- $\quad$ aanleg natuurvriendelijke oevers;

- $\quad$ aanleg van extra watergangen (sloten, weteringen e.d.);

- verbreden van watergangen.

De maatregelen nemen extra ruimte in beslag, afgezien van de technische maatregelen. Op overheden, maatschappelijke organisaties en particulieren wordt een beroep gedaan om deze ruimte te bieden en om zo wateroverlast te voorkomen. Daarbij wordt via een regeling de aanleg van natuurvriendelijke oevers gestimuleerd om een alternatief te bieden voor aan- of verkoop van grond. Door gedifferentieerd op vele plaatsen extra ruimte te creëren voor water wordt de aanleg van grootschalige waterbergingsgebieden voorkomen.

\section{Melkveehouder}

In het project Landbouw op peil voor Oost-Nederland (2010-2015) is een reeks van maatregelen ingezet en gemonitord op 15 praktijkbedrijven in het kader van veranderende klimaatomstandigheden (Tabel 5). Landbouw op peil is geïnitieerd door de waterschappen uit het deelstroomgebied Rijn-Oost, provincies, LTO-Noord en het ministerie van Economische Zaken, Landbouw \& Innovatie (EL\&I) om meer inzicht te krijgen in perspectiefvolle maatregelen die de weerbaarheid van agrarische bedrijven vergroot (Staarink et al., 2014). Voor negen van de gemonitorde bedrijven zijn modelberekeningen uitgevoerd met het hydrologische model SWAP voor de weerjaren 2001-2011 en het KNMIklimaatscenario $2006(\mathrm{~W}+)$ om de effectiviteit en kosteneffectiviteit te bepalen. De meeste maatregelen zijn dusdanig effectief dat ze op de lange termijn worden terug verdiend. 
Tabel 5 Adaptatiemaatregelen voor het vergroten van weerbaarheid van melkveebedrijven onder klimaatverandering in het project Landbouw op Peil in Oost-Nederland (2010-2015).

\begin{tabular}{|c|c|}
\hline Maatregel & Toelichting \\
\hline Waterbeheer met 'boeren' stuwen & Vasthouden van water met stuwen die door boeren zelf bediend worden \\
\hline (Samengestelde) Peilgestuurde & Gedoseerd kunnen af- en aanvoeren van water \\
\hline \multicolumn{2}{|l|}{ Drainage } \\
\hline Ondiepe nauwere drainage & Vergroten waterafvoer, zonder extra verdroging te veroorzaken \\
\hline Beregening & Additionele aanvoer van grond- of oppervlaktewater voor het opheffen van droogte \\
\hline Extra wateraanvoer & Vergroten beschikbaarheid van water voor infiltratie in de bodem \\
\hline Waterbuffering & Vasthouden van water in perioden met een neerslagoverschot \\
\hline Inunderen en infiltreren & Onder water zetten van grond voor waterbuffering) \\
\hline (automatisch) stuwbeheer & Vasthouden van water met stuwen in grotere waterlopen \\
\hline 'Boeren'-berging & Berging van water op landbouwgrond \\
\hline Grondwatergestuurd peilbeheer & Peilbeheer waarbij de actuele grondwaterstand leidend is \\
\hline Alternatieve gewassen & Voedergewassen anders dan gras of snijmaïs \\
\hline $\begin{array}{l}\text { Aangepaste (beperkte) } \\
\text { grondbewerking }\end{array}$ & Grondbewerking waarbij minder organische stof afbreekt \\
\hline $\begin{array}{l}\text { Egaliseren of juist bol leggen van } \\
\text { percelen }\end{array}$ & Aanpassen ligging maaiveld om afvoer of vasthouden van water te beïnvloeden \\
\hline Opheffen storende lagen & $\begin{array}{l}\text { Verminderen bodemverdichting om infiltratie van water en worteldiepte te } \\
\text { bevorderen }\end{array}$ \\
\hline $\begin{array}{l}\text { Verbeteren bodemstructuur, -chemie } \\
\text { en biologie }\end{array}$ & Bevorderen infiltratie van water en worteldiepte \\
\hline Verhogen organische stofgehalte & Verbetert bodemstructuur en vergroot vochtbeschikbaarheid \\
\hline Vanggewassen en onderzaai & Helpt om in akkerbouwmatige teelten organisch stofgehalte op peil te houden \\
\hline
\end{tabular}

\section{Aanbevelingen voor de praktijk}

\section{Realisatie wateropgave}

In het project Landbouw op peil was een belangrijke bemerking dat het toepassen van maatregelen, zoals die in paragraaf 2.4 uiteengezet zijn, een lange termijn visie vraagt op het gebied van bodemen waterbeheer van zowel de agrarische ondernemer als van de waterbeheerder. Dit betekent dat er ruimte en beweging moet ontstaan om gezamenlijk te werken aan de realisatie van de wateropgave zoals die in WB21 verwoord is (Staarink et al., 2014). Het nemen van maatregelen vergt investeringen en de vraag die voor Waterschappen bij een (lokale) investeringsvraag tekens terugkwam is: wat is het causale verband tussen de maatregel en de wateropgave. Deze vraag bleek moeilijk te beantwoorden omdat de bestaande instrumenten onvoldoende antwoord gaven op deze vraag of omdat de kennis ontbrak.

\section{Dynamischer waterbeheer met meer verantwoordelijkheden voor landbouw}

Daar waar de fysieke afstand tussen agrarische ondernemer en het waterschap door fusies van waterschappen toeneemt, vraagt een dynamischer watersysteem maatwerk en is juist een verkleining van de afstand en een meer praktischere benadering vereist. Waterschappen zullen een werkvorm moet vinden waarin dit te realiseren is. Door de toenemende schaalgrootte in de landbouw worden bedrijven steeds groter en minder talrijk waardoor het misschien mogelijk wordt om landbouw meer verantwoordelijkheden te geven voor de uitvoering van waterbeheer als het gaat om onderhoud en peilbeheer van de haarvaten van het watersysteem wanneer hier goede afspraken over gemaakt worden.

'Sturen met water' is een project dat in opdracht van de provincies Zuid-Holland en Utrecht wordt uitgevoerd (2015-2017) door Wageningen Research. In dit project is een aanpak beproefd waarbij 
voor de polder Teckop/Kockengen waterschappen, landbouw maar ook andere stakeholders het waterbeheer gezamenlijk met hebben vormgegeven zodanig dat de doelen van betrokken partijen zoveel mogelijk werden verenigd. De aanpak in de vorm van ontwerpateliers bleek voor deze polder een succes, vooral omdat de deelnemers de urgentie van ieders probleem ervoeren en de bereidheid er was om tot een gezamenlijke oplossing te komen. De multi-actor samenwerking in 'Sturen op water' vormt daarmee een goed voorbeeld van een effectieve aanpak om waterbeheer vorm te geven.

Interacties met andere duurzaamheidsthema's

Naast de nutriënten voorziening is water de belangrijkste productiefactor voor gewasgroei. Een suboptimale vochtvoorziening heeft direct invloed op de gewasproductie. Daarbij hebben te natte omstandigheden ook een indirect effect omdat de beweidingsmogelijkheden en de berijdbaarheid van de grond met machines wordt beperkt. Daarbij zorgen vertrappingsverliezen voor een lagere grasbenutting. De directe en indirecte effecten brengen hogere loonwerk en voerkosten met zich mee.

Het toepassen van zogenaamde onderwaterdrains in het veenweidegebied is niet alleen adaptatiemaatregel, maar tevens een belangrijke mitigatiemaatregel (zie Hoofdstuk 2). Onderwaterdrains is een vorm van drainage, waarbij de drainbuizen onder slootpeil zijn aangelegd, zodat deze zowel kunnen draineren als infiltreren om respectievelijk de bodem droger of natter te maken. In het veenweidegebied halveert maaivelddaling door veenafbraak door het toepassen van onderwaterdrains in combinatie met relatief hoge slootpeilen (Van den Akker et al., 2007; Hoving et al., 2008; van den Akker et al., 2010; Van den Akker et al., 2012; Akker and Hendriks, 2017). Door de verminderde veenafbraak reduceert het vrijkomen van kooldioxide en lachgas (zie schatting emissiereductie in het kader 'Vermindering van emissies uit veengronden' in Hoofdstuk 2). 


\section{$4 \quad$ Routekaart}

\subsection{Introductie}

In Hoofdstuk 2 en 3 van dit rapport zijn een groot aantal maatregelen beschreven voor het reduceren van broeikasgasemissies en het verbeteren van de klimaatbestendigheid van melkveebedrijven. Maatregelen kunnen niet allemaal direct worden ingezet, en dat is ook niet verstandig. Prioritering en fasering van de inpassing van maatregelen is van belang voor een strategische en integrale aanpak van de mitigatie- en adaptatieopgave. Hierbij moet rekening worden gehouden met effectiviteit, kosten en praktijkrijpheid, en afwentelingen naar andere duurzaamheidsthema's. Met name voor de emissiereductiedoelstellingen moeten op korte termijn grote slagen worden gemaakt. Door de inzet van maatregelen te faseren ontstaat er een route naar een klimaatslimme melkveehouderij.

In dit hoofdstuk wordt een routekaart gepresenteerd voor inpassing van mitigatie- en adaptatiemaatregelen op de korte (2030) en middellange (2050) termijn. De routekaart betreft een gefaseerde inzet van klimaatslimme maatregelen, waarbij rekening wordt gehouden met kosten, afwentelingen en praktijkrijpheid van maatregelen. We laten zien hoe een flexibele planning van maatregelen eruit kan zien, waardoor de sector tijdig kan anticiperen op onvoorziene omstandigheden of onvoldoende resultaat.

\subsection{Autonome ontwikkeling: wat gebeurt er als de sector niets doet?}

\section{Uitstoot van broeikasgassen}

De opgave voor reductie van broeikasgasemissies in de melkveehouderij vloeit voort uit nationale en Europese beleidsdoelstellingen (zie Hoofdstuk 2). Deze doelstellingen zijn gericht op het totale emissievolume, welke wordt beïnvloed door emissie intensiteit en melkproductievolume. In het verleden is een reductie van de emissie intensiteit met name behaald door efficiëntieverbeteringen (maatregelen in cluster 1 van Hoofstuk 2). Deze strategie komt vooral voort uit de mineralenvraagstukken gericht op een betere mineralenbenutting en niet op extensivering. De efficiëntie strategie is ook belangrijk om de kostprijs laag te houden. Ook in de discussie over implementatie in de praktijk ligt er veel nadruk op de maatregelen uit de categorieën efficiëntieverbeteringen en hernieuwbare energie, welke veelal kosteneffectief zijn of gestimuleerd worden door de zuivelsector. Voor wat betreft het totale emissievolume is te zien dat - ondanks een daling van het emissievolume in het melkquotum tijdperk - in recente jaren het totale emissievolume van de sector weer is toegenomen (Figuur 4 in Hoofdstuk 2). Dit is met name veroorzaakt door een stijging van het productievolume bij een vrijwel gelijkblijvende emissie intensiteit.

Wanneer deze trends worden doorgetrokken naar de toekomst is de verwachting dat inspanningen om broeikasgasemissies te verlagen zich met name zullen blijven richten op efficiëntieverbeteringen en hernieuwbare energie. De emissiereductie door efficiëntieverbeteringen zal met een gelijkblijvend melkvolume echter onvoldoende zijn om een forse emissiereductie in 2030 en 2050 te realiseren, vooral wanneer compensatie van emissies door hernieuwbare energieproductie niet mogelijk is. Op 
basis van de analyse van de sectorrapportage is de emissie per $\mathrm{kg}$ melk van de $5 \%$ beste bedrijven gemiddeld 0.98 kg CO2 equivalenten per kg melk (Doornewaard et al., 2017). Dat is 15\% lager dan de gemiddelde emissie intensiteit. Dat betekent dat bij een gelijkblijvend productievolume het emissievolume 15\% kan dalen wanneer de gehele sector er in slaagt om op het emissieniveau van de top $5 \%$ uit te komen. Wanneer het aantal dieren gelijk blijft en het productievolume verder stijgt door een doorzettende trend in melkproductiestijging per koe (ongeveer 1\% per jaar; CRV jaarstatistieken) zal een reductie van $15 \%$ emissie intensiteit slechts een beperkt effect op het totale emissievolume hebben. Wanneer niet tijdig wordt gestart met het nemen van maatregelen kan inkrimpen van de veestapel noodzakelijk zijn.

Het productievolume van de sector wordt momenteel beperkt door o.a. de invoering van fosfaatrechten. Dit zal het melkvolume en daarmee het totale emissievolume op korte termijn iets doen dalen. In het geval van fosfaatrechten kan de productie echter weer gaan stijgen wanneer de melkveehouderij zich richt op optimalisering van de melkproductie per kg fosfaatexcretie. De huidige gemiddelde melkproductie per $\mathrm{kg}$ fosfaatexcretie is ongeveer $150 \mathrm{~kg}$. In studiegroepen worden waarden aangetroffen tot meer dan $200 \mathrm{~kg}$ melk per $\mathrm{kg}$ fosfaatexcretie. Op de langere termijn zal de fosfaatexcretie dus niet een beperking vormen voor de groei van het productievolume van melk. Ook grondgebondenheid zal consequenties hebben voor het emissievolume, door enerzijds meer koolstofvastlegging in grasland, maar ook meer enterische methaan emissies uit de pens door een groter aandeel gras in het rantsoen ten koste van snijmais.

\section{Gevolgen van klimaatverandering voor de melkveehouderij}

Gezien de grote onzekerheden omtrent klimaatscenario's en andere economische en sociaalmaatschappelijke ontwikkelingen is het niet eenvoudig om te voorspellen wat er zal gebeuren als bedrijven niet actief maatregelen treffen om de klimaatbestendigheid te verhogen. Hoofdstuk 3 laat zien dat enerzijds de stijgingen in temperatuur en $\mathrm{CO}_{2}$ concentraties waarschijnlijk een positief effect op het bruto bedrijfsresultaat in 2050 zullen hebben, maar anderzijds dat klimaatextremen dit positieve effect kunnen afzwakken of teniet doen (Paas et al., 2016). Andere factoren (technologie-, beleid- en marktontwikkeling) hebben echter waarschijnlijk meer invloed op de ontwikkeling en prestaties van bedrijfssystemen dan klimaatverandering. Omtrent zowel klimaat- als economische en sociaalmaatschappelijke scenario's is echter veel onzeker, zowel wat betreft de grootte van impact als de frequentie. Ook de kansen op uitbraken of versnelde verspreiding van dierlijke of plantaardige ziekten en plagen zijn lastig te voorspellen. Daarnaast zijn effecten sterk locatie afhankelijk.

Duidelijk is dat een vorm van risicomanagement nodig is om om te gaan met de grote onzekerheden rond mogelijke effecten van klimaatverandering. Verwacht wordt dat in eerste instantie de sector zelf vooral goed zal inspelen op de kansen die klimaatverandering biedt (Schaap et al., 2014), zoals mogelijkheden om voerproductie te verbeteren door veranderingen in temperatuur en $\mathrm{CO}_{2}$ concentratie in de lucht. In de routekaart in dit rapport ligt daarom de nadruk op maatregelen die de sector weerbaarder moeten maken voor negatieve effecten van klimaatverandering, als een vorm van risicomanagement.

\subsection{Routekaart voor inpassing van klimaatslimme maatregelen}

Klimaatmitigatie en -adaptatie in de melkveehouderij hebben verschillende vertrekpunten: terwijl mitigatie al in de fase van pilotprojecten en implementatie is, staat klimaatadaptatie nog in de kinderschoenen en is kennis sterk gefragmenteerd in deelthema's. Daarnaast is bij adaptatie de keuze 
van maatregelen meer afhankelijk van de locatie (bijv. grondsoort) en het bedrijfstype (bijv. intensiteit), in combinatie met specifieke klimaatrisico's. Het verdient bij adaptatie daarom de voorkeur om de routekaart uit te werken voor een specifieke situatie en een specifiek klimaatrisico. Voor mitigatie en adaptatie zijn daarom twee losstaande routekaarten uitgewerkt. Bij adaptatie is gekozen voor case studie: hier is een routekaart uitgewerkt voor bedrijven op droogtegevoelige gronden in relatie tot het toenemende risico op langdurige droogte.

Voor beide routekaarten zijn eerst maatregelen geprioriteerd op basis van effectiviteit, kosten, praktijkrijpheid en afwentelingen naar andere duurzaamheidsthema's. De routekaart wordt uitgebeeld in een figuur waarin op basis van de prioritering een voorkeursroute van maatregelen is uitgestippeld in de tijd. In een tweede stap wordt toegelicht hoe een flexibele planning eruit ziet, waardoor alternatieve routes in beeld worden gebracht en het mogelijk is de voorkeursroute te verleggen wanneer omstandigheden daarom vragen.

\subsubsection{Flexibel plannen}

In de toekomst zal de sector te maken krijgen met externe factoren die nu nog onzeker zijn. Dat betreft niet alleen klimaatverandering, maar bijvoorbeeld ook toekomstig beleid, sociaalmaatschappelijke en economische ontwikkelingen, of nieuwe technologieën. Wanneer de sector een planning maakt op de aanname dat de toekomst voorspelbaar is, faalt het plan als de toekomst anders is dan was voorspeld. Dit geldt met name voor de implementatie van adaptatiemaatregelen, omdat scenario's voor klimaatverandering een hoge mate van onzekerheid vertonen, maar ook voor de implementatie van mitigatiemaatregelen: klimaatdoelstellingen staan weliswaar vast, maar externe factoren kunnen de keuze van maatregelen beïnvloeden (bijv. door aandacht voor andere thema's zoals grondgebondenheid of biodiversiteit, of veranderingen in beleid). Maar ook voor mitigatiemaatregelen kan implementatie in de praktijk worden beïnvloed door externe factoren die nu nog onzeker zijn, of onvoldoende resultaat geboekt met geplande maatregelen.

Om met dergelijke onzekerheden om te gaan is het van belang dat het traject naar een klimaatslimme melkveehouderij niet een statisch- maar een flexibel traject is, waarbij de route kan worden aangepast wanneer omstandigheden veranderen. Het verdient daarom de voorkeur om een flexibele planning te maken, in plaats van één optimaal traject (Haasnoot et al., 2011). In een flexibele planning wordt een route uitgezet voor de implementatie van maatregelen, maar worden tevens alternatieve routes in beeld gebracht waardoor het mogelijk is de route te verleggen wanneer omstandigheden daarom vragen. Met een dergelijke routekaart is het mogelijk ver vooruit te kijken en tijdig maatregelen te nemen die op dat moment nodig en betaalbaar zijn.

De identificatie en bewustwording van alternatieve routes zijn een vorm van risicomanagement. Voor zover mogelijk is het van belang deze risico's te kennen (bijv. toekomstig beleid, sociaalmaatschappelijke en economische ontwikkelingen, nieuwe technologieën, klimaatverandering), alternatieve routes te definiëren, en tijdig in te zien wanneer een koersverandering nodig is.

\subsubsection{Mitigatie}

Voor de routekaart in dit rapport zijn alleen mitigatiemaatregelen op bedrijfsniveau meegenomen. Maatregelen waarvoor een afwenteling van broeikasgasemissies naar andere delen van de keten verwacht werd zijn niet opgenomen. Maatregelen die bijdragen aan een reductie van $\mathrm{CO} 2$ emissies of opslag van koolstof in de bodem zijn wel opgenomen, i.v.m. de mogelijkheid om emissies uit te wisselen met ETS en LULUCF sectoren in ESR beleid (zie Hoofdstuk 2). 


\section{Fasering van maatregelen}

In deze studie zijn maatregelen gefaseerd door eerst maatregelen in de categorieën 'laag hangend fruit' en 'lage kosten' in te zetten, en later maatregelen die nu nog niet praktijkrijp zijn of nog te hoge kosten met zich meebrengen (Tabel 7). Uit kwantitatieve analyses moet blijken in hoeverre de maatregelenpakketten voldoende zijn voor het behalen van emissiereductiedoelstellingen van de sector voor 2030 (bijv. Vellinga et al., in voorbereiding). Onze verwachting is dat maatregelen uit de categorieën 'laag hangend fruit' en 'lage kosten' voldoende emissiereductie opleveren om beleidsdoelstellingen in 2030 te behalen. Omdat niet ingezet wordt op verhoging van de melkproductie en verlenging van de levensduur, is een brede toepassing van de maatregelen in deze pakketten echter wel een vereiste. Daarnaast hangt de inzet van maatregelen die betrekking hebben op energie en koolstofopslag in de bodem af van resultaten van onderhandelingen m.b.t. de bijdrage van de sector aan ETS en LULUCF (zie Hoofdstuk 2).

Tabel 7 laat zien dat op de korte termijn diverse maatregelen op het gebied van gewassen, vee, en mest kunnen worden ingezet, zonder substantiële afwentelingen naar andere duurzaamheidsthema's of hoge kosten. In eerste instantie moeten maatregelen met name gericht zijn op de reductie van methaan en lachgas zodat reductiedoelstellingen voor 2030 worden behaald. Daarnaast kan de sector op verschillende manieren de vastlegging van koolstof in landbouwgronden verhogen en een bijdrage leveren aan hernieuwbare energieproductie. Op de middellange termijn worden maatregelen ingezet die nu nog niet praktijkrijp of te kostbaar zijn. Daarmee zouden emissies uit mestopslagen en door fossiele energiegebruik kunnen worden geëlimineerd. Emissies op dierniveau en uit mest in de stal kunnen sterk worden teruggebracht, maar niet worden geëlimineerd. Op de middellange termijn zal het gebruik van energie voor maatregelen niet langer bijdragen aan hogere emissies, omdat alleen nog hernieuwbare energie wordt gebruikt. De sector kan een forse bijdrage leveren aan de productie van hernieuwbare energie, en tevens aan een (circulaire) bio-based economy door het verwaarden van mest. Om de lage emissie intensiteit te behouden moet de sector kansen door klimaatverandering benutten (bijv. hogere temperaturen en $\mathrm{CO} 2$ concentratie in de lucht), en zorgen dat nadelige effecten van weersextremen worden voorkomen. Op de lange termijn draagt de sector bij aan minimalisering van emissies in het gehele voedselsysteem.

Een hoger melkproductie per koe en een langere levensduur per koe (minder jongvee) zijn niet opgenomen omdat afwentelingen van broeikasgasemissies naar de vleessector worden verwacht (Vellinga en De Vries, 2018; als de consumptie van rundvlees daalt kunnen beide maatregelen wel zinvol zijn). Daarnaast is bij melkproductieverhoging voorzichtigheid geboden omdat een verdergaande conditionering de kwetsbaarheid mogelijk kan verhogen (zie ook discussie). Bij een hogere melkproductie per koe nemen emissies uit voer en mest per dier toe. Het totale emissievolume uit de sector neemt daarom alleen af wanneer het totale melkvolume gelijk blijft of slechts licht stijgt, en daartoe de omvang van de veestapel verkleind wordt. 
Tabel 7 Fasering van mitigatiemaatregelen op korte termijn en middellange termijn, op basis van kosten, afwentelingen en praktijkrijpheid.

\begin{tabular}{|c|c|c|}
\hline & Korte termijn & Middellange termijn \\
\hline Bodem & $\begin{array}{l}\text { Hoger OS gehalte door: } \\
\text { - Lagere frequentie van scheuren en herinzaai } \\
\text { van grasland } \\
\text { - Meer doorzaai i.p.v. herinzaai } \\
\text { - Verbeterde vruchtwisseling van grasland en } \\
\text { mais } \\
\text { - Meer gebruik van vanggewassen en } \\
\text { gewasresten } \\
\text { - Bijdrage aan hoger OS gehalte in akkerbouw } \\
\text { via dierlijke mest, vruchtwisseling met } \\
\text { grasland, en optimale benutting van } \\
\text { gewasresten als veevoer } \\
\text { - In veengebieden wordt peilverhoging i.c.m. } \\
\text { onderwaterdrainage toegepast }\end{array}$ & $\begin{array}{l}\text { - Optimaal OS gehalte in landbouwgronden } \\
\text { melkveehouderij } \\
\text { - Melkveehouderij draagt niet bij aan } \\
\text { bodemdaling in veengebieden }\end{array}$ \\
\hline Gewassen & $\begin{array}{l}\text { - Meer gebruik van grasklaver } \\
\text { - Verdere verbetering van de } \\
\text { bemestingsefficiëntie, } \\
\text { productiviteit van land, en } \\
\text { ruwvoerconservering (goede } \\
\text { landbouwpraktijken) } \\
\text { - Kortere periode van mest uitrijden } \\
\text { - Voertekorten door weersextremen worden } \\
\text { voorkomen }\end{array}$ & $\begin{array}{l}\text { - Hogere productiviteit door hogere } \\
\text { temperaturen en } \mathrm{CO}_{2} \text { concentraties wordt } \\
\text { benut. } \\
\text { - Productieverliezen door klimaatextremen en } \\
\text { gewasbelagers worden voorkomen (mitigatie } \\
\text { door adaptatie). }\end{array}$ \\
\hline Mest & $\begin{array}{l}\text { - Mest wordt snel verwijderd uit de stal } \\
\text { - Methaanoxidatie (thermisch of microbieel) } \\
\text { van gassen uit mestopslagen buiten de stal } \\
\text { - Koude opslag mest, bij voorkeur o.b.v. } \\
\text { hernieuwbare energie }\end{array}$ & $\begin{array}{l}\text { - Nageschakelde technieken (integreren in } \\
\text { stallenbouw): frequente afvoer mest, gassen } \\
\text { afvangen in gesloten opslag } \\
\text { (oxidatie/vergisting). } \\
\text { - Circulair: nutriënten en zware metalen worden } \\
\text { teruggewonnen } \\
\text { - Eventueel, indien praktijkrijp en geen } \\
\text { afwentelingen, aanzuren mest }\end{array}$ \\
\hline
\end{tabular}

\section{Flexibele planning}

In Figuur 6a zijn maatregelenpakketten uitgezet in de tijd. Hierbij zijn maatregelen die kosteneffectief zijn en geen of weinig afwentelingen als eerste ingezet (categorieën 'laaghangend fruit' en 'lage kosten'). Het implementeren van maatregelen met afwentelingen heeft niet de voorkeur, en zullen pas worden ingezet wanneer alle andere maatregelen onvoldoende zijn. Maatregelen die nog niet praktijkrijp zijn kunnen pas worden ingezet op de langere termijn. In de loop der tijd kunnen hier nieuwe maatregelen bij komen.

In 2030 zijn de pakketten van maatregelen A en B niet langer toereikend om de beleidsdoelstellingen van 2050 te behalen (getoond als 'kantelpunt' in Figuur 6a), en zijn additionele maatregelen nodig. Op dat moment zal de voorkeur uitgaan naar het aanspreken van praktijkrijpe maatregelen in pakket $E_{\text {, }}$ omdat maatregelen in pakket $C$ en $D$ te kostbaar zijn of gepaard gaan met afwentelingen. Er kan interactie plaatsenvinden tussen maatregelen. Zo kan mestvergisting bijvoorbeeld (kosten-) effectiever zijn wanneer mest snel wordt afgevoerd uit de stal, omdat dan meer koolstof in de mest bewaard blijft. Naar verwachting zullen er nieuwe maatregelen beschikbaar komen (pakket E) die in de periode na 2030 kunnen worden ingezet. 


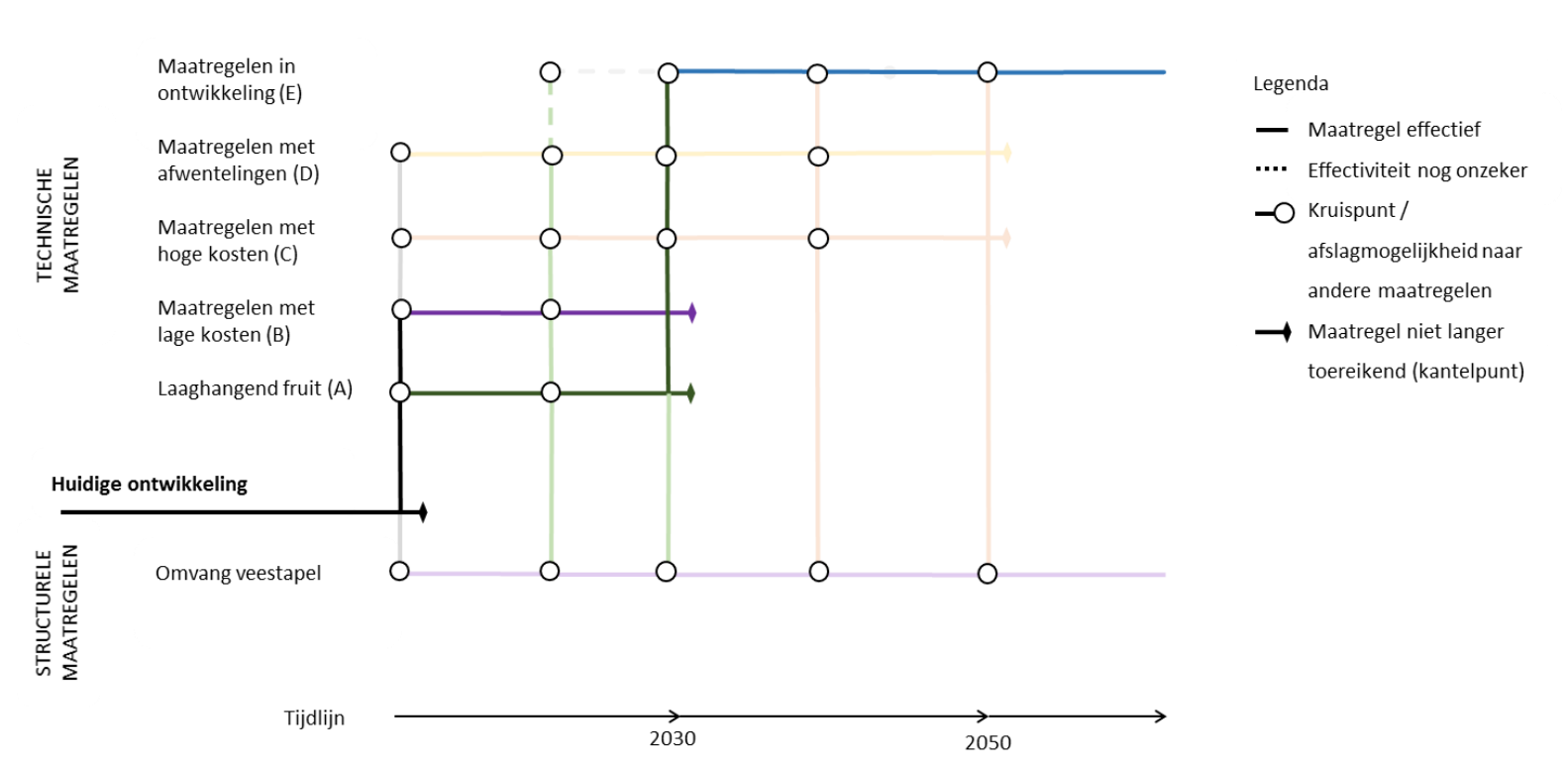

Figuur 6a. Voorkeursroute (donkere lijnen) in de routekaart voor implementatie van mitigatiemaatregelen in de melkveehouderij (afgeleid van Haasnoot et al., 2013). In de voorkeursroute worden eerst technische maatregelenpakketten met geen of lage kosten ( $A$ en $B$ ) ingezet om de emissiereductiedoelstelling voor 2030 te behalen. Voor de doelstellingen van 2050 zullen deze maatregelenpakketten niet langer toereikend zijn (kantelpunt), en zullen andere maatregelenpakketten worden aangesproken. Indien blijkt dat met de voorgestelde route onvoldoende reductie wordt behaald, moet de voorkeursroute worden bijgesteld en zal eerder afgeslagen worden naar pakket $C, D$ of $E$, of naar structurele maatregelen (inkrimpen veestapel).

In de voorkeursroute ${ }^{12}$ in Figuur 6a (aangegeven met een donkere lijn) wordt ervan uitgegaan dat met technische maatregelen zonder afwentelingen emissiereductiedoelstellingen voor 2030 en 2050 kunnen worden behaald. Er moet worden afgeweken van de voorkeursroute indien blijkt dat i) met de voorgestelde route onvoldoende reductie wordt behaald, of ii) veranderingen in externe factoren ervoor zorgen dat de voorgenomen route niet langer mogelijk is. In dit geval zal de voorkeursroute moeten worden bijgesteld en eerder worden afgeslagen naar pakket C, D of E, of door de veestapel in te krimpen (alternatieve routes zijn aangegeven met lichte lijnen in Figuur 6a, met tussentijdse afslagmogelijkheden naar andere pakketten). Een voorbeeld van een nieuwe route is gegeven in Figuur 6b.

\footnotetext{
${ }^{12}$ De voorkeursroute in een routekaart kan ook op basis van andere criteria worden gevormd, bijvoorbeeld wanneer maatregelen tevens moeten bijdragen aan biodiversiteit. Een routekaart kan gebruikt worden op verschillende niveaus (bijv. sector, regio). Op basis van voorkeuren en bezwaren van stakeholders kunnen voorkeursroutes worden geselecteerd.
} 


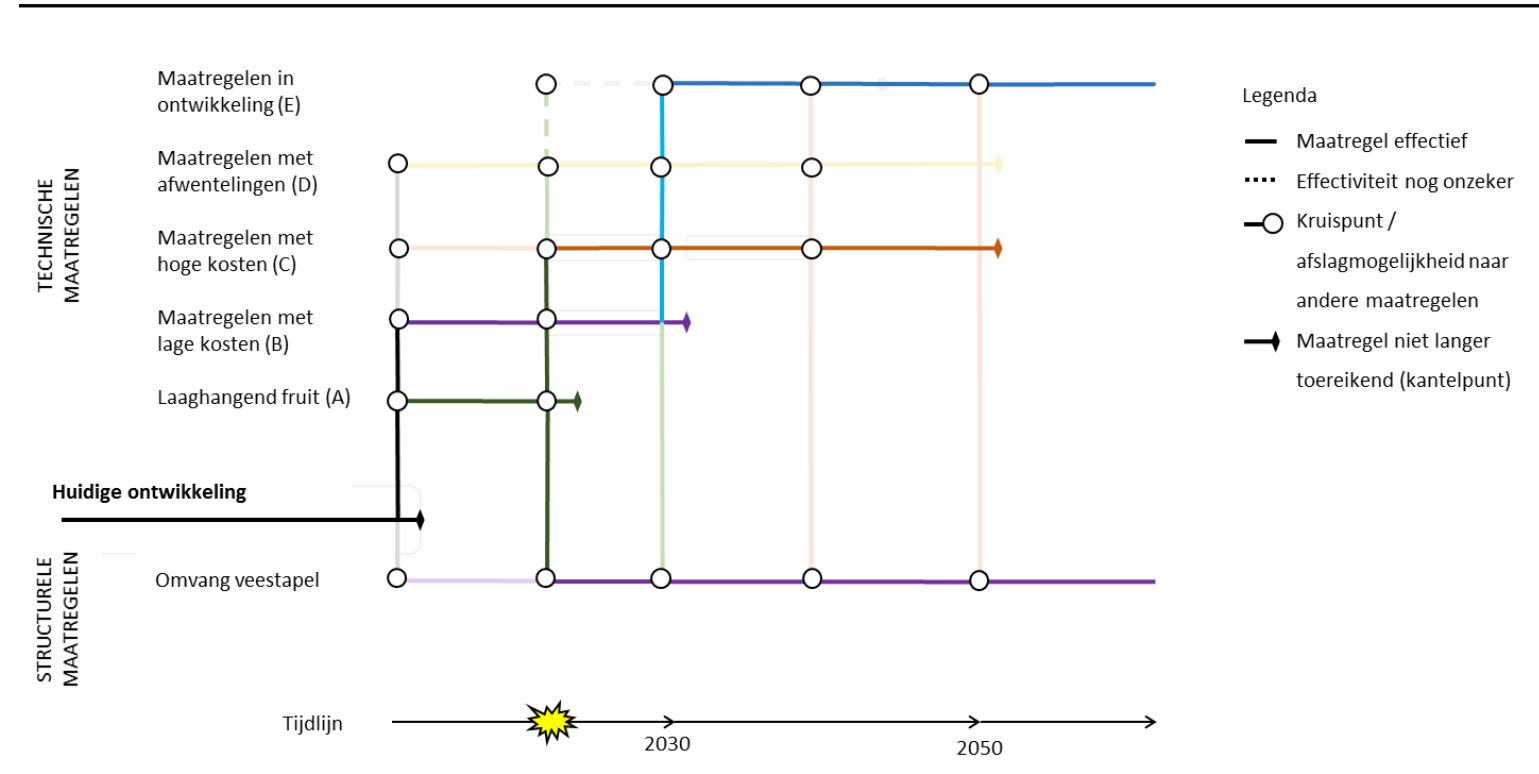

Figuur 6b. Voorbeeld van een alternatieve route (donkere lijnen) voor implementatie van mitigatiemaatregelen in de melkveehouderij (afgeleid van Haasnoot et al., 2013). In de voorkeursroute worden niet alleen technische maatregelenpakketten met geen of lage kosten ( $A$ en $B$ ) ingezet, maar wordt rond het jaar 2025 tevens duurdere technische maatregelen ingezet en structurele maatregelen die de omvang van de veestapel reduceren, om aan de emissiereductiedoelstelling van 2030 te voldoen.

\subsubsection{Adaptatie}

Omdat bij adaptatie de keuze van maatregelen meer afhankelijk is van de locatie (bijv. grondsoort) en het bedrijfstype (bijv. intensiteit), in combinatie met specifieke klimaatrisico's, is een routekaart uitgewerkt voor bedrijven op droogtegevoelige gronden (komklei, zand) in relatie tot het toenemende risico op langdurige droogte. Verwacht wordt dat het gemiddeld hoogste neerslagtekort gedurende het groeiseizoen toeneemt met maximaal 30\% in 2050 en maximaal 50\% in 2080 t.o.v. 1981-2010 (KNMI scenario's).

\section{Droogtemaatregelen}

De te verwachten toename van langdurige droge perioden zal melkveehouders er toe bewegen om maatregelen te nemen die de blootstelling en gevoeligheid voor droogte verminderen. Een voor de hand liggende maatregel is het toepassen van beregening. In de melkveehouderij gebeurt dit al op uitgesproken droogtegevoelige zandgronden in het oostelijk en zuidelijk zandgebied. Vrijwel jaarlijks ligt hier de grasproductie door droogte gedurende kortere of langere tijd helemaal stil. Na de droge zomer van 1976 is op grote schaal in beregening geïnvesteerd. Beregening wordt ingezet om het risico op voertekort te verminderen en om de kwaliteit van de graszode (botanische samenstelling) langer op peil te houden. Herinzaai brengt namelijk hoge kosten met zich mee en geeft risico op nutriëntenverlies. Een keerzijde van beregening als maatregel is dat, wanneer droogte algemeen voorkomt en langer gaat aanhouden, waterschappen het onttrekken van grond- en oppervlakte water voor beregening aan banden leggen om te grote aanspraak op grond- en oppervlaktewater te voorkomen. Beregening is dus geen maatregel waarmee toenemende droogte gecompenseerd kan worden. Mogelijk zou in de toekomst het toepassen van beregenen op grasland meer gericht moeten zijn op het voorkomen van herinzaai.

Het verbeteren van de bodemstructuur bevordert de infiltratie van neerslag in de bodem. Daarmee wordt meer water vastgehouden (minder afspoeling) en is meer water voor gewasgroei beschikbaar. Bovendien zorgt een verbetering van de bodemstructuur voor een grotere worteldiepte, waardoor de vochtbeschikbaarheid toeneemt en de droogtegevoeligheid afneemt. Het vergt in z'n algemeenheid 
veel aandacht en vakmanschap om de bodemstructuur op een voldoende peil te brengen en te houden, vooral als het gaat om het opheffen van storende lagen en bodemverdichtingen. Dat laatste is met steeds groter en zwaarder wordende trekkers en machines een lastige opgave. Het merendeel van de minerale gronden blijkt verdicht te zijn (Van den Akker et al., 2015). De eerste ervaringen met vaste rijpaden in de melkveehouderij worden op dit moment opgedaan, en een volgende stap is om met kleine robots te oogsten.

Een verhoging van het organische stofgehalte op minerale gronden draagt in z'n algemeenheid bij aan het verbeteren van de bodemstructuur en verhoogt enigszins de vochtbeschikbaarheid. Vanuit het perspectief van akkerbouwmatige teelten draagt het telen van gras zowel bij aan het verhogen van het organische stofgehalte als het verbeteren van de bodemstructuur. Een nauwe vruchtwisseling van gras met akkerbouwgewassen (1:3) kan de conditie en het organische stofgehalte van de bodem onder akkerbouw op peil houden. Op termijn is een goede bodemconditie met voldoende organische stof gehalte een vereiste om gewassen door middel van een grotere worteldiepte weerbaarder te maken tegen langdurige droge perioden, aangezien het kunnen toepassen van beregening niet altijd meer van zelfsprekend zal zijn.

Daar waar op droogtegevoelige gronden het gras op termijn mogelijk onvoldoende in de voerbehoefte voorziet, kan de noodzaak ontstaan om een deel van het grasareaal te vervangen door droogte resistente gewassen. De opbrengsten zijn lager, maar de opbrengstzekerheid is groter. Soortenrijk gras of mengteelten kunnen onder moeilijke omstandigheden hogere opbrengsten geven dan monoculturen. Met droogteresistente gewassen en mengteelten moet eerst nog meer ervaring worden opgegaan om te weten wanneer deze het beste toegepast kunnen worden en hoe deze het beste ingepast kunnen worden in de bedrijfsvoering. Modelmatige bedrijfsberekeningen kunnen helpen om te bepalen wanneer de keuze voor dergelijke gewassen een beter resultaat geven dan de huidige situatie. Snijmaïs is een gewas dat zeer efficiënt met water omgaat (C4 gewas) en overtreft de droge stofopbrengst van gras ruimschoots. Het is echter gevoelig voor droogte op het moment van bloei, kolfzetting en korrelvulling. Zonder goede kolfontwikkeling gaat een groot deel van de hoge potentiële voederwaardeopbrengst verloren.

Op minder droogtegevoelige gronden, waar in het winterhalfjaar of langer oppervlaktewater beschikbaar is, kunnen stuwen en drainage er toe bijdragen het water vast te houden. Dit kan vroeg in het voorjaar het risico op vernatting vergroten en tot wateroverlast leiden. Dit kan betekenen dat ten behoeve van waterconservering concessies gedaan moeten worden. Voor wat betreft de hoofdwatergangen, vraagt dit om afwegingen van het waterschap. Als het gaat om de haarvaten van het watersysteem kunnen bedrijven hier zelf beslissingen in nemen door met stuwtjes te gaan werken (agrarisch stuwpeilbeheer). In de bodem kan water vast gehouden worden door peilgestuurde drainage toe te passen. Hierbij is de uitstroom van water op één centraal punt geregeld. Bij voldoende beschikbaarheid van oppervlaktewater kan een dergelijk drainagesysteem ook gebruikt worden voor infiltratie. Bestaande diepgelegen drainage, uitsluitend bedoeld om water af te voeren, zou vervangen moeten worden door ondiepe drainage of peilgestuurde drainage.

Om lange droge periodes te overbruggen wordt aangeraden om te kunnen beschikken over een voldoende ruwvoervoorraad. Dit kan eigen geteeld voer zijn of voer van derden. Belangrijk is de zekerheid dat over voldoende voer beschikt kan worden. Dit betekent dat in productieve jaren niet alleen voer geproduceerd wordt dat in dat jaar beschikbaar moet zijn, maar ook voer ter compensatie van lagere gewasopbrengsten in minder productieve jaren. Bij actief voorraadbeheer wordt ruwvoer duurzamer geproduceerd dan wanneer men in aangewezen is op het gebruik van beregeningswater. 
Flexibele planning van maatregelen

Wanneer maatregelen uitgezet worden in de tijd (Figuur 7) is de verwachting dat huidige strategieën niet toereikend zullen zijn om langere perioden van droogte te kunnen overbruggen, en additionele maatregelen nodig zijn om droogte het hoofd te kunnen bieden ('kantelpunten' in Figuur 7). Op korte termijn gaat de voorkeur (aangegeven met donkere lijnen in Figuur 7) uit naar waterconservering door het vasthouden van oppervlaktewater (d.m.v. stuwen, daar waar mogelijk) en van water in de bodem door het verbeteren van de bodemstructuur en het toepassen van peilgestuurde drainage. Deze maatregelen zijn kosteneffectief en brengen geen/weinig afwentelingen met zich mee. Waar akkerbouwmatige teelten nodig zijn om in de voerbehoefte te voorzien draagt het toepassen van nauwe vruchtwisseling van gras met akkerbouwgewassen bij aan een betere bodemconditie en een hoger organische stofgehalte van bouwland. Hier staat echter wel tegenover dat bij een gelijk aandeel grasland op een bedrijf het organische stofgehalte van grasland daalt. Investeren in beregenen heeft niet de voorkeur omdat beregening door waterschappen aan banden kan worden gelegd, en omdat beregening nu nog hoge kosten en broeikasgasemissies ( $\mathrm{CO} 2)$ met zich meebrengt vanwege het energiegebruik (dat kan veranderen met gebruik van (eigen) hernieuwbare energie). Bovendien, als droogte gepaard gaat met hoge temperaturen, helpt beregening onvoldoende om de productie op peil te houden, zoals dat in de zomer van 2018 het geval was. Wanneer op langere termijn het risico op langdurige droogte verder toeneemt zullen de gekozen maatregelen niet langer toereikend zijn kan worden gekozen voor mengteelten en soortenrijk grasland, en het telen van droogteresistente gewassen. In $z$ 'n algemeenheid verdient het aanbeveling om te kunnen beschikken over een voldoende ruwvoervoorraad. Wanneer klimaatverandering zich sneller voltrekt en langdurige droogte al op in de nabije toekomst frequenter en heviger voorkomt (klimaatscenario B) zijn maatregelen al eerder niet toereikend (kantelpunt) en zullen additionele maatregelen eerder moeten worden ingezet (Figuur 7).

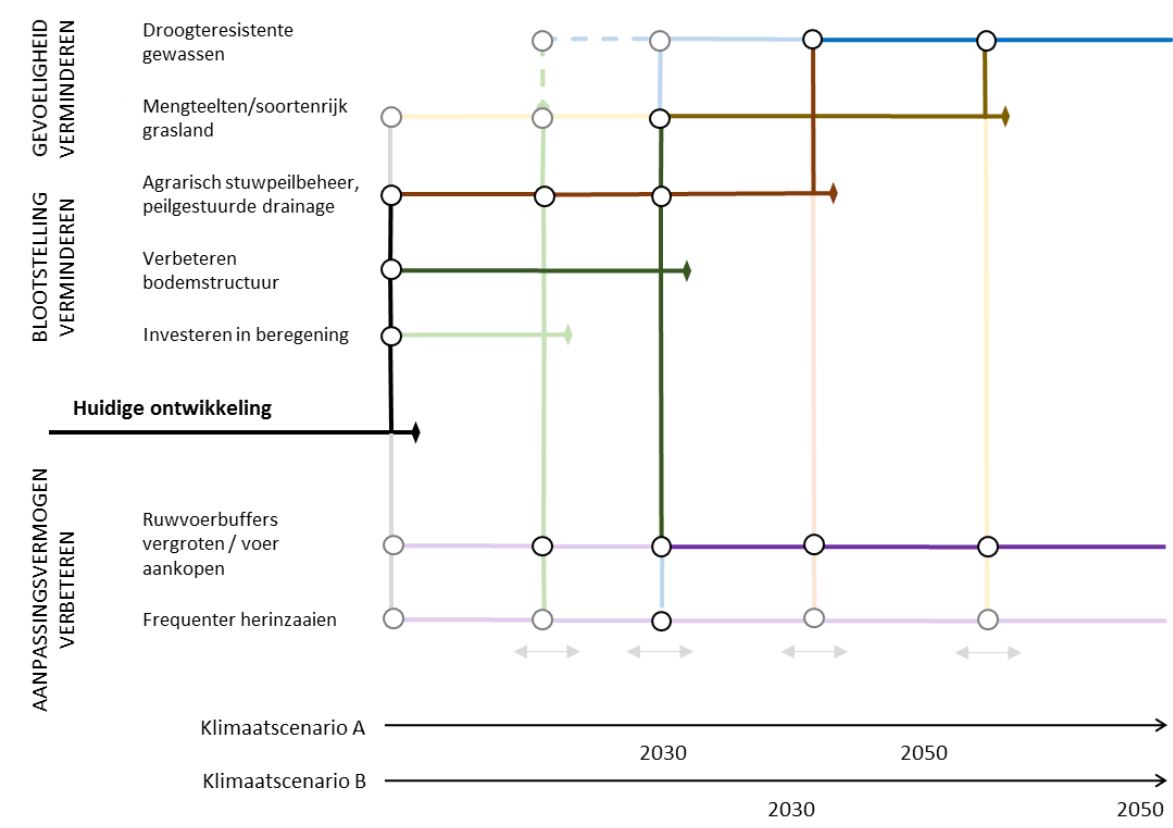

$$
\begin{aligned}
& \text { Legenda } \\
& \ldots \text { Maatregel effectief } \\
& \ldots \text { Effectiviteit nog onzeker } \\
& \text { afuispunt / } \\
& \text { afslagmogelijkheid naar } \\
& \text { andere maatregelen } \\
& \text { Maatregel niet langer } \\
& \text { toereikend (kantelpunt) }
\end{aligned}
$$

Figuur 7. Routekaart voor implementatie van droogtemaatregelen voor bedrijven op droogtegevoelige gronden (methode afgeleid van Haasnoot et al., 2013). Donkere lijnen geven de voorkeursroute aan, waarbij eerst maatregelen worden ingezet die relatief weinig kosten en geen afwentelingen met zich meebrengen. Deze maatregelen zorgen ervoor dat water langer wordt vastgehouden, waardoor planten minder blootgesteld worden aan droogte. Wanneer op termijn het risico op langdurige droogte toeneemt zullen de gekozen maatregelen niet langer toereikend zijn (kantelpunt). Ruwvoerbuffers moeten dan worden vergroot (op bedrijf- en sectorniveau) en maatregelen moeten worden ingezet die de gevoeligheid voor droogte verminderen. 


\subsection{Handelingsperspectieven}

\subsubsection{Sector}

Mitigatie

Er leven nog veel vragen en er is nog veel onbekend onder melkveehouders over mitigatieperspectieven (resultaten stakeholderworkshop; Bijlage 3). Veehouders moeten weten waar ze nu staan, welke maatregelen ze kunnen nemen op hun bedrijf en wat daarvan de verbeterpotentie is. Daarvoor moet intensief aandacht worden besteed aan het vergroten van het bewustzijn van veehouders, zijn instrumenten nodig voor benchmarking in de praktijk (bijv. KringloopWijzer), en is educatie nodig volgens een gestructureerde aanpak gedurende meerdere jaren (niet eenmalig).

Voor individuele bedrijven is het ontwikkelen van een effectieve strategie maatwerk. Maatregelen moeten worden getest in pilots op diverse typen praktijkbedrijven om te weten wat het doorvoeren van maatregelen betekent voor de bedrijfsvoering in breder perspectief, en om eventuele afwentelingen goed in beeld te krijgen (momenteel loopt een pilot op gebied van mitigatie met FrieslandCampina, het is de bedoeling dat verder te verbreden). Afhankelijk van het bedrijfstype (bijv. intensiteit, grondsoort) kunnen maatregelen meer of minder geschikt zijn, en moet een palet aan maatregelen per bedrijfstype worden ontwikkeld en getest in de praktijk (zie Aanbevelingen voor Onderzoek). Uiteindelijk zal ieder bedrijf een passend pakket van maatregelen moeten kiezen. Naast maatregelen die praktijkrijp zijn moet energie worden gezet op veelbelovende maatregelen die nog in ontwikkeling zijn.

Op sector niveau moet worden gestuurd op productievolume, aangezien het totale emissievolume een functie is van het productievolume en emissie intensiteit. De forse reductie in emissie intensiteit die nodig is voor het behalen van reductiedoelstellingen in 2030 kan alleen worden behaald wanneer het productievolume niet substantieel stijgt. Het is verstandig te anticiperen op de situatie waarin onvoldoende reductie wordt behaald door implementatie van technische maatregelen. In dat geval is het inkrimpen van het productievolume mogelijk onvermijdelijk. Op deze situatie moet worden geanticipeerd, inclusief rollen in het vormgeven en aansturen van het proces. Naast maatregelen in relatie tot de omvang van de veestapel moet geanticipeerd worden op omstandigheden die vragen om een herstructurering/-allocatie van de melkveehouderij, zoals ontwikkelingen omtrent verzilting, bodemdaling in veengebieden, regionale adaptatie strategieën, of ontwikkelingen omtrent natuurinclusieve of circulaire landbouw. Dergelijke ontwikkelingen vragen mogelijk andere rollen van melkveehouderijbedrijven dan alleen melkproductie, zoals natuurbeheer, energieproductie, waterberging, of een bijdrage aan emissiereductie op regionaal niveau. Daarnaast kan dit tot reallocatie van bedrijven leiden omdat bepaalde gebieden gunstiger of minder gunstig worden voor de melkveehouderij. Daarnaast kan op gebiedsniveau perceelsruil zorgen voor een betere mix aan droogtegevoelige en vernattingsgevoelige percelen, voor voldoende grasopbrengst in zowel droge als natte jaren.

Activiteiten en (flexibele) planning moeten worden vastgesteld in een gedetailleerd uitvoeringsprogramma voor de melkveehouderijsector, inclusief beoogde resultaten en tijdsplanning, activiteiten/interventies (educatie, pilots, etc.), monitoring en evaluatie (tools), financiële aspecten, communicatie, verantwoordelijkheden van betrokken partijen, procescoördinatie en -beheersing, etc. In het uitvoeringprogramma worden pakketten van mitigatiemaatregelen gefaseerd uitgevoerd richting 2030 en 2050, en is duidelijk zicht op welke additionele maatregelen kunnen worden genomen 
wanneer omstandigheden (bijv. beleid) veranderen of blijkt dat onvoldoende emissiereductie wordt behaald.

\section{Adaptatie}

Het verbeteren van de klimaatbestendigheid van bedrijven vindt op dit moment vooral gefragmenteerd plaats op deelonderwerpen, bijvoorbeeld het anticiperen op klimaatextremen met aanpassingen in waterbeheer, de ontwikkeling van droogteresistente gewassen, of natte teeltsystemen. Deze ontwikkeling moet blijvend ondersteund worden. Daarnaast biedt dit rapport handvatten om de klimaatbestendigheid van bedrijven op meer integrale wijze te verbeteren, door risico's en kansen van klimaatverandering in de volle breedte in beeld te brengen. Bij een meer geïntegreerde aanpak is een bepaalde mate van conceptueel denken en handelen belangrijk, zoals het inbouwen van meer veerkracht in systemen door meer diversiteit (bijv. soortenrijk grasland, vruchtwisseling, combinatie van droge en natte percelen), een hogere weerbaarheid van de onderdelen van het systeem (bijv. weerbaar vee, klimaatbestendige bodems, droogteresistente gewassen), en meer flexibiliteit in de bedrijfsvoering (bijv. ruwvoerbuffers, vergroten van de mestopslag, aanpassen weidegang). Bovendien moet in de aanpak rekening worden gehouden met een onzekere toekomst (bijv. op gebied van klimaat, beleid, sociaaleconomische ontwikkelingen) en is een flexibele planning van maatregelen van belang zodat bedrijven zich bij veranderende omstandigheden relatief eenvoudig kunnen aanpassen.

Een eerste stap richting het integraal verbeteren van de klimaatbestendigheid van bedrijven is de bewustwording over nut en noodzaak van klimaatadaptatie onder veehouders te verhogen. Om dit proces te ondersteunen moeten specifieke klimaatrisico's en -kansen in beeld worden gebracht voor diverse bedrijfstypen en locaties van melkveebedrijven (zie Aanbevelingen voor Onderzoek). Potentiële effecten van klimaatrisico's en -kansen kunnen in scenario's worden doorgerekend voor wat betreft het bedrijfsresultaat, én het effect op emissievolumes. In een tweede stap moeten korte- en lange termijn adaptatiemogelijkheden in beeld worden gebracht voor diverse specifieke bedrijfstypen en locaties van melkveebedrijven. Samen met de ontwikkelrichtingen voor mitigatie resulteert dit in een portfolio van klimaatslimme ontwikkelmogelijkheden, d.w.z. maatregelen die bijdragen aan zowel lage emissies als een verhoogde klimaatbestendigheid. Hierbij moet de focus liggen op langetermijnmaatregelen die meer veerkracht inbouwen in het systeem, waardoor bedrijven minder afhankelijk worden van noodoplossingen zoals beregening, voeraankopen en verzekeringen voor weerschade. Pakketten van maatregelen kunnen verder ontwikkeld worden in pilots. In deze pilots is een integrale aanpak van belang waarbij effecten van maatregelen op andere duurzaamheidsthema's worden meegenomen (bijv. ammoniak).

Veehouders zijn primair zelf verantwoordelijk om met klimaatrisico's om te gaan en adequate maatregelen te treffen om daarop te anticiperen. Er zijn echter maatregelen die een meer sectorbrede aanpak vergen, zoals veredeling, fokkerij, stimuleren van goed bodembeheer en waterbeheer, risicobeheersing in de (internationale) aanvoerketen, concurrentievoordelen door klimaatverandering in het buitenland, en beheersing van (dierlijke/plantaardige) ziekten en plagen. Op sectoraal niveau moet regelmatige herijking van klimaatrisico's en kansen plaatsvinden om tijdig ongunstige ontwikkelingen en kansen te signaleren, en moeten klimaatrisico's en kansen expliciet worden benoemd en meegenomen worden in strategische beslissingen.

Voor diverse aspecten zal de sector in overleg moeten met andere partijen, voor nieuwe vormen van samenwerken, risicodeling, ketenversterking, en het versterken van regionale veerkracht. Zo doet klimaatverandering een verhoogd beroep op peilbeheer en de aanvoer van zoetwater, waarbij 
veehouders lokale aanpassingen en flexibiliteit nodig hebben (maatwerk) terwijl waterschappen robuustere en betaalbare watersystemen nastreven. Overleg is nodig om tot optimale oplossingen te komen (bijv. afspraken over vergoedingen voor ondergelopen grasland om schade elders te voorkomen; Schaap et al. 2014, NAS, 2016). In dit opzicht maken waterschappen in overleg met bedrijfsleven afspraken over het meer klimaatbestendig maken van regionaal waterbeheer (NAS, 2016) en werkt de landbouwsector aan een Deltaplan Agrarisch Waterbeheer gericht op voldoende water van goede kwaliteit. LTO is de aangewezen gesprekspartner richting overheden, waterschappen en bedrijfsleven t.b.v. samenwerking, regelgeving, kennisontwikkeling, en onderzoek.

\subsubsection{Beleid}

Het proces van mitigatie van broeikasgasemissies bevindt zich al in de implementatiefase. Het treffen van maatregelen door melkveehouders kan gestimuleerd worden door middel van voorlichting (melkveehouders en erfbetreders), organiseren van benchmarking, convenanten, en het creëren economische prikkels (bijv. subsidiemaatregelen) en/of verplichtingen. In de Duurzame Zuivelketen wordt emissie intensiteit opgenomen als indicator in het duurzaamheidsprogramma.

Veehouders zijn zelf verantwoordelijk voor het treffen van maatregelen om de risico's van klimaatverandering het hoofd te bieden. Om dit te ondersteunen faciliteert de rijksoverheid in de ontwikkeling van een kennisinfrastructuur (bijv. risicomanagement in de veehouderij, ontwikkelen klimaatslimme veevoergewassen, verbeteren bodemkwaliteit, signalering, monitoring en beheersing van (exotische) (dierlijke/plantaardige) ziekten en plagen) en bestaat er een subsidie op de premie voor de Brede Weersverzekering gericht op de gevolgen van weersextremen. Daarnaast richt het Deltaprogramma Zoet Water (DPZW) zich op adequate zoetwatervoorziening in gebieden. Voorts hebben effecten van klimaatverandering mogelijk gevolgen voor het mestbeleid, als gevolg van de consequenties voor bedrijfsontwikkeling, intensivering en (klimaatbestendige) bodemkwaliteit.

\subsubsection{Onderzoek}

Er vindt al onderzoek plaats en worden doorlopend nieuwe onderzoeksvoorstellen gedaan om de effectiviteit en inpasbaarheid van technische mitigatie- en adaptatiemaatregelen in kaart te brengen (o.a. binnen de Klimaatenvelop landbouw). Voor veel maatregelen is meer onderzoek nodig alvorens deze in de praktijk kunnen worden toegepast. In Bijlage 5 zijn een aantal aanbevelingen voor onderzoek voor de deelonderwerpen in dit rapport opgenomen. Aanbevelingen voor de Klimaatenvelop 2019 zijn hierin niet meegenomen. 


\section{Discussie \& conclusie}

De melkveehouderijsector staat in de komende decennia voor een forse uitdaging om te voldoen aan nationale en Europese beleidsdoelstellingen voor reductie van broeikasgasemissies. Tegelijkertijd zal klimaatverandering de bedrijfsvoering en prestaties van melkveebedrijven in toenemende mate gaan beïnvloeden, zowel positief (bijv. hogere opbrengsten door hogere temperaturen en hogere $\mathrm{CO}_{2}$ concentraties) als negatief (droogte en natschade, plant- en dierziekten).

Dit rapport laat zien dat een groot aantal mitigatie- en adaptatiemaatregelen reeds voorhanden is. De routekaart in dit rapport brengt in beeld hoe deze maatregelen gefaseerd kunnen worden ingezet, om hoge kosten en afwentelingen naar andere duurzaamheidsthema's te voorkomen. Het laat zien hoe een flexibele planning van maatregelen eruit kan zien, waarmee de sector vooruit kan kijken en tijdig de voorkeursroute kan verleggen wanneer omstandigheden daarom vragen. Tegelijkertijd moeten effectieve maatregelen tijdig in beeld worden gebracht, zodat de sector weet waar ze aan toe is. Zo zijn bijvoorbeeld mitigatiemaatregelen rondom mest en huisvesting veelal forse, langetermijn investeringen.

De semi-kwantitatieve aanpak in deze studie is te beperkt om de routekaart concreet vorm te geven. Ten eerste is een kwantitatieve inschatting van emissiereductiepotentieel van maatregelen op sectorniveau nodig om benodigde maatregelen voor 2030 en 2050 te bepalen (bijv. Vellinga et al., in voorbereiding). Daarbij is het nodig te weten hoeveel bedrijven de maatregel kunnen toepassen op het bedrijf (ontsluitingspercentage), en hoe effectief de maatregel is op verschillende typen bedrijven (bedrijfsspecifiek emissiepotentieel). Er moet rekening gehouden worden met de termijn waarop interventies kunnen worden doorgevoerd (bijv. zonnepanelen (snel) versus stallenbouw (langzaam)) en effecttermijn (bijv. koolstofvastlegging in de bodem). Ten tweede moet een uitvoeringsprogramma voor de sector worden ontwikkeld waarin wordt vastgesteld welke stappen nodig zijn om een klimaatslimme melkveehouderij te realiseren, zoals: activiteiten die de bewustwording en kennis in de sector vergroten (communicatie, voorlichting en educatie); activiteiten t.b.v. de ontwikkeling van mitigatie- en adaptatiemaatregelen (onderzoek, pilots); vaststellen van verantwoordelijkheden van betrokken partijen; creëren van stimulansen en een gunstig klimaat voor ontwikkeling (bijv. passend beleid, convenanten, economische prikkels en/of verplichtingen); aanpak omtrent monitoring en evaluatie (incl. benchmarking tools); en vaststellen van plan van aanpak voor implementatie van maatregelen (rolverdelingen, procescoördinatie en -beheersing, financiële aspecten, etc.). De routekaart ontwikkeld in dit rapport kan als uitgangspunt fungeren voor een dergelijk uitvoeringsprogramma.

\section{Integraal klimaatslimme melkveehouderij}

Voor de ontwikkeling naar een integraal klimaatslimme melkveehouderij is het gunstig maatregelen te kiezen die bijdragen aan zowel klimaatmitigatie als -adaptatie. Dit rapport laat zien dat mitigatie- en adaptatiemaatregelen elkaar met name versterken op het vlak van verbetering van bodemkwaliteit en het verhogen van de diversiteit in tijd en ruimte. Concreet betekent dit o.a. meer gebruik van vlinderbloemigen, minder kerende grondbewerking, verbeterde vruchtwisseling (gras met mais en akkerbouwgewassen), en verbeterde waterhuishouding, m.n. in veenweidegebieden. Voor zowel klimaatbestendigheid als emissie intensiteit blijft efficiënt gebruik van productiemiddelen van belang (i.e. goede landbouwpraktijken; bijv. goede ruwvoerconservering, dierziektepreventie). Bij het 
inpassen van mitigatiemaatregelen op de korte termijn moet rekening worden gehouden met interventies die nodig zijn om in te spelen op klimaatverandering op de langere termijn, zoals voldoende mestopslagcapaciteit.

Een gebrek aan klimaatbestendigheid kan ook leiden tot een hogere emissie intensiteit. Dit komt doordat weersextremen (plantaardige en dierlijke) opbrengsten en efficiëntie in de sector negatief kunnen beïnvloeden en daarmee de emissie intensiteit. Anderzijds biedt klimaatverandering ook kansen voor hogere opbrengsten, waardoor de emissie intensiteit kan dalen. Mitigatiemaatregelen die op de korte termijn door veehouders zullen worden genomen kunnen bijdragen of juist ten koste gaan van de klimaatbestendigheid van bedrijven, wat op zijn beurt ook de emissie intensiteit beïnvloedt. Veranderingen in het klimaat kunnen emissies ook rechtstreeks beïnvloeden, zoals een snellere inklinking en oxidatie van veenbodems en een sterkere methaanvorming in mestopslagen bij hogere temperaturen.

\section{Ontwikkeling van een visie op klimaatslimme melkveehouderij}

Deze studie biedt diverse aanknopingspunten voor ontwikkeling van een visie op klimaatslimme melkveehouderij in 2030 en 2050. Een groot aantal maatregelen voor mitigatie en adaptatie is in kaart gebracht, alsook de kosteneffectiviteit, praktijkrijpheid, en interacties met andere thema's. Uitgangspunten voor een langetermijnvisie op klimaatslimme melkveehouderij zouden kunnen zijn:

Mitigatie:

- Ambitie: Een langetermijnverkenning van het emissiereductiepotentieel van de landbouwsector (Vellinga et al., in voorbereiding) schat in dat een halvering van de emissies mogelijk is bij een gelijkblijvend productievolume. Voor methaan en lachgas emissies (bemesting, bodem, dier) is volledige eliminatie van emissies niet mogelijk, maar zouden ambities kunnen worden gesteld op 50 - 75 \% reductie t.o.v. van de huidige emissies. Voor emissies die gerelateerd zijn aan fossiele energiegebruik en mestopslag kan de ambitie worden gesteld op een reductie van $100 \%$.

- Integraliteit: De sector moet er naar streven dat klimaatslimme maatregelen niet ten koste gaan van - en bij voorkeur een gunstige interactie hebben met - andere duurzaamheidsthema's en klimaatbestendigheid van bedrijven. Dit rapport laat zien dat er kansen liggen om met klimaatslimme maatregelen gelijktijdig winst te boeken op andere duurzaamheidsthema's (biodiversiteit, ammoniakemissie, bodemkwaliteit, water, etc.). Ook sluiten verschillende maatregelen goed aan op andere actuele thema's zoals grondgebondenheid, natuur en biodiversiteit, bodemkwaliteit, en bodemverdichting.

- $\quad$ Rol in de regio en in het voedselsysteem: Ook op een hoger niveau (bijv. regionaal, voedselsysteem) moet de melkveehouderij een rol gaan vervullen in het verlagen van broeikasgasemissies door het beschikbaar maken van kwalitatief goede meststoffen (ter vervanging van kunstmest, en ten behoeve van de bodemkwaliteit), biomassa voor de biobased economy, het benutten van blijvend grasland en reststromen die niet door de mens geconsumeerd kunnen worden, en de productie van hernieuwbare energie, waterbuffering en berging, en natuurbeheer. De sector moet ervoor zorgdragen dat er geen afwentelingen zijn van emissies naar andere onderdelen van de keten of naar andere sectoren, lokaal en internationaal.

Adaptatie:

- Wat betreft de klimaatbestendigheid van melkveebedrijven kan door tijdig in te spelen op klimaatverandering negatieve effecten van veranderende weersomstandigheden (droogte, hitte, wateroverlast, ziektedruk) zoveel mogelijk worden voorkomen. Indien het bedrijf toch wordt getroffen bezit het voldoende aanpassingsvermogen om te herstellen. Ook kan het 
bedrijf zich gemakkelijk aanpassen aan veranderende omstandigheden. Kansen die ontstaan door klimaatverandering worden optimaal benut. Op regionaal niveau draagt het bedrijf bij aan het voorkomen van wateroverlast en droogte ('klimaatslim landschap'; FAO, 2013). Een precies beeld van de toekomst is moeilijk te bepalen, aangezien scenario's onderhevig zijn aan veel onzekerheid en de analyse van effecten van klimaatverandering op de veehouderij complex is.

Een relevante vraag voor de gewenste ontwikkelrichting van de melkveehouderij is of een verdere verhoging van de efficiëntie en de productiviteit van dieren ten koste kan gaan van de klimaatbestendigheid van bedrijven. Deze vraag is niet eenvoudig te beantwoorden. Theoretische benaderingen laten zien dat specialistische systemen weliswaar bijzonder goed functioneren wanneer er weinig verstoringen vanuit de omgeving zijn (zoals weersextremen), maar dat ze bij veel verstoringen minder goed functioneren dan systemen die aan verstoringen gewend zijn (Ten Napel et al., 2011). Ook op dierniveau zijn genetisch gezien relaties tussen productie en veerkracht meestal negatief, en is de variantie in melkproductie vaak hoger bij een hogere melkproductie, wat aangeeft dat het dier minder veerkrachtig is (schriftelijke communicatie Han Mulder, juni 2018; Elgersma et al., 2018; Carabano et al, 2016). Er zijn studies waaruit blijkt dat hoogproductieve bedrijven meer kreupele dieren en meer wrak vee hadden dan bedrijven met lagere producties (bijv. Bowell et al., 2003; Rutherford et al., 2009; Cox et al., 1986; Green et al., 2008), maar een causaal verband is daarmee niet aangetoond. In de (fenotypische) praktijk zal in een milieu met veel verstoringen een veerkrachtige koe juist een stabiele melkproductie laten zien, zonder perioden met sterke terugval. 


\section{Literatuur}

Akker, J. J. H. v. d. and R. F. A. Hendriks. 2017. Diminishing peat oxidation of agricultural peat soils by infiltration via submerged drains.

Bertocchi, L., A. Vitali, N. Lacetera, A. Nardone, G. Varisco, and U. Bernabucci. 2014. Seasonal variations in the composition of Holstein cow's milk and temperature-humidity index relationship. Animal 8: 667-674.

Caubel, G. and R. Rivoal. 1972. Observations on attacks of two nematodes harmful to maize in 1971. Phytoma 24: 15-18.

Coenen, P. W. H. G., C. W. M. Van der Maas, P. J. Zijlema, E. J. M. M. Arets, K. Baas, A. C. W. M. Van den Berghe, M. M. Nijkamp, E. P. Van Huis, G. Geilenkirchen, C. W. Versluijs, R. Te Molder, R.

Dröge, J. A. Montfoort, C. J. Peek, J. Vonk, and S. Oude Voshaar. 2016. Greenhouse gas emissions in the Netherlands 1990-2014. National Inventory Report 2016. RIVM Report 2016-0047. National Institute for Public Health and the Environment (RIVM), Bilthoven, the Netherlands.

Csete, M. E. and J. C. Doyle. 2002. Reverse engineering of biological complexity. Science (New York, N.Y.) 295: 1664-1669.

Das, R., L. Sailo, N. Verma, P. Bharti, J. Saikia, Imtiwati, and R. Kumar. 2016. Impact of heat stress on health and performance of dairy animals: A review. Vet. World 9: 260-268.

De Boer, H. and S. Radersma. 2011. Verzilting in Nederland: oorzaken en perspectieven. Wageningen UR Livestock Research Rapport 531. Wageningen UR Livestock Research Lelystad.

de Haas, Y., P. C. Garnsworthy, B. Kuhla, E. Negussie, M. Pszczola, E. Wall, and J. Lassen. 2016. Genetic control of greenhouse gas emissions. Advances in Animal Biosciences 7: 196-199.

De Vries, J. W. 2014. From animals to crops - Environmental consequences of current and future strategies for manure management (PhD thesis). in Animal Production Systems. Wageningen UR, Wageningen.

Del Prado, A., A. Van den Pol-van Dasselaar, D. Chadwick, T. Misselbrook, D. Sandars, E. Audsley, and M. R. Mosquera-Losada. 2015. Synergies between mitigation and adaptation to climate change in grassland based farming systems. JPI FACCE-MACSUR report.

Deru, J. G. C., H. A. v. Schooten, H. F. Huiting, and R. Y. v. d. Weide. 2015. Reduced tillage for silage maize on sand and clay soils: effect on yield and soil organic matter. Pages 398-400 in Grassland and forages in high output dairy farming systems. Vol. 20. European Grassland Federation EGF.

Doorenbos, J. and A. H. Kassam. 1979. Yield response to water function. FAO Irrigation and Drainage Paper No. 33. FAO, Rome.

Doornewaard, G. J., J. W. Reijs, A. C. G. Beldman, J. H. Jager, and M. W. Hoogeveen. 2017. Sectorrapportage Duurzame Zuivelketen; Prestaties 2016 in perspectief. Rapport 2017-087. Wageningen Economic Research, Wageningen.

Eekeren, N. v., J. d. Wit, A. Evers, and M. d. Haan. 2018. Verandering landgebruik voor bodemkwaliteit ook winstgevend voor intensieve bedrijven-. V-focus 15: 32-34.

Ewert, F., M. D. A. Rounsevell, I. Reginster, M. J. Metzger, and R. Leemans. 2005. Future scenarios of European agricultural land use: I. Estimating changes in crop productivity. Agriculture, Ecosystems \& Environment 107: 101-116.

FAO. 2013. Climate-Smart Agriculture Sourcebook. Food and Agriculture Organization, Rome, Italy.

FAO. 2016. Climate change and food security: risks and responses. Food and Agriculture Organization, Rome, Italy.

Gauly, M., H. Bollwein, G. Breves, K. Brugemann, S. Danicke, G. Das, J. Demeler, H. Hansen, J. Isselstein, S. Konig, M. Loholter, M. Martinsohn, U. Meyer, M. Potthoff, C. Sanker, B. Schroder, N. Wrage, B. Meibaum, G. von Samson-Himmelstjerna, H. Stinshoff, and C. Wrenzycki. 2013. Future consequences and challenges for dairy cow production systems arising from climate change in Central Europe - a review. Animal 7: 843-859.

Gerber, P., T. Vellinga, C. Opio, and H. Steinfeld. 2011. Productivity gains and greenhouse gas emissions intensity in dairy systems. Livestock Science 139: 100-108.

Gitz, V. and A. Meybeck. 2012. Risks, vulnerabilities and resilience in a context of climate change. in Proceedings of a Joint FAO/OECD Workshop 23-24 April 2012: Building resilience for adaptation to 
climate change in the agriculture sector. Food And Agriculture Organization Of The United Nations and Organisation For Economic Co-Operation And Development. FAO, Rome.

Goselink, R. M. A., L. B. Sebek, G. J. Hilhorst, A. G. Evers, and M. H. A. d. Haan. 2014. Inpassen van maatregelen ter reductie van gasvormige emissies in de bedrijfsvoering van melkveebedrijven : Koeien \& Kansen resultaten 2010-2012. Wageningen UR Livestock Research, Wageningen.

Groenestein, C. M., J. Mosquera Losada, and S. v. d. Sluis. 2012. Emission factors for methane and nitrous oxide from manure management and mitigation options. Journal of integrative Environmental Sciences 9: 139-146.

Haasnoot, M., H. Middelkoop, E. van Beek, and W. P. A. van Deursen. 2011. A method to develop sustainable water management strategies for an uncertain future. Sustainable Development 19: 369-381.

Haasnoot, M., J. H. Kwakkel, W. E. Walker, and J. ter Maat. 2013. Dynamic adaptive policy pathways: A method for crafting robust decisions for a deeply uncertain world. Global Environmental Change 23: $485-498$.

Hermans, C. M. L., I. R. Geijzendorffer, F. Ewert, M. J. Metzger, P. H. Vereijken, G. B. Woltjer, and A. Verhagen. 2010. Exploring the future of European crop production in a liberalised market, with specific consideration of climate change and the regional competitiveness. Ecological Modelling 221: 2177-2187.

Hirling, W. 1974. Pathogenic nematodes on maize in Baden-Wurttemberg. I. "Toppling disease" of maize due to Ditylenchus dipsaci. Anzeiger-fur-Schadlingskunde-Pflanzen-Umweltschutz 47: 3339.

Hopkins, A. and A. Del Prado. 2007. Implications of climate change for grassland in Europe: impacts, adaptations and mitigation options: a review. Grass and Forage Science 62: 118-126.

Hoving, I. E. and G. L. Velthof. 2006. Landbouw- en milieukundige effecten van graslandvernieuwing op zand- en kleigrond. PraktijkRapport Rundvee 83. Animal Sciences Group / Praktijkonderzoek, Lelystad.

Hoving, I. E., G. André, J. J. H. v. d. Akker, and M. Pleijter. 2008. Hydrologische en landbouwkundige effecten van gebruik 'onderwaterdrains' op veengrond = Hydrological and agricultural effects of the use of submerged drains on peatsoil. Animal Sciences Group, Lelystad.

Hristov, A. N., J. Oh, C. Lee, R. Meinen, F. Montes, T. Ott, J. Firkins, A. Rotz, C. Dell, A. Adesogan, W. Yang, J. M. Tricarico, E. Kebreab, G. Waghorn, J. Dijkstra, S. J. Oosting, P. J. Gerber, B. Henderson, and H. Makkar. 2013. Nutritional and Management Strategies to Mitigate Animal Greenhouse Gas Emissions (Conference paper).

Huiting, H. F., R. Y. v. d. Weide, M. A. Schoutsen, and J. J. d. Haan. 2016. Bodem onder een duurzame en renderende maïsteelt : Hoe onderzoek bijdraagt aan een duurzame maïsteelt, met oog voor bodemkwaliteit én rendement. Beter Bodembeheer, Lelystad.

IPCC. 2012. Managing the risks of extreme events and disasters to advance climate change adaptation (SREX). Special Report of the Intergovernmental Panel on Climate Change (IPCC). IPCC, Geneva.

Izaurralde, R. C., A. M. Thomson, J. A. Morgan, P. A. Fay, H. W. Polley, and J. L. Hatfield. 2011. Climate Impacts on Agriculture: Implications for Forage and Rangeland Production. Agron. J. 103: 371-381.

Jansen, P. C., R. F. A. Hendriks, and C. Kwakernaak. 2009. Behoud van veenbodems door ander peilbeheer : maatregelen voor een robuuste inrichting van het westelijk veenweidegebied. Alterrarapport;2009. Alterra, Wageningen.

Juroszek, P. and A. von Tiedemann. 2015. Linking Plant Disease Models to Climate Change Scenarios to Project Future Risks of Crop Diseases: A Review. Journal of Plant Diseases and Protection 122: 3-15.

Kipling, R. P., P. Virkajärvi, L. Breitsameter, Y. Curnel, T. De Swaef, A.-M. Gustavsson, S. Hennart, M. Höglind, K. Järvenranta, J. Minet, C. Nendel, T. Persson, C. Picon-Cochard, S. Rolinski, D. L. Sandars, N. D. Scollan, L. Sebek, G. Seddaiu, C. F. E. Topp, S. Twardy, J. Van Middelkoop, L. Wu, and G. Bellocchi. 2016. Key challenges and priorities for modelling European grasslands under climate change. Science of The Total Environment 566-567: 851-864.

Kjøhl, M., A. Nielsen, and N. C. Stenseth. 2011. Potential effects of climate change on crop pollination. Food and agriculture organization of the united nations, Rome.

Klop, G. 2016. Low Emission Feed : using feed additives to decrease methane production in dairy cows. Wageningen University, Wageningen. 
Korevaar, H. 2016. Mogelijkheden om blijvend grasland in Natura 2000 gebieden te vernieuwen. Wageningen UR, Plant Research International.

Kuikman, P. J., R. L. M. Schils, C. L. Beek, and G. L. Velthof. 2010. Nitrificatieremmers in de Nederlandse landbouw : potentiële vermindering van lachgasemissie. Alterra, Wageningen.

Lamichhane, J. R., M. Barzman, K. Booij, P. Boonekamp, N. Desneux, L. Huber, P. Kudsk, S. R. H. Langrell, A. Ratnadass, P. Ricci, J.-L. Sarah, and A. Messéan. 2015. Robust cropping systems to tackle pests under climate change. A review. Agronomy for Sustainable Development 35: 443459.

Leisova-Svobodova, L., V. Minarikova, L. Kucera, and S. A. Pereyra. 2012. Structure of the Cochliobolus sativus population variability. Plant Pathology 61: 709-718.

Lesschen, J. P., H. Heesmans, J. Mol-Dijkstra, A. Van Doorn, E. Verkaik, I. Van den Wyngaert, and P. J. Kuikman. 2012. Mogelijkheden voor koolstofvastlegging in de Nederlandse landbouw en natuur. Alterra-rapport 2396. Alterra, Wageningen.

Liebman, M. and L. A. Schulte. 2015. Enhancing agroecosystem performance and resilience through increased diversification of landscapes and cropping systems. Elem. Sci. Anth. 3: 41.

Lowen, A. C., S. Mubareka, J. Steel, and P. Palese. 2007. Influenza virus transmission is dependent on relative humidity and temperature. PLoS Pathog. 3: 1470-1476.

Lubroth, J. 2012. Climate change and animal health. Pages 63-70 in Building resilience for adaptation to climate change in the agricultural sector. Proceedings of a joint FAO/OECD workshop 23-24 April, 2012. A. M. J. L. S. R. N. A. V. Gitz, ed. FAO/OECD, Rome.

Maclachlan, N. J., C. E. Mayo, P. W. Daniels, G. Savini, S. Zientara, and E. P. J. Gibbs. 2015. Bluetongue. Rev. Sci. Tech. Off. Int. Epizoot. 34: 329-340.

Mas-Coma, S., M. A. Valero, and M. D. Bargues. 2009. Climate change effects on trematodiases, with emphasis on zoonotic fascioliasis and schistosomiasis. Vet. Parasitol. 163: 264-280.

Massé, D. I., G. Jarret, F. Hassanat, C. Benchaar, and N. M. C. Saady. 2016. Effect of increasing levels of corn silage in an alfalfa-based dairy cow diet and of manure management practices on manure fugitive methane emissions. Agriculture, Ecosystems and Environment 221: 109-114.

Meissle, M., P. Mouron, T. Musa, F. Bigler, X. Pons, V. P. Vasileiadis, S. Otto, D. Antichi, J. Kiss, Z. Pálinkás, Z. Dorner, R. Van Der Weide, J. Groten, E. Czembor, J. Adamczyk, J.-B. Thibord, B. Melander, G. C. Nielsen, R. T. Poulsen, O. Zimmermann, A. Verschwele, and E. Oldenburg. 2010. Pests, pesticide use and alternative options in European maize production: current status and future prospects. Journal of Applied Entomology 134: 357-375.

Melander, B., N. Munier-Jolain, R. Charles, xeb, J. Wirth, J. Schwarz, xfc, rgen, R. van der Weide, L. Bonin, P. K. Jensen, and P. Kudsk. 2013. European Perspectives on the Adoption of Nonchemical Weed Management in Reduced-Tillage Systems for Arable Crops. Weed Technology 27: 231-240.

Mosquera Losada, J., R. L. M. Schils, C. M. Groenestein, P. Hoeksma, G. L. Velthof, and E. W. J. Hummelink. 2010. Emissies van lachgas, methaan en ammoniak uit mest na scheiding = Emissions of nitrous oxide, methane and ammonia from manure after separation. Wageningen UR Livestock Research, Lelystad.

Mostert, P. F. 2018. The impact of diseases in dairy cows on greenhouse gas emissions and economic performance (PhD thesis). Wageningen, the Netherlands.

Napel, J. t., F. J. J. A. Bianchi, and M. W. P. Bestman. 2006. Utilising intrinsic robustness in agricultural production systems. Pages 32-54 in Invention for a sustainable development of agriculture. TransForum, Zoetermeer.

NAS. 2016. Nationale klimaatadaptatie strategie 2016 (NAS). Aanpassen met ambitie. Ministerie van Infrastructuur en Milieu, Den Haag.

NAS. 2018. Uitvoeren met ambitie. Uitvoeringsprogramma 2018 - 2019. Nationale klimaatadaptatiestrategie (NAS). Ministerie van Infrastructuur en Waterstaat, Den Haag.

Newbery, F., A. Qi, and B. D. Fitt. 2016. Modelling impacts of climate change on arable crop diseases: progress, challenges and applications. Current opinion in plant biology 32: 101-109.

Ottaviani, D., S. de la Rocque, S. Khomenko, M. Gilbert, S. H. Newman, B. Roche, K. Schwabenbauer, J. Pinto, T. P. Robinson, and J. Slingenbergh. 2010. The Cold European Winter of 2005-2006 Assisted the Spread and Persistence of H5N1 Influenza Virus in Wild Birds. EcoHealth 7: 226-236.

Paas, W. 2013. Impacts of climate and socio-economic change on economic viability and land use of dairy farms in 'de Baakse Beek', the Netherlands. MSc thesis. Plant Production Systems, Wageningen University, Wageningen. 
Paas, W., A. Kanellopoulos, G. van de Ven, and P. Reidsma. 2016. Integrated impact assessment of climate and socio-economic change on dairy farms in a watershed in the Netherlands. NJAS Wageningen Journal of Life Sciences 78: 35-45.

PBL. 2015a. Aanpassen aan klimaatverandering - Kwetsbaarheden zien, kansen grijpen. PBL (Planbureau voor de Leefomgeving), met medewerking van Kennis voor Klimaat en KNMI, Den Haag.

PBL. 2015b. Wereldwijde klimaateffecten: risico's en kansen voor Nederland. Planbureau voor de Leefomgeving, Den Haag.

Petersen, S. O., A. J. Andersen, and J. Eriksen. 2012. Effects of cattle slurry acidification on ammonia and methane evolution during storage. Journal of environmental quality 41: 88-94.

Petersen, S. O., M. Blanchard, D. Chadwick, A. Del Prado, N. Edouard, J. Mosquera, and S. G. Sommer. 2013. Manure management for greenhouse gas mitigation. Animal 7 Suppl 2: 266-282.

Potts, S. G., V. L. Imperatriz-Fonseca, H. T. Ngo, J. C. Biesmeijer, T. D. Breeze, L. V. Dicks, L. A. Garibaldi, R. Hill, J. Settele, and A. J. Vanbergen. 2016. Assessment report on pollinators, pollination and food production: : summary for policymakers. Intergovernmental Science-Policy Platform on Biodiversity and Ecosystem Services, Bonn, Germany.

Pryce, J. E. and M. J. Bell. 2017. The impact of genetic selection on greenhouse-gas emissions in Australian dairy cattle. Animal Production Science 57: 1451-1456.

Puente-Rodríguez, D. and C. M. Groenestein. in ontwikkeling. Duurzaamheid-ethische toetsing van methaan reducerende technische maatregelen: Evaluatie van technische maatrelen ten aanzien van de integrale verduurzaming van de Nederlandse veehouderij. Wageningen Livestock Research, Wageningen

Razinger, J., V. P. Vasileiadis, M. Giraud, W. v. Dijk, Modic, pela, M. Sattin, and G. Urek. 2016. Onfarm evaluation of inundative biological control of Ostrinia nubilalis (Lepidoptera: Crambidae) by Trichogramma brassicae (Hymenoptera: Trichogrammatidae) in three European maize-producing regions. Pest Management Science 72: 246-254.

Reidsma, P., J. Wolf, A. Kanellopoulos, B. F. Schaap, M. Mandryk, J. Verhagen, and M. K. van Ittersum. 2015. Climate Change Impact and Adaptation Research Requires Farming Systems Analysis and Integrated Assessment: A Case Study in the Netherlands. Procedia Environmental Sciences 29: 286-287.

Riemens, M. M. 2012. Effect of possible climate change on arable weed species emergence in the Netherlands. An exploratory study with 3 case studies: Cirsium arvense, Sonchus arvensis and Galinsoga parviflora. Wageningen UR, Plant Research International, Report 494.

Roetert, H. 2009. Project Klimaat en Koeien in Overijssel. Eindrapportage. Stimuland, Ommen.

Ros, J. and B. Daniëls. 2017. Verkenning van klimaatdoelen. PBL Planbureau voor de Leefomgeving, Den Haag.

Schaap, B. F., M. Blom-Zandstra, C. M. L. Hermans, B. G. Meerburg, and J. Verhagen. 2011. Impact changes of climatic extremes on arable farming in the north of the Netherlands. Regional Environmental Change 11: 731-741.

Schaap, B. F., P. Reidsma, H. Agricola, and A. Verhagen. 2014. Klimaatrisico's en -kansen voor de landbouw. Stichting Dienst Landbouwkundig Onderzoek (DLO) onderzoeksinstituut Plant Research International, Wageningen.

Schils, R. 2002. White clover utilisation on dairy farms in the Netherlands. S.n., S.I.

Schils, R. L. M., D. A. Oudendag, K. W. v. d. Hoek, J. A. d. Boer, A. G. Evers, and M. H. A. d. Haan. 2006. Broeikasgasmodule BBPR. Animal Sciences Group, Lelystad.

Schooten, H. A. v. and A. P. Philipsen. 2012. Grass silage management affecting greenhouse gas emissions and farm economics. Pages 126-127 in Proc. Proceedings XVI International Silage Conference, Helsinki, Finland, 2-4 July 2012.

Scopel, E., B. Triomphe, F. Affholder, F. A. M. Da Silva, M. Corbeels, J. H. V. Xavier, R. Lahmar, S. Recous, M. Bernoux, E. Blanchart, I. de Carvalho Mendes, and S. De Tourdonnet. 2013. Conservation agriculture cropping systems in temperate and tropical conditions, performances and impacts. A review. Agronomy for Sustainable Development 33: 113-130.

Sebek, L. B., J. Mosquera, and A. Bannink. 2016. Rekenregels voor de enterische methaan-emissie op het melkveebedrijf en reductie van de methaan-emissie via mesthandling, het handelingsperspectief van het voerspoor inzichtelijk maken met de Kringloopwijzer. Wageningen Livestock Research, Wageningen. 
Spruijt, J. and A. Terbijhe. 2016. Perspectief zonnestroom in de agrarische sector. ACRRES Wageningen UR, Lelystad.

Staarink, H., M. Arts, I. E. Hoving, and J. Van Bakel. 2014. Monitoringsrapport Landbouw op peil periode 2011-2015.

ten Napel, J., A. A. van der Veen, S. J. Oosting, and P. W. G. G. Koerkamp. 2011. A conceptual approach to design livestock production systems for robustness to enhance sustainability. Livestock Science 139: 150-160.

ter Maat, J., M. an der Vat, J. Hunink, M. Haasnoot, G. Prinsen, M. H. Visser, P. Boderie, R. van Ek, M. Maarse, R. van der Sligte, H. Verheij, and C. Wesselius. 2014. Effecten van maatregelen voor de zoetwatervoorziening in Nederland in de 21e eeuw. Deltares, [Delft].

Van de Wiel, C. C. M., L. Van den Brink, C. B. Bus, M. M. Riemens, L. A. P. Lotz, and M. J. M. Smulders. 2011. Crop volunteers and climate change. Effects of future climate change on the occurrence of maize, sugar beet and potato volunteers in the Netherlands. PPO-PRI, Wageningen.

Van den Akker, J., B. Vermeulen, B. Verwijs, W. De Groot, and M. Pleijter. 2016. Bodemverdichting in de Nederlandse landbouw. Voordracht congres Beter bodem beheer Lunteren http://edepot.wur.nl/393019

Van den Akker, J. J. H., J. Beuving, R. F. A. Hendriks, and R. J. Wolleswinkel. 2007. Maaivelddaling, afbraak en $\mathrm{CO} 2$ emissie van Nederlandse veenweidegebieden, Leidraad Bodembescherming (83). Sdu, Den Haag.

van den Akker, J. J. H., R. F. A. Hendriks, I. E. Hoving, and M. Pleijter. 2010. Toepassing van onderwaterdrains in veenweidegebieden: effecten op maaivelddaling, broeikasgasemissies en het water. Landschap : tijdschrift voor landschapsecologie en milieukunde 27: 136-149.

Van den Akker, J. J. H., R. F. A. Hendriks, and M. Pleijter. 2012. CO2 emissions of peat soils in agricultural use: calculation and prevention. in Proc. 19th Conference of the Int. Soil Tillage Res. Org. www.ISTRO.org

Van den Pol-van Dasselaar, A. 2012. Qualitative overview of mitigation and adaptation options and their possible synergies \& trade-offs. Deliverable 8.1. AnimalChange, seventh framework programme.

Van den Pol, A., H. Blonk, M. A. Dolman, A. G. Evers, M. H. A. De Haan, J. W. Reijs, L. B. Sebek, T. V. Vellinga, and $\mathrm{H}$. Wemmenhove. 2013. Kosteneffectiviteit reductiemaatregelen emissie broeikasgassen zuivel. Wageningen UR Livestock Research, Lelystad.

Van der Fels-Klerx, H. J., P. W. Goedhart, O. Elen, T. Börjesson, V. Hietaniemi, and C. J. H. Booij. 2012. Modeling Deoxynivalenol Contamination of Wheat in Northwestern Europe for Climate Change Assessments. Journal of Food Protection 75: 1099-1106.

Van Middelaar, C. E., P. B. M. Berentsen, J. Dijkstra, and I. J. M. De Boer. 2013. Evaluation of a feeding strategy to reduce greenhouse gas emissions from dairy farming: The level of analysis matters. Agricultural Systems 121: 9-22.

Van Middelaar, C. E., J. Dijkstra, P. B. M. Berentsen, and I. J. M. De Boer. 2014. Cost-effectiveness of feeding strategies to reduce greenhouse gas emissions from dairy farming. Journal of Dairy Science 97: 2427-2439.

Van Zanten, H. H. E., M. Herrero, O. Van Hal, E. Röös, A. Muller, T. Garnett, P. J. Gerber, C. Schader, and I. J. M. De Boer. 2018. Defining a land boundary for sustainable livestock consumption. Global Change Biology 24: 4185-4194.

Vellinga, T., H. van Laar, M. Thomassen, I. de Boer, P. Berkhout, and H. Aiking. 2009a. Milieueffecten van diervoeders. Rapport / Animal Sciences Group, Wageningen UR;205. Wageningen UR, Animal Sciences Group, Lelystad.

Vellinga, T. V., M. H. A. d. Haan, and A. G. Evers. 2009b. Vermindering van de uitstoot van broeikasgassen op het melkveebedrijf : berekeningen voor praktijkbedrijven $=$ Decreasing greenhouse gas emissions on dairy farms. Animal Sciences Group.

Vellinga, T. V. and I. E. Hoving. 2011. Maize silage for dairy cows: mitigation of methane emissions can be offset by land use change. Nutrient Cycling in Agroecosystems 89: 413-426.

Vellinga, T. V. and N. Van Eekeren. 2017. Effect verandering landgebruik op emissies broeikasgassen. V-focus 14 (2). p38-39.

Vellinga, T. V. and M. de Vries. 2018. Effectiveness of climate change mitigation options considering the amount of meat produced in dairy systems. Agricultural Systems 162: 136-144. 
Vellinga, T. V., J. W. Reijs, J. P. Lesschen, and H. Van Kernebeek. in voorbereiding. Langetermijn opties voor reductie van broeikasgasemissies uit de Nederlandse landbouw: een verkenning. Wageningen Livestock Research, Wageningen.

Velthof, G. L., I. E. Hoving, J. Dolfing, A. Smit, P. J. Kuikman, and O. Oenema. 2010. Method and timing of grassland renovation affects herbage yield, nitrate leaching, and nitrous oxide emission in intensively managed grasslands. Nutrient Cycling in Agroecosystems 86: 401-412.

Verloop, K. 2013. Limits of effective nutrient management in dairy farming: analyses of experimental farm De Marke. Wageningen UR, Wageningen.

Verloop, K., R. H. E. M. Geerts, J. Oenema, G. J. Hilhorst, M. H. A. De Haan, and A. Evers. 2013. Gebruik van de dunne en dikke fractie van rundveemest getest op Koeien \& Kansenmelkveebedrijven. Resultaten 2010, 2011 en 2012. Rapport nr. 69. Plant Research International, Wageningen

Verschave, S. H., J. Charlier, H. Rose, E. Claerebout, and E. R. Morgan. 2016. Cattle and Nematodes Under Global Chance: Transmission Models as an Ally. Trends Parasitol. 32: 724-738.

Vickers, M. and E. Berry. 2009. Crop protection priorities for grass and forage crops in light of proposed EU pesticide regulations and other changes. Issued by ADAS UK Ltd. Prepared by: Sarah Wynn, John Garstang, Peter Gladders, Steve Ellis, James Clarke and Susan Twining.

Warner, D., A. Bannink, B. Hatew, H. van Laar, and J. Dijkstra. 2017. Effects of grass silage quality and level of feed intake on enteric methane production in lactating dairy cows1. Journal of Animal Science 95: 3687-3699.

West, J. S., J. A. Townsend, M. Stevens, and B. D. L. Fitt. 2012. Comparative biology of different plant pathogens to estimate effects of climate change on crop diseases in Europe. European Journal of Plant Pathology 133: 315-331.

Willeghems, G., L. De Clercq, E. Michels, E. Meers, and J. Buysse. 2016. Can spatial reallocation of livestock reduce the impact of GHG emissions? Agricultural Systems 149: 11-19.

Wolf, J., M. Mandryk, A. Kanellopoulos, P. Van Oort, B. Schaap, P. Reidsma, and M. Van Ittersum. 2010. Methodologies for analyzing future farming systems and climate change impacts in Flevoland as applied within the AgriAdapt project. Wageningen University and Research centre, Wageningen.

Zijlstra, J., J. J. Poelarends, G. Migchels, and F. A. N. v. Alebeek. 2015. Routekaart biodiversiteit : aanbevelingen voor de aanpak van biodiversiteit binnen de zuivelketen. Wageningen UR Livestock Research, Wageningen. 


\section{Bijlage 1 Interactietabel mitigatiemaatregelen}

Kosteneffectiviteit, praktijkrijpheid, en interacties van mitigatiemaatregelen met andere

duurzaamheidsthema's ${ }^{1}$ (o.b.v. expert opinie). Scores variëren op een schaal van -3 tot +3 , waarbij -3 een negatieve invloed betekent (afwenteling) en +3 een positieve invloed (synergie).

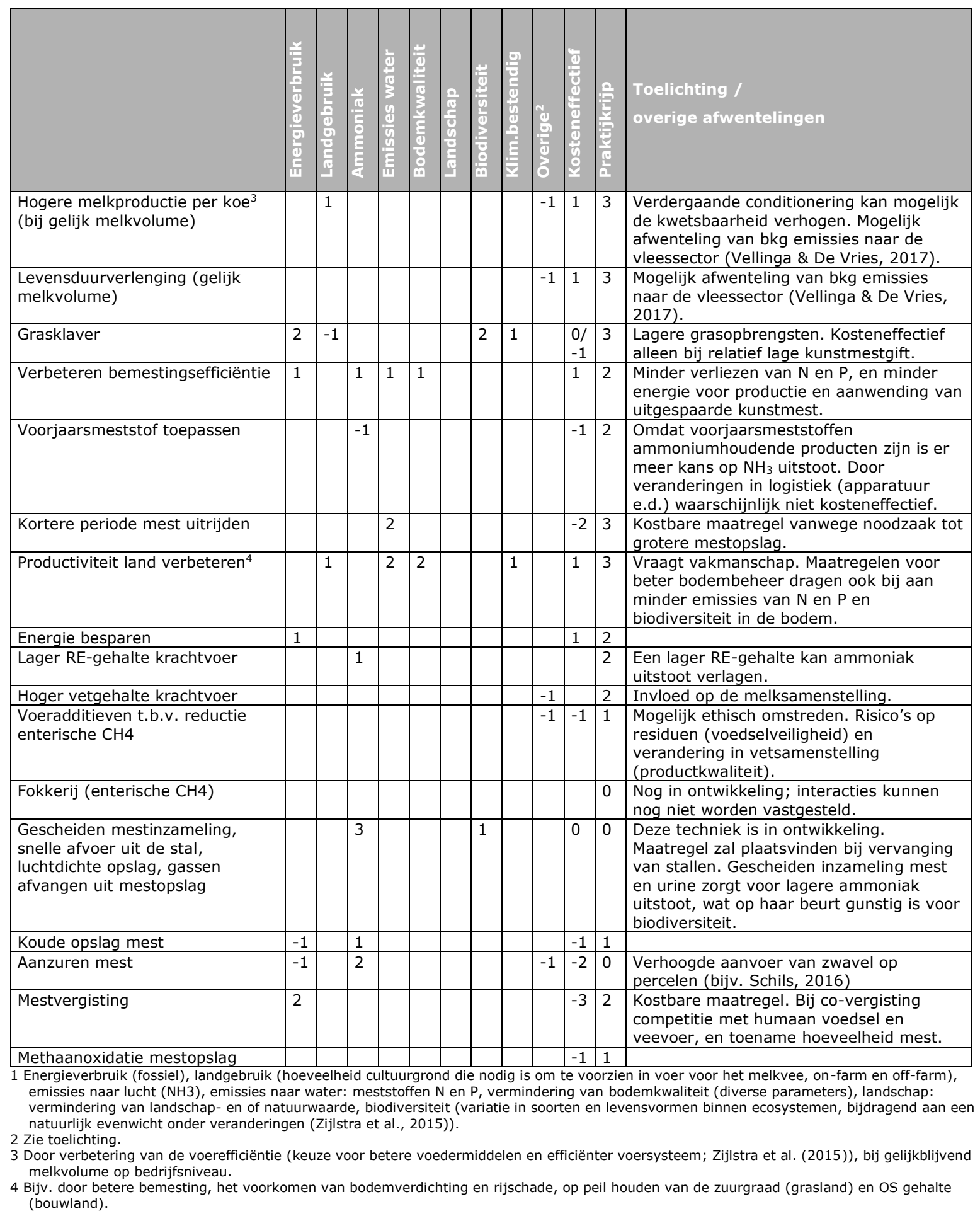




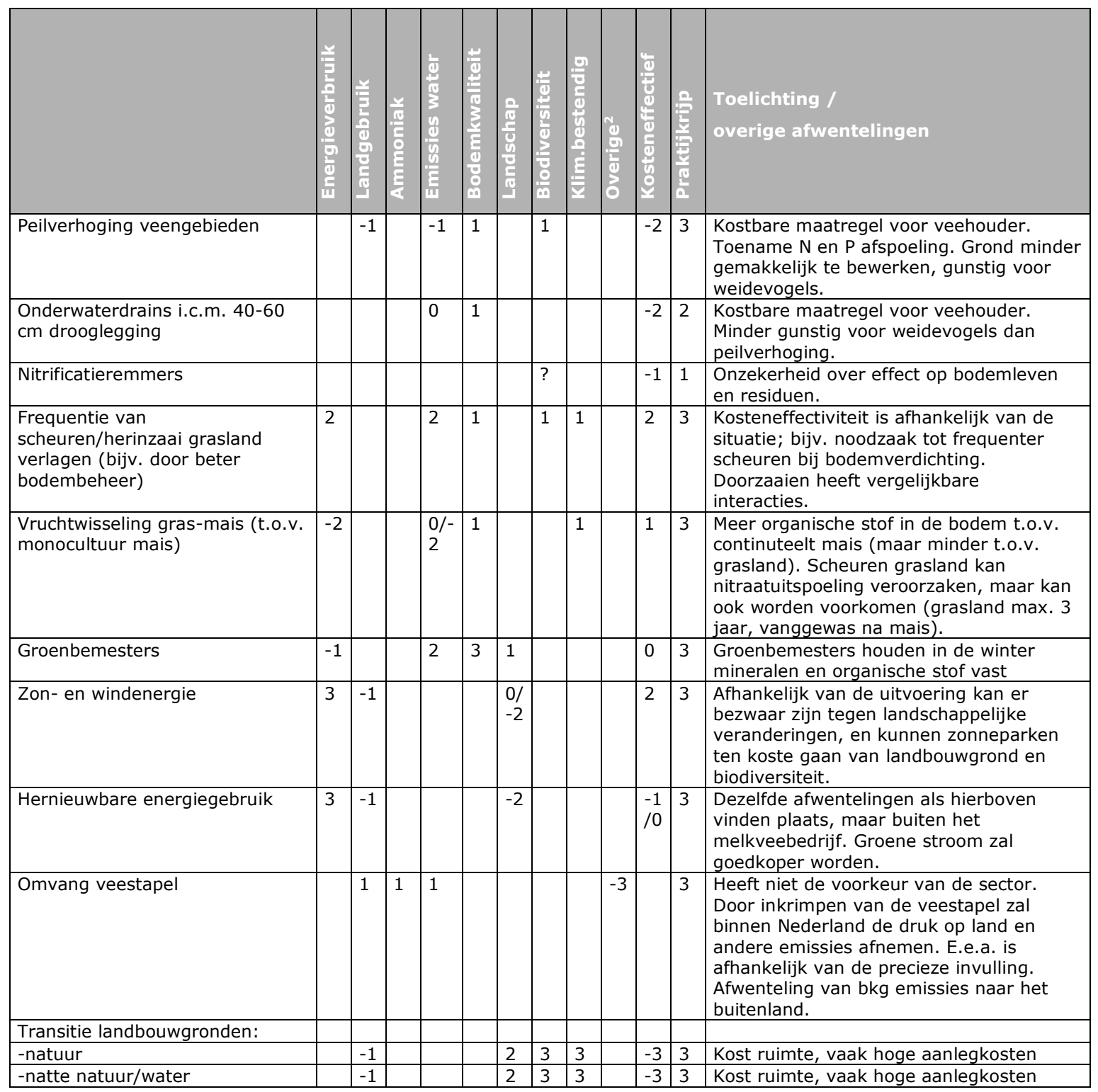




\title{
Bijlage 2 Gewasbeschermings- problematiek en anticiperende maatregelen per gewas
}

\author{
Auteur: Rommie van der Weide (Wageningen Plant Research)
}

\section{Mais}

In een aantal EU projecten werd samengewerkt aan geïntegreerde gewasbescherming in mais en een aantal andere gewassen (www.endure.eu en www.pure.eu). Hiervoor werd de gewasbeschermingsproblematiek in mais in de verschillende regio's in kaart gebracht (Meislle, 2009; Vasileiadas 2011, 2013, 2015, 2016). Op basis hiervan is het mogelijk om aan te geven welke overeenkomsten en verschillen er zijn in de gewasbescherming in maïs vergeleken met de Po vallei in Italië, Zuid West Frankrijk, Hongarije en Spanje. Dit geeft een beeld van hoe onze gewasbescherming in de maïs waarschijnlijk zal veranderen t.g.v. klimaatverandering en wat de kortere termijn anticiperende maatregelen zijn.

Op het grootste deel van het areaal in de hele EU wordt zaadbehandeling met fungiciden toegepast. In 2009 was bladbehandeling met fungiciden niet gebruikelijk met uitzondering van korrelteelt in het zuidwesten van Frankrijk. Daar wordt dit gebruikt tegen bladvlekkenziekte, roest en Fusarium sp. In de zuidelijke landen heeft men last van valse meeldauw veroorzaakt door Sclerophthora spp. en bladvlekken door een Helminthosporium sp. Ook in Engeland verwacht men een toename van bladvlekken en oogvlekken door Kabiella (Vickers, 2009). Jos Groten (mondelinge informatie) ziet toenemende problemen met Rhizoctonia besmettingen en het daardoor pleksgewijs vroeg uitvallen van maïsplanten en maïskopbrand met name op de vochtigere gronden. In de hele EU heeft met last van Fusarium infecties en de mycotoxinen in het geoogste product die daarvan het gevolg zijn. De problematiek in de zuidelijke landen is echter wel groter en neemt toe in zuidwest Duitsland en zuidwest Polen. In Italië zijn de problemen ook nog groter door extra besmetting met een andere schimmelsoort Aspergillus flavus. In Spanje nam de problematiek wat af na gebruik van genetisch gemodificeerd BT mais. Insecten zoals de Europese maisstengelboorder 'Ostrinia nubilalis' en de mediterrane maisboorder 'Sesamia nonagroide' worden hiermee bestreden, waardoor er minder invalspoorten voor de schimmel ontstaan.

De insectenproblematiek is beduidend erger ten zuiden van ons. Voor de incidenten met insecticiden op zaaizaad met consequenties voor de bij, kwam zaaizaadbehandeling met insecticiden veelvuldig voor in de hele EU. In Frankijk en Hongarije wordt op een aanzienlijk deel van het areaal de bodem behandeld met insecticiden. In de gehele EU met uitzondering van de noordelijke landen is een bladbehandeling met insecticiden ook gebruikelijk en in de Po vallei in Italië zelfs twee keer per groeiseizoen. De ritnaalden problematiek neemt toe en bij een vroegere en zich sneller vermeerderende luizenpopulatie doen deze ook schade (mondelinge informatie Jos Groten). De ergste plagen zijn de Europese en de mediterrane stengelboorders en de uit de USA overgekomen in het zuiden van Europa al ingeburgerde maiswortelkever, Diabrotica sp. Deze soorten kunnen veel schade veroorzaken (tot $30 \%$ opbrengstreductie) wanneer ze niet goed bestreden worden. Ze rukken ook op naar het Noorden en incidentele noordelijke uitbraken worden voor alsnog uitgeroeid om dit zoveel mogelijk te vertragen. Desondanks was de Europese maïsstengelboorder in 2009 al doorgedrongen tot Normandië in Frankrijk en Zuidwest Duitsland en wordt sinds 2012 ook in Zuid Limburg gevonden (mondelinge informatie Jos Groten).

Ook onkruiden vragen meer aandacht in het zuiden. Daar waar bij ons slechts op een klein deel van het areaal meerdere keren per seizoen met onkruidbestrijdingsmiddelen wordt gespoten, is 
meermaals spuiten heel gangbaar in zuidelijkere streken. Verder zijn er naast de ook bij ons voorkomende onkruidsoorten, een aantal onkruidsoorten die in het zuiden belangrijk zijn en veel overlast geven. De soorten Sorghum halapense (wilde sorgo) en Datura sp. (doornappel) zijn hier nog niet erg gebruikelijk maar zijn daar belangrijke onkruiden.

Recent wordt er ook teosinte in Spanje en zuid Frankrijk gevonden (EFSA,2016). Het betreft hier een aantal soorten die familie zijn van de maïs en inheems in centraal Amerika, maar waarvan het zaad eerder uitvalt en die zich als onkruiden gedragen (vergelijkbaar met wilde haver in graanteelten) en zelfs ook een meerjarige soort.

\section{Gras}

Gewasbescherming in permanent grasland is bij een goed grasland beheer in Nederland niet nodig en ook niet gebruikelijk. Bij meer groeizaam weer voor het gras, wordt het makkelijker om door goed maaien breedbladige onkruiden te onderdrukken. Bij langere droge perioden is het wel belangrijk dat er niet intensief beweidt danwel tekort gemaaid wordt. Kale plekken in het grasland kunnen een poort voor veronkruiding zijn. De hogere temperaturen in de herfst en de winter zullen er toe leiden dat het gras langer doorgroeit. Tegelijk zal het ook natter worden in deze periode, zodat de bodem minder goed te berijden is om nog te kunnen maaien. Het gras gaat dan te lang de winter in, met als gevolg dat schimmelziekten meer zullen optreden (o.a. Fusarium).

Vickers (2009) verwacht dat de volgende problemen in Engeland in grasland zullen toenemen t.g.v. klimaatverandering: éénjarig straatgras (Poa annua), stengelaaltjes (Ditylenchus dipsaci), langpootmug (Tipula oleraceae), kroonroest (Pucinnia coronata), Drechsela en Rhynchosporium bladvlekken.

Een eventueel verhoogd voorkomen van de schimmelziekte Pithomyces chartarum bij natte een natte warme herfst, verdient aandacht. Deze schimmel die zich op dood gras ontwikkeld, veroorzaakt herfstzonnebrand of buitenblaar bij koeien. Met een goed grasland beheer (niet te kort grazen, omweiden, afwisselen met maaien en bijvoeren) zijn de problemen waarschijnlijk te voorkomen (communicatie JanRinze van der Schoot).

\section{Andere bekende en nieuwe voedergewassen}

Voor de voederproductie zijn diverse granen, vlinderbloemigen (erwten, bonen, luzerne), kruisbloemigen (kool- en raapzaden) en mogelijk ook voederbieten belangrijk. Aanvullend op de wat meer algemenere informatie over de gewasbescherming in paragraaf 2.2, worden hier nog een aantal specifieke aandachtpunten gemeld.

West (2012) verwacht ook meer problemen met Fusarium en mycotoxinen en een eerdere start van de bladvlekkenziekten in granen. Verder worden de problemen naar verwachting groter met de phoma stengelrot in koolzaad en kan de schade t.g.v. Sclerotina sclerotiorum stengelrot in diverse gewassen toenemen. Launay (2014) verwacht een eerdere start van de bruine roest in tarwe en netvlekkenziekte in gerst.

Het is de verwachting dat een aantal hier nog niet veel geteelde gewassen naar het Noorden steeds meer kansen krijgen (sojabonen, Sorghum en parelgierst, zonnebloem) (Eyshi Rezaei, 2015; West 2012). Zowel voor mitigerende reden (Jensen, 2012; Del Prado, 2015; Reckling, 2016) als ook t.b.v. het verminderen van de afhankelijkheid, prijsfluctuaties en import van sojabonen is het wenselijk dat we hier meer vlinderbloemige gewassen telen. Relatief nieuwe teelten vragen extra aandacht voor de gewasbescherming omdat veelal er nog weinig bestrijdingsmiddelen zijn toegelaten en omdat men nog ervaring met de gewasbescherming moet opdoen. Daarnaast kunnen onverwachte problemen optreden bij de introductie van het gewas in een meer Hollands bouwplan. Sclerotinia stengelrot is een ziekte die men in dat licht goed in de gaten moet houden (West, 2012). Ook met de nematodenbeheersing zouden onverwachte effecten kunnen optreden. 
Ook nieuwe biobased teelten op reststromen kunnen een heel wenselijke aanvulling zijn voor de productie van eiwitten, oliën en hoogwaardige inhoudsstoffen (van der Weide, 2014 en 2016; Spruijt, 2014). Reststromen zoals deze bij de vergisting van mest beschikbaar zijn, kunnen ingezet worden voor de productie van algen, eendenkroos en andere waterplanten. Hierbij wordt per oppervlakte eenheid tot 4-5 x zoveel eiwit geproduceerd. Bovendien bevatten sommige algensoorten waardevolle omega 3 en 6 vetzuren. Vervanging van een deel van het eiwit in het voer door algen, kan bovendien ook positieve effecten voor de gezondheid opleveren. De teelten moeten echter nog verder geoptimaliseerd worden en de gewasbescherming moet nog grotendeels ontwikkeld worden. 


\title{
Bijlage 3 Verslag kennissessie mitigatieperspectieven melkveehouderij
}

\author{
NB: Het onderstaande verslag geeft visies van deelnemers aan de workshop weer, en niet \\ van Wageningen UR.
}

\author{
Datum: 24 mei 2017 \\ Locatie: Wageningen \\ Verslag: Maarten Vrolijk en Marion de Vries (Wageningen Livestock Research)
}

Op 24 mei 2017 vond in het kader van het project Routekaart Klimaatslimme Melkveehouderij in Hotel De Wageningse Berg te Wageningen een kennissessie plaats over mitigatieperspectieven in de melkveehouderij. Het doel van de workshop was stakeholders te informeren over tussentijdse resultaten van het project, en een praktijkbijdrage te verkrijgen voor:

- De ontwikkeling van een visie voor de melkveehouderijsector over het vraagstuk van klimaatverandering (welke vraagstukken zijn belangrijk, hoe melkveehouders te betrekken, andere belangrijke partners);

- Prioritering en fasering voor onderzoek en praktijk, inclusief het toetsen van de haalbaarheid van mitigatie en adaptatie maatregelen voortkomend uit de factsheets;

- Actoren mobiliseren: vergroten van het perspectief dat de projecten en maatregelen die vanuit de routekaart worden ingezet ook gecontinueerd worden.

\section{Kennismaking}

Opmerkingen deelnemers tijdens kennismaking:

- $\quad$ Boeren zijn niet bezig met CO2 - waan van de huidige dag wordt bepaald door fosfaat etc.

- $\quad$ Behoefte aan tool voor individuele melkveehouders om te bepalen waar ze nu staan.

- $\quad$ NZO heeft een taskforce CO2.

- $\quad$ LTO: Landbouwsector kan een speelbal gaan worden in politieke belangen, om CO2 emissies terug te dringen. Als multinationals bepaalde tools 'opdringen' dan moeten die wel aansluiten op wat de NL melkveehouderij gebruikt.

- $\quad$ Onderwerp is complex voor boeren, vrijwel niemand snapt het (rol voor erfbetreders).

2. Presentatie Jan Peter Lesschen (Alterra WUR): 'Voorstel Effort Sharing Regulation en emissiereductie in de melkveehouderij'

- Meeste broeikasgasemissies (BKG) uit de landbouw afkomstig van i) fossiele brandstoffen (m.n. glastuinbouw), ii) pens fermentatie (m.n. rundvee), iii) landgebruik (m.n. organische bodems), iv) N2O bodem emissie (veengrond emissies), v) mestopslag. (data gebaseerd op lange meetreeksen);

- Vastlegging van CO2 bij veranderd landgebruik wordt ook meegeteld (negatieve emissies). Belangrijkste levering van organische stof zijn stoppel en wortel, en door niet te ploegen; minder aanvulling via organische mest. Vooral lachgas emissie is afgenomen in de afgelopen decennia. (bron emissieregistratie, PBL).

- Parijs akkoord: temperatuursverandering onder 2 graden, tweede helft $21^{\mathrm{e}}$ eeuw: netto nul emissies (akkoord getekend in april 2016).

- Het relatieve aandeel van BKG uit de landbouw zal groeien richting 2050, vanwege afname van BGK in internationale scheep- en luchtvaart en overige sectoren.

- Doelstelling EU is 40\% reductie BKG in 2030 t.o.v. 1990. Voor ETS sectoren betekent dit een reductie van 43\% (t.o.v. 2005). Voor non-ETS sectoren (waaronder landbouw) in hele EU $30 \%$ t.o.v. 2005. Nu in onderhandeling.

- $\quad$ Voor Nederland betekent deze Effort Sharing Regulation (ESR; gebaseerd op BNP per EU lidstaat) een reductiedoelstelling van 36\% (123 Mton CO2e) in 2030 t.o.v. 2005. Nederland mag dit zelf verdelen over sectoren.

- $\quad \mathrm{Er}$ is enige flexibiliteit in ESR: 
- Deel van de emissierechten kan worden afgekocht door meer in de ETS te doen (max. $2 \%$ van 2005 emissies).

- Veranderingen in landgebruik (LULUCF) tellen nu nog niet mee, maar mogen worden ingezet om 2030 doel te realiseren $(\max 1.1 \%=13.4$ Mton $\mathrm{CO} 2$ uitruil over periode 2021-2030)

- Bodem en bossen zit in LULUCF (CO2). In oud bos is al een evenwicht: geen netto winst.

- $\quad$ EU voorstel LULUCF om managed grassland and cropland te verplichten voor accounting (t.o.v. 2005-2007, max. 1.1\%). Credits kunnen pas worden ingezet als je netto geen (positieve) emissies hebt in LULUCF, en kan je uitwisselen tussen landen. Een vraag is of deze $1.1 \%$ naar de landbouw kan worden toegehaald.

- $\quad$ Niet één maatregel maar een mix van maatregelen is het meest effectief om bodemkoolstofopslag te verbeteren. Bodem koolstof kan worden beïnvloed via:

- Minder grondbewerking (niet-kerende grondbewerking, niet scheuren grasland)

- Meer gewasresten (vanggewas, groenbemester, permanent gewas in rotatie, gewasresten achterlaten)

- Toevoegen extra organische stof via meststoffen (dierlijke mest, compost, overige org. meststoffen)

- Aanplant meerjarige gewassen of houtopstand

- Verhogen waterpeil in veengronden (onderwaterdrainage, omzetting naar natuur)

- De maximaal haalbare koolstofvastlegging in minerale bodems in de Nederlandse landbouw is ongeveer 1 Mton CO2 per jaar (5,5\% van de huidige emissies uit de landbouw sector)

Discussie:

- $\quad$ Lesschen en Vellinga benadrukken niet te hoge verwachtingen te hebben over koolstofvastlegging in grasland. Bepaalde bodems bereiken hun evenwicht al op 2-3\% (oud grasland). Het grootste deel van het grasland in Nederland is al oud grasland.

3. Presentatie Theun Vellinga (Wageningen Livestock Research): 'Voorstel Effort Sharing Regulation en emissiereductie in de melkveehouderij'

- $\quad$ Mitigatie is nu vooral ingezet op efficiëntie verhogen. Een sterk geoptimaliseerd systeem met zeer hoge producties per dier is kwetsbaar voor toename in weersextremen en de bijbehorende gevolgen;

- Gemiddelde emissie intensiteit Nederlandse melkveehouderij is nu $1240 \mathrm{gram} \mathrm{CO2e/kg} \mathrm{melk.}$ In 2030 zou $-36 \%$ een emissie intensiteit van 800 gram/ kg melk betekenen, bij gelijkblijvend melkvolume;

- Mitigatie maatregelen:

- Emissies op bedrijf door fossiele brandstoffen (diesel, energie) vergroenen

- Emissies in de (voer)keten vergroenen (veevoerleveranciers)

- Biologische processen beinvloeden (voeradditieven, nitrificatieremmers, vergisting)

- Efficiëntie verbeteren (melk per koe, minder jongvee/koe, verliezen, voerefficiëntie)

- Andere bedrijfsvoering: rantsoen, landgebruik, klaver (i.p.v. kunstmest), weidegang (kan emissies verminderen indien op juiste manier)

- $\quad$ Een theoretische verkenning is uitgevoerd om te bekijken hoe ver CO2e per kg melk kunnen worden verlaagd. Daarbij is niet gekeken naar andere doelen als weidegang, gras/maïs verhouding, etc. (data uit KringloopWijzer)

- Meeste emissies: CH4 pens, CO2 aangekocht voer, CH4 mest (CO2 emissies aangekocht voer en kunstmestproductie vallen echter buiten het melkveebedrijf);

- Emissies verminderen:

○ Pens: pensfermentatie remmen (15\%, bijv. 3NOP), fokkerij $(-15 \%)$;

- Mestopslag: vergisting (70\%)

- Bodem: klaver introduceren grasland (50\%) (zowel t.b.v. lachgas emissies als adaptatie)

- Energie: vergroenen bedrijf (100\%, diesel en elektriciteit) en voerketen ( $30 \%)$

- Kunstmest: verminderen en lage CFP (50\%)

- Sturen met rantsoen:

- Krachtvoer vervangen door enkelvoudige krachtvoeders

- Gras vervangen door mais, tenzij het een trade-off met scheuren van grasland betreft.

- In project Vruchtbare Kringloop Achterhoek (VKA) realiseren boeren gemiddeld 1086 gram $\mathrm{CO} 2 \mathrm{e} / \mathrm{kg}$ melk, en voornemen is om onder $1000 \mathrm{~g}$ te realiseren ( $200 \mathrm{~g}$ lager dan gemiddeld $\mathrm{NL}$ );

- Belang van investeren in bodemkwaliteit 
- $\quad$ Bij huidige sturen op efficiëntie is reflectie nodig: willen we zo'n gevoelig systeem? Win-win situaties kunnen komen uit investeren in bodemkwaliteit, verkenning rol van klaver en remmen methaan uit mest, en integraties met andere functies om weerbaarheid te verhogen (bijv. waterberging, natuur).

Discussie

- $\quad$ Idee om BKG per ha uit te drukken i.p.v. per kg melk, vanwege grondgebondenheid, meer extensieve melkveehouderij (TV: Nee, BKG is een globaal effect)

- $\quad$ Aanpassen van rantsoenen t.b.v. mitigatie kan een uitwerking hebben op de gezondheid van koeien, bijv. mogelijk minder oude koeien en meer jongvee nodig. Wordt dit meegerekend? (TV: Nee. Dit kan in een pilot worden meegenomen in berekeningen.)

- Waarom niet meer drijfmest gebruiken en minder kunstmest aanvoeren op het bedrijf (daarmee ook stimulans mestverwerking). (TV: Wordt aan gerekend om te kijken wat dat met carbon footprint doet)

- Processtappen naar de melkveehouders toe: hoe ga je de maatregelen laten landen op het erf? Dat is een zorg van de vakgroep en andere actoren en gaat niet vanzelf. Bewustwording vergroten, inzicht in mogelijke maatregelen en kosten en effect van die maatregelen en hoe gemakkelijk of complex om die maatregelen te realiseren.

- Veengrond vernatten is een kostbare maatregel. Gaat dat niet ten koste van de veenweidegronden? Hoe groot is je potentie om emissies uit veenweide te verminderen? Vernatten, wat kost dat? Is het dat waard? (Zegveld onderzoek is erg waardevol: peilverhoging, toch mogelijkheid voor agrarische activiteiten)

- $\quad$ Nog veel vraagtekens en veel onbekend onder melkveehouders. Zij hebben allereerst een tool nodig om te weten waar ze staan. Je kunt ondernemers informeren, maar ze gaan niks doen als ze niet weten wat de huidige situatie is, wat de verbeterpotentie is en via welke maatregelen die te realiseren is. Ook goed kijken naar integraliteit. (Tool wordt ontwikkeld, gekoppeld aan kringloopwijzer)

\section{Plenaire terugkoppeling en discussie}

- Benchmarking is nodig in de praktijk / maatregelen naast elkaar testen op pilot bedrijven: wat betekent dat voor bedrijfsvoering (haalbaarheid), welke relatie is er met bodem, en welke kennishiaten moet je dan tackelen?

- $\quad$ Teveel focus op koeien in de praktijk en te weinig op de bodem. Dat moet veranderen willen we voldoende klimaat slimme melkveehouderij realiseren. Winst van een bedrijf begint in de bodem, en de bodem is een productiemiddel met een langere productietijd dan een individuele koe. Echter wordt je v.w.b. mitigatie afgerekend op de koe en niet op de bodem;

- $\quad$ Actuele meetreeksen zijn gewenst: aannames worden nu teveel gebaseerd op oude data meetreeksen.

- Overheid is niet aanwezig op bijeenkomst: welke rol kan zij vervullen? Overleggen wensen sector m.b.t. plannen $\mathrm{CO} 2$ reductie sector, bijv. met subsidies of wetgeving.

- $\quad$ 'Reductie van de veestapel' kan een vraag worden vanuit overheid - hierop moet je concreet antwoord kunnen geven. Wat betekent dat voor de sector, en wat betekent het voor de economie?

- Topsectoren: geld vrij maken om onderzoek te doen aan bodem (PPS-en)

- Van belang om dezelfde taal te spreken. Vooral de overheid communiceert op een heel ander niveau dan ondernemers. Vertaling is nodig.

- Onderzoek: Zijn er dingen die de sector nu al doet, die niet in beeld zijn maar wel meetellen?

- Voorzichtigheid is geboden met het communiceren van mitigatiemaatregelen, daar schuilt een gevaar in dat de sector/ bestuurders dit aannemen als het ei van Columbus.

- $\quad$ Goed voorbeeld voor aanpak is het mineralen project Praktijkcijfers, om een breder beeld te krijgen met huidige praktijkcijfers en potentie voor reductie.

- Voor de Routekaart is van belang:

Lijst maatregelen, kosten (bedrijfsniveau) en mitigatie effect.

Bodem komt op langere termijn.

Bedrijfsspecifiek inzichtelijk krijgen waar boeren voor beloond worden. Bijv. weerbaarheid van de koe op orde, dat belonen (zuivel/overheid). Maatregelen lijstje wel kunnen aantonen (GLB, moet wel kloppen!)

Nabranders

- Educatie heel belangrijk, niet eenmalig. Bewustzijn vergroten komende tijd, aan blijven werken.

- $\quad$ Maatregelen testen in pilots: wat gaat er gebeuren, zijn er afwentelingen? Niet op proefbedrijven maar op praktijkbedrijven testen. 
- Wat zijn no-regret maatregelen?

- Gemakkelijk: zonnepanelen, wind, groene stroom, fokkerij, vergroening in de keten, kunstmest met lage footprint.

- Moeilijker: melkproductie verhogen.

- Lastiger: klaver behouden. 


\section{Bijlage 4 Verslag workshop klimaatbestendige melkveehouderij}

\section{NB: Het onderstaande verslag geeft visies van deelnemers aan de workshop weer, en niet van Wageningen UR.}

Datum: 25 april 2017

Locatie: Beers

Verslag: Luuk Gollenbeek en Maarten Vrolijk (Wageningen Livestock Research)

Op 25 april 2017 vond in het kader van het project Routekaart Klimaatslimme Melkveehouderij op Landgoed de Barendonk te Beers een workshop plaats over Klimaatbestendige Melkveehouderij. Tijdens deze workshop hebben stakeholders verschillende adaptatie thema's bediscussieerd. Het doel van de workshop was stakeholders te informeren over tussentijdse resultaten van het project, en een praktijkbijdrage te verkrijgen voor:

- De ontwikkeling van een visie voor de melkveehouderijsector over het vraagstuk van klimaatverandering (welke vraagstukken zijn belangrijk, hoe melkveehouders te betrekken, andere belangrijke partners);

- Prioritering en fasering voor onderzoek en praktijk, inclusief het toetsen van de haalbaarheid van mitigatie en adaptatie maatregelen voortkomend uit de factsheets;

- Actoren mobiliseren: vergroten van het perspectief dat de projecten en maatregelen die vanuit de routekaart worden ingezet ook gecontinueerd worden. De stakeholders hebben aangegeven bij welke onderdelen van de routekaart ze betrokken willen worden zodra die nader uitgewerkt worden.

\section{Presentaties: Wat is klimaatslimme melkveehouderij?}

Door: Maarten Vrolijk, Idse Hoving, Jantine van Middelkoop, Jan ten Napel (WLR)

Korte toelichting over mogelijke effecten van klimaatverandering op de productie van gras en voedergewas, waterbeheer, en dierziekten in de melkveehouderij, en mogelijke oplossingsrichtingen. Deze toelichting is gebaseerd op factsheets gemaakt door onderzoekers van Wageningen University \& Research over deze thema's, o.b.v. van KNMI klimaatscenario's.

\section{Groepsdiscussies per thema}

Met inbreng van deelnemers werd duidelijker wat nodig is om de Nederlandse melkveehouderij klimaatbestendiger te maken. Wat kan de sector nu al doen, welke kennis- en onderzoeksvragen zijn er voor oplossingen op de langere termijn, welke rol kunnen deelnemende organisaties daarin vervullen, en andere vragen.

Discussiegroep Water

Subthema's (uit presentatie WLR): waterbeheer $21^{\mathrm{e}}$ eeuw, agrarisch stuwpeilbeheer, peilgestuurde drainage, gewaskeuze, bodemstructuur, beregening en waterberging.

\section{Waterbeheer $21^{\mathrm{e}}$ eeuw:}

- $\quad$ Per gebied moet de wateropgave samen worden ingevuld met agrarische partijen, ook moet worden gedacht aan de drooglegging van deelgebieden;

- Ruimte voor water moet worden gecombineerd met ruimte voor landbouw in de deelgebieden;

- $\quad$ Er moet flexibiliteit in peilbeheer komen om te anticiperen op verschillen in plaats en tijd;

- Is er meer lokale verantwoordelijkheid in waterbeheer mogelijk? Hoe is te organiseren?;

- Natuurvriendelijke oevers moeten verder worden doorgevoerd;

- 'Groen/blauwe diensten leidt tot versnippering van agrarische gebieden'. Wat zijn de mogelijkheden van aankoop van gronden?;

- Wat zijn mogelijkheden voor water als klimaatdienst? 
- Hoe toename waterbuffering beheersbaar maken voor melkveehouders? (aanvulling uit plenaire bespreking)

Provinciaal omgevingsplan

- Grensoverschrijdende waterbeheerplannen i.p.v. een plan per waterschapgebied is mogelijk gewenst?

- Wat betekent dit voor natuurvriendelijke oevers, technische maatregelen, drooglegging en waterkwaliteit?

- Planvorming wateropgave (PWO) is per gebied. Meer aandacht voor relevante onderdelen van deze opgaves i.r.t. klimaatslim. Denk aan omschrijving van het probleem, vergroten van draagvlak bij actoren in het gebied voor de maatregelen, proces van vaststellen van het plan en de uitvoeringsfase.

Agrarisch bedrijf

- Wat ondernemers zelf kunnen doen: realiseren van minder afspoeling van percelen en erf, meer waterberging op perceel;

- Hogere prioriteit geven aan verbeteren van de bodemstructuur en organische stof (waterbuffering);

- Gezonde bodem is de basis; (aanvulling uit plenaire bespreking)

- Vergroten van de kennis over waterbehoefte van het bedrijf en van watermanagement, zeker als de aanvoermogelijkheid van water beperkt is;

- Verzekeren tegen risico op waterschade;

- Ander bedrijfssysteem overwegen en realiseren: extensiever met meerwaarde, gemengd bedrijf (is robuuster), alternatieve teelten (die langdurige droogte of inundatie overleven), voorraad ruwvoer voor langere periode beschikbaar hebben;

- Waterkwaliteit versus kwantiteit: water is niet alleen maar water maar bevat ook andere stoffen, zowel van belang voor planten als voor dieren (aanvulling uit plenaire bespreking)

Beregening

- Beregenen zou je niet moeten willen; (aanvulling uit plenaire bespreking)

- Lonend bij de teelt van kapitaal intensieve gewassen;

- Beperking van waterbeschikbaarheid bij langdurige droogte, hoe te organiseren?

Exit strategie

- Gebieden uitsluiten voor landbouw of voor bepaalde vormen van landbouw indien de watercondities kritische grenzen overschrijden

- Exit scenario vorm geven: bepaal de stappen die onderdeel zijn van zo'n scenario. Wat is bekend en wat moet verder uitgewerkt worden? (aanvulling uit plenaire bespreking)

Systeem nodig dat verder gaat dan optimaliseren

- Vruchtwisseling

- Akkerbouw/veehouderij

- Gras is gunstig gewas voor bodemstructuur en vruchtbaarheid

Faciliteren in instrumenten/tools die watersituatie inzichtelijk maken

- Bijvoorbeeld de Bedrijfswaterwijzer;

- Daar waar zich problemen voordoen, mogelijkheid hebben om via maatwerk wel tot oplossingen te komen.

Aanvullingen tijdens plenaire bespreking

- Scenario denken: welke doelen wil je halen / wat wil je wel/niet met de sector?

- Maak meer gebruik van de gebiedskennis die boeren hebben, hydrologische modellen hebben niet altijd gelijk.

- Bij waterbeheer meer en eerder economische afwegingen van maatregelen maken.

Discussiegroep Gras en Gewas

Subthema's (uit presentatie WLR): Meer grassoorten vlinderbloemigen, Alternatieve voeder gewassen telen, Flexibele beweiding / voer budgettering, Bodemwater beheer, Mestopslag en toediening verder verbeteren 
- Volgens deelnemers wordt al aan bovenstaande subthema's gewerkt, zorg voor verdergaande kennisontwikkeling;

- $\quad$ Andere belangrijke thema's zijn bijvoorbeeld mestkwaliteit i.r.t. bodemkwaliteit (bijv. vaste mest), en mestvergisting versus bodemleven (kwaliteit van vaste mest en digestaat is een kennisvraag;

Mest

- Mest is de belangrijkste factor bij herontwerpen. Mest is bepalend voor de gehele ontwikkeling van de bedrijfstak. Hoe sluit je aan met mest op de akkerbouwbehoefte?

- Oude systeem van grupstal met gescheiden mest en urine versus mengmest waarbij bodemleven lager, graskwaliteit lager, krachtvoerverbruik hoger, C kwijt, extra NH4 -> kan type mest van grupstal terugkomen?

- $\quad$ Stikstof kunstmest grotendeels vervangen door mineralen concentraat o.b.v. mestscheiding. (aanvulling uit plenaire bespreking)

- Met biogas vergisting haal je $C$ uit het systeem, op digestaat zitten we niet te wachten.

- Een zo hoog mogelijk OS-gehalte is niet nodig, streef naar een optimum per grondsoort/perceel;

- $\quad$ Let op dat bemesting aangepast wordt op veranderingen. Bemestingsbeleid is nu leidend.

- Structureel klimaatslim mestbeleid is nodig, moet een stabiel speelveld voor de lange termijn bieden. Neem maatschappelijk draagvlak en druk daarin mee.

Mineralen

- Het is belangrijk rekening te houden met mineralenstromen in de regio, dus regionale kringlopen. Vraag daarbij is hoe groot is een regio is;

- Op gebiedsniveau concentreren van activiteiten waar het past, climate smart landscaping

- Sectoren aanpassen om regionale kringlopen te sluiten, daardoor (mogelijke) verandering van structuur van sectoren;

- Meer eiwit voor veevoer door akkerbouwbedrijven. Vraag daarbij is welk gewas je gaat vervangen?;

Andere aanpassingsmogelijkheden onder klimaatverandering

- Genetische modificatie (GMO) inzetten om gewassen sneller aan te passen aan andere groeiomstandigheden?

- Kijk uit voor trade-offs, blijf met integrale blik de maatregelen beoordelen op geschiktheid;

- Wintergewassen telen biedt mogelijkheden, bijv. winterveldbonen of -erwten. Kan voor eiwit en energiedoelen.

- Begin bij de markt: meer specials produceren en bulkproductie loslaten - wat betekent dit voor teeltsysteem en kostprijs?

- 'Gezonde' rantsoenen: kruiden bijv eventueel andere vruchtwisseling daarbij nodig

- We gaan naar 'stadslandbouw' (in brede betekenis)

- $\quad$ Scenario denken, en kringloop denken - ook voor C.

- Verzekeren;

Relatie mitigatie

- Ga uit van doel: in 2050 emissies zo laag mogelijk

- Klimaatbeleid voor landbouw: adaptatie en mitigatie, integraal naar milieu effecten kijken. Sector kan ook positief bijdragen. Welke omvang van zuivel productie is in NL mogelijk. Methaan kan niet naar 0. (aanvulling uit plenaire bespreking)

Herontwerpen

- Hoe ziet de landbouw eruit in 2050: de tekortkomingen van het huidige systeem oplossen door middel van herontwerp van het hele systeem.

- Ontwerpen? Ja, maar dan vooral ook op gebiedsniveau; (aanvulling uit plenaire bespreking)

- Herontwerpen voor ruimte in het systeem of voor beheersing van het systeem? (aanvulling uit plenaire bespreking)

- Systeemdenken: wat is nodig: robuuster en flexibeler systeem, krachtvoer en kunstmestgebruik en productie zulle lager zijn dan in huidig systeem. Nadenken over welk bedrijfssysteem, welk stalsysteem, welke koeien, etc.

- Denk niet alleen aan meer intensief maar aan hoe je beter kunt gebruiken wat er al is: de kracht van de bodem, koe en gras.

- Durf te denken aan lager productieve koeien, duurzaam extensiveren. Via minder productie per koe of lagere totale productie? 
- Waar willen we vanaf? Afhankelijkheid voerimport, kunstmest, beregenen..... Dan moet je de hoe vragen gaan beantwoorden -> vraagt om Ontwerpen

- Onderzoek vragen met vergaande consequenties, bijv. 'Veen niet meer gebruiken voor landbouw?' Wat zijn dan die consequenties, en via welke maatregelen is dit te voorkomen of zo goed mogelijk te realiseren?

- Welke keuze je maakt voor gebied: voor klimaat slimme (klimaat neutrale) landbouw is compensatie buiten melkveehouderij nodig.

Aanvulling tijdens plenaire discussie

- Organische stof, dierlijk, menselijk, natuur, als basis voor toekomstige ontwikkeling van landbouw.

- Gewasbescherming en mest, bodem en emissies meenemen in systeemverandering.

\section{Discussiegroep Diergezondheid}

Subthema's (uit presentatie WLR): Beheersmodel $=$ bron gericht, Adaptatiemodel $=$ impact gericht

Infectieuze aandoeningen

- Bij de hoofdgroepen vectoren, parasieten en bacteriën is een groep toegevoegd, namelijk het ontstaan van nieuwe ziekten door vermenging DNA. Vectoren zijn de grootste bron van zorg volgens de groep.

Niet infectieuze aandoeningen

Mind map

- Hoofdgroepen zijn hitte stress, metabole stress, uitdroging en vergiftiging.

- Deelnemers hebben discussie in beeld gebracht met behulp van een mind map (zie foto's).

- Bij veel van de oplossingen zijn ook conflicterende zaken bijvoorbeeld biodiversiteit (robuuster systeem) versus kaalslag (geen biotoop voor parasieten en gastheren).

- Beter inzicht in de gevolgen krijgen wat het effect is op welzijn en weerstand. Bekende onbekende, voorspellend zijn is erg belangrijk. Hoe hou je dit in de gaten. Europa, handelsbewegingen en dergelijke. Kwetsbaarheid neemt op bedrijfsniveau toe.

- Hoe zorg je ervoor dat symptomen worden herkend? Monitoren en signaleren is dus erg belangrijk.

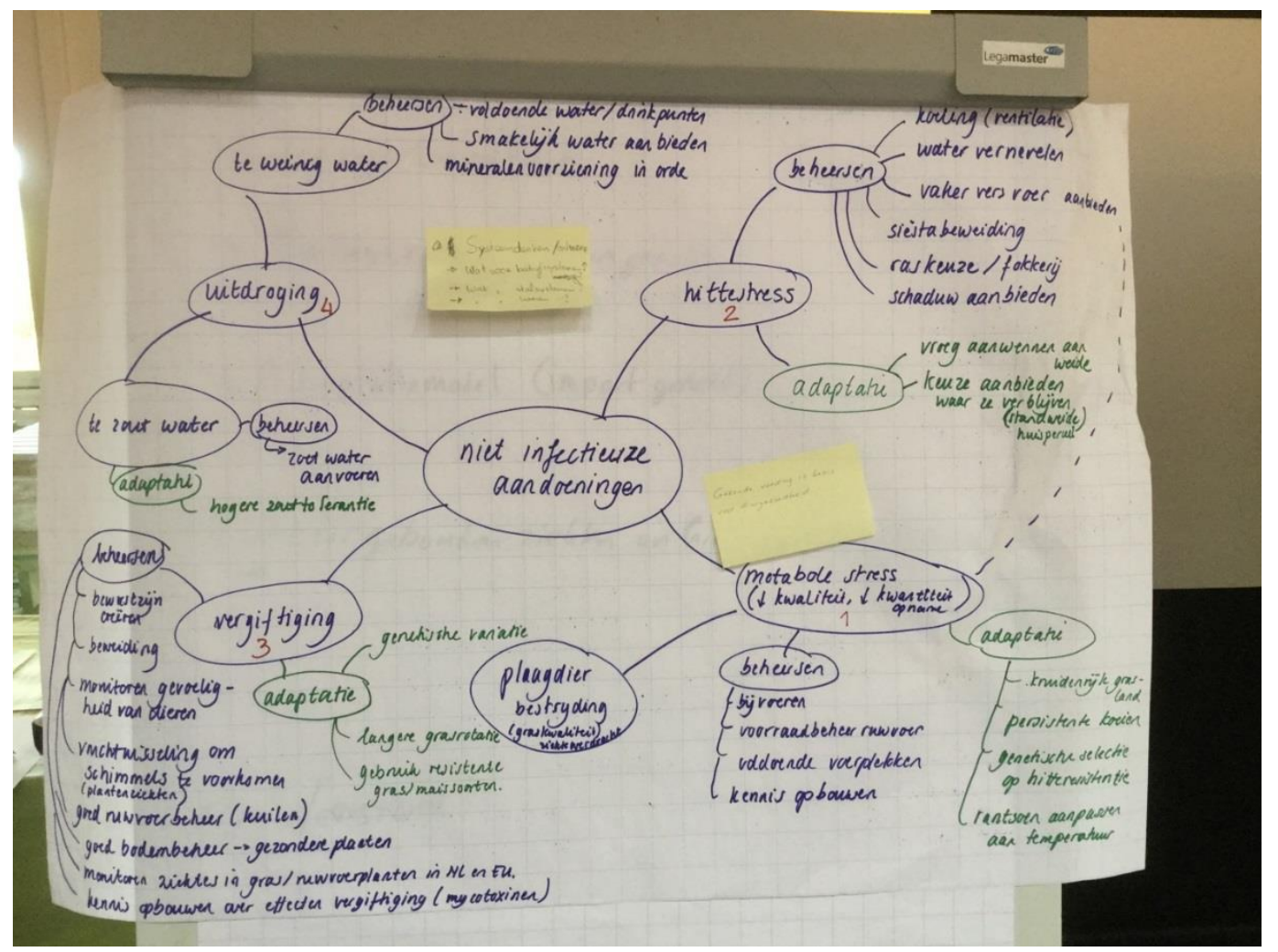




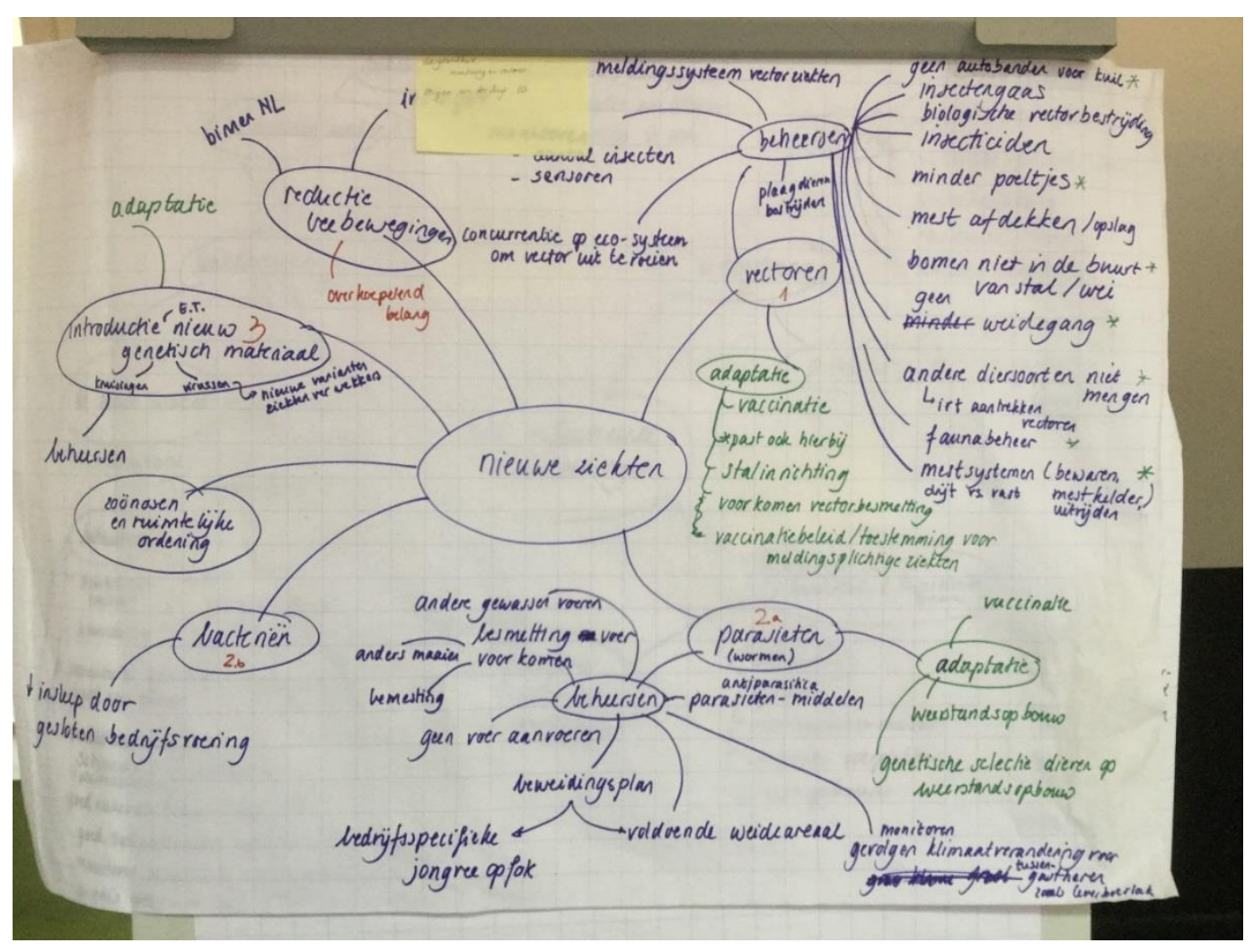

\section{Plenaire terugkoppeling en discussie}

In de discussie is vooral ingegaan op beleid en planvorming, bodem en gewas. Er is een indeling gemaakt in:

- Planvorming: op gebiedsniveau en regionaal (waterbeheer peilbeheer) aanpassen. Hier is draagvlak voor nodig en er zal een spanningsveld zijn met andere gebruikers. Aanvulling hierop is dat aanpassingen zullen stuiten op weerstand, dus je kunt hier niet als eenling aan beginnen, ook de buren moeten meedoen.

- Landbouwers: BOOT lijst geeft mogelijkheden om als landbouwer maatregelen ten nemen. Het krijgen van een goed inzicht in waterbeheer op het bedrijf en in de regio is de eerste stap. Samenwerking is belangrijk binnen een stroomgebied of een peilgebied. De bedrijfswaterwijzer zou moeten aansluiten op gebiedsniveau om zodoende maatregelen binnen een stroomgebied of peilgebied te kunnen bepalen. De maatregelen zitten vooral in de optimalisatie van de bestaande situatie, er zijn echter ook alternatieven mogelijk.

- Alternatieven: Veranderende omstandigheden leiden mogelijk tot alternatieven als: stoppen of andere gewasteelten. Voorbeeld peilverlaging niet mogelijk dus ga eens kijken naar alternatieve gewassen. Calamiteiten let op verzekeringsmogelijkheden, bedrijfsbeëindiging ligt op de loer. Bij aanhoudende droogte geldt vaak ook een beperking voor beregening, dus bedrijfsvoering aanpassen in plaats van naar beregening te grijpen heeft de voorkeur. Mogelijk zijn gemengde systemen in samenwerking met akkerbouwer robuuster. 


\section{Bijlage 5 Aanbevelingen voor onderzoek per discipline}

Thema

Adaptatie

limatp

Klimaatscenario's doorrekenen o.b.v. locatie en bedrijfskenmerken: Op basis van BBPR berekeningen en bodemhydrologische- en bedrijfskenmerken kunnen effecten van klimaatscenario's worden doorgerekend voor diverse locaties en bedrijfstypen. Hiermee kunnen klimaatrisico's en adaptatiemogelijkheden (incl. kosteneffectiviteit) voor verschillende bedrijfstypes en gebieden in beeld worden gebracht.

2. Effecten van klimaatverandering op bedrijfsresultaat en emissie intensiteit (i.c.m. voorgaand onderzoek): In het huidige rapport is beschreven op welke manier klimaatverandering en (een gebrek aan) klimaatadaptatie invloed kunnen hebben op de emissie intensiteit. Aan de ene kant is er de verwachting dat hogere temperaturen en $\mathrm{CO} 2$ concentraties bijdragen aan hogere gewasopbrengsten. Aan de andere kant zullen weersextremen negatieve gevolgen hebben voor de bedrijfsvoering en productiviteit. De kennis over hoe klimaatscenario's kunnen uitwerken op bedrijfsniveau is tot dusver echter zeer beperkt (o.a. Paas et al., 2016). Dit komt o.a. door i) de onzekerheden in scenario's voor klimaatverandering en effecten op de melkveehouderij, ii) invloeden van andere (bijv. sociaaleconomische) ontwikkelingen die hier doorheen spelen, en iii) de complexiteit van relaties tussen effecten van klimaatverandering en de uitstoot van emissies, en de manier waarop mitigatie- en adaptatiemaatregelen deze relaties beïnvloeden. Kennis over klimaatrisico's en -kansen voor de melkveehouderij en de relatie tot bedrijfsresultaat en milieupresentaties helpen de sector te anticiperen op een onzekere toekomst. Een mogelijke uitkomst is dat adaptatiemaatregelen onderdeel worden van de mitigatiestrategie.

Mitigatie 1. Mitigatiepotentieel op sectorniveau. Emissiereductiegetallen vermeld in deze studie konden niet worden gebruikt om een mitigatiepotentieel op sectorniveau te berekenen omdat resultaten case studies betroffen, waardoor behaalde emissiereducties niet per definitie representatief zijn voor het gemiddelde Nederlandse melkveebedrijf. Ook is voor een inschatting op sectorniveau het nodig te weten hoeveel bedrijven de maatregel kunnen toepassen op het bedrijf (ontsluitingspercentage), en hoe effectief de maatregel is op verschillende typen bedrijven (bedrijfsspecifiek emissiepotentieel). Voor het samenstellen van een maatregelenpakket is tevens inzicht in overlap en interactie tussen maatregelen van belang; effecten kunnen niet zonder meer worden opgeteld. Voor sommige maatregelen is de wetenschappelijke onderbouwing voor inschatting van het mitigatie effect schaars, met name v.w.b. analyse op hogere systeemniveaus (bijv. keten of voedselsysteem).

2. Koolstofvastlegging. De mogelijkheden van koolstofvastlegging zijn gebaseerd op rekenmodellen, die weer op hun beurt zijn gebaseerd op lange tijdreeksen uit het verleden. Een systematische literatuuranalyse en een diepgaande analyse van gegevens over organische stofgehalten onder grasland is gewenst. Tot nu zijn de bodemgegevens geaggregeerd onderzocht. Het uiteenrafelen om goede tijdreeksen te vinden kan de mogelijkheid tot vastlegging onderbouwen. Dat heeft betrekking op landgebruik, maar ook op management.

3. Ontwikkelscenario's melkveehouderij. Doorrekenen van implicaties van verschillende ontwikkelscenario's voor emissieniveaus in de melkveehouderij, o.a. in relatie tot het advies Grondgebondenheid, circulaire landbouw, en natuurinclusieve landbouw. Een eerste stap is het verkennen en omschrijven van de verschillende scenario's, zoals de betekenis en mogelijkheden van circulaire landbouw. In een tweede stap worden mogelijkheden voor mitigatie onder verschillende scenario's verkend.

Systeem onderzoek (integrale duurzaamheid)
1. Perspectieven melkproductieverhoging. Gelinkt aan punt 2 van mitigatie lijkt het huidige spoor van optimalisatie van de melkproductie per koe voor- en nadelen te hebben. Zo leidt de verhoging van de melkproductie per koe en verlenging van de levensduur tot minder rundvlees, en kan deze eenzijdige optimalisatie leiden tot hogere emissies door het meer importeren van rundvlees (NL importeert nog steeds veel rundvlees) met hoge emissies zolang de rundvleesconsumptie niet sterk daalt (Vellinga en De Vries, 2018). Een verdere optimalisatie naar melkproductie leidt daarnaast tot verdere conditionering, wat gevolgen kan hebben voor de robuustheid van het productiesysteem. De klimaatverandering zal eisen stellen aan een hogere weerbaarheid van bedrijven. Specifiek onderzoek naar een breed palet van voor- en nadelen van melkproductieverhoging is wenselijk.

2. Pilots klimaatslim melkveebedrijf 2030: In pilots wordt op diverse locaties in Nederland op praktijkbedrijven gewerkt aan het ontwerpen van een integraal klimaatslim melkveebedrijf richting 2030. Hierbij worden adaptatie- en mitigatiemaatregelen gecombineerd. Pilots vinden plaats op locaties gevoelig voor specifieke klimaatrisico's en op diverse bedrijfstypes (bijv. intensiteit, bedrijfsomvang, grondsoort). Met stakeholders wordt bepaald waar kansen zijn voor waterberging, verzilting een rol speelt, waar melkveehouderij een belangrijke rol kan spelen voor de akkerbouw, of hoe vormen van veehouderij in toekomstige marginale gebieden eruit zien. Verdienmodellen worden doorgerekend op basis van vergoedingen voor alternatieve functies en emissies worden doorgerekend met methodes passend bij een hogere systeemniveau. 
1. Robuuste rassen kweken, gras, mais, andere voedergewassen voor GPS. Welke? Aan welke eigenschappen moeten deze gewassen voldoen?

2. Inpassen van vlinderbloemigen. Hoe? Wat is de invloed op mitigatie (voeding en enteric methaan) en $\mathrm{N}$-uitspoeling?

3. Introductie van alternatieve gewassen. Welke? Luzerne, soya, sorghum, sainfoin?

4. Introductie van multi-species grasland. Hoe gedraagt multi-species grasland zich in Nederland, wat zijn voederkwaliteiten en kunnen daar onze hoge (melk)producties mee gehaald worden?

5. Aanpassing van graslandmanagement. Hoe zou dat aan te passen zijn? Strookt dat met mitigatie, en met mineralenefficiëntie?

6. Verhogen van de veerkracht (resilience) op klimaatverandering van het grasland en overige voedergewassen. Hoe? Of hebben we meer resilience of flexibiliteit van het bedrijf nodig? Moeten we zoeken naar resilience van de bron (eigenschappen van grasrassen aanpassen of andere soorten gebruiken) of resilience op de impact van de bron (bedrijfssysteem aanpassen)?

7. De water kwantiteit op het veld is sterk bepalend voor de effecten van klimaatverandering. Bodemstructuur en een goede/veilige ontwatering zijn daarbij belangrijke randvoorwaarden. Is dat goed in Nederland of kan daar aan verbeterd worden? En hoe kan dat, zonder "kortsluiting" van perceelwater met slootwater en daardoor afspoeling van nutriënten te vergroten waardoor de oppervlaktewater kwaliteit in het geding komt?

8. Flexibeler beweiden, mogelijkheden om dieren binnen te houden als het weer het niet toelaat om te weiden. Welke uitdagingen komt de melkveehouderij tegen bij beweiding? Beweiding wordt nu steeds verder naar achteren geschoven ten behoeve van een volledige eerste snede maaien en daarmee de beschikbaarheid van hoge kwaliteit ruwvoer maar het vergroot het risico op NO3-uitspoeling.

9. De keuze in krachtvoeders/aangekocht voer zal aan moeten sluiten bij de behaalde kwaliteiten ruwvoeders. Welke kwaliteiten zijn nodig? In hoeverre helpen die bij het behalen van andere milieudoelen?

10. Mestwetgeving. Hoe verhouden mitigatie en adaptatie maatregelen zich met de huidige en toekomstige mestwetgeving? Bijvoorbeeld: de verwachting is dat de N-behoefte van grasland toeneemt door klimaatverandering, binnen de huidige mestwetgeving kan daar niet op ingespeeld worden.

11. $\mathrm{Er}$ is in Nederland op het moment veel aandacht voor uitruil tussen akkerbouw en melkveehouderij in verband met organische stof beheer. Op gebieds-/nationaal niveau, hoe valt dat in te richten? Wat zijn de consequenties als door vruchtwisseling de N-behoefte in grasland toeneemt en organische stof in bouwland opbouwt? Hoe zit het met ontijdige mineralisatie in het bouwland? In hoeverre conflicteert dit met de wens voor koolstofvastlegging? Hier kan aan gerekend worden.

12. Een verdere uitwerking van een lange-termijn adaptatiestrategie is voor melkveehouderijsysteem die meer rekening houdt met de risico's door klimaatverandering. Daarin moeten diverse vragen worden beantwoord zoals: Is intensivering of juist extensivering een manier om met klimaatverandering om te gaan? of is er voor beide richtingen ruimte onder klimaatverandering? Welke autonome ontwikkelingen vinden er in de melkveehouderij plaats? Is dit gunstig voor de adaptatie aan klimaatverandering of juist ongunstig? In hoeverre zijn verschillende adaptatiemaatregelen geschikt voor verschillende bedrijfssystemen (bijvoorbeeld m.b.t. locatie, bedrijfsgrootte, specialisatie, intensivering, multifunctioneel landgebruik).

13. Het verminderen van de afhankelijkheid en de prijsvorming op de wereldmarkt kan middels nieuwe teelten, nieuwe fermentatie of bioraffinage van lokale producten en reststromen tot geschikte voercomponenten. Ook nieuwe biobased teelten op reststromen kunnen een heel wenselijke aanvulling zijn voor de productie van eiwitten, oliën en hoogwaardige inhoudsstoffen (van der Weide, 2014 en 2016; Spruijt, 2014). Reststromen zoals deze bij de vergisting van mest beschikbaar zijn, kunnen ingezet worden voor de productie van algen, eendenkroos en andere waterplanten. Hierbij wordt per oppervlakte eenheid tot 4 á 5 keer zoveel eiwit geproduceerd. Bovendien bevatten sommige algensoorten waardevolle omega 3 en 6 vetzuren. Vervanging van een deel van het eiwit in het voer door algen, kan bovendien ook positieve effecten voor de gezondheid en de productkwaliteit opleveren. De teelten moeten echter nog verder geoptimaliseerd worden en de gewasbescherming moet nog grotendeels ontwikkeld worden.

Gewasbescherming Om te anticiperen op de ruwvoeder productie en haar gewasbescherming in het licht van klimaatverandering zou het wenselijk zijn om onderzoek te richten op:

1. Het verbeteren van de bodemkwaliteit en het vergroten van de biodiversiteit in tijd en ruimte door teeltmaatregelen zoals grondbewerking, bemesting en bodemadditieven, vruchtopvolging en meng- en dubbelteelten met vlinderbloemigen en ook agroforestry, inclusief de interactie met de gewasbescherming,

2. Ontwikkeling van teelt en de gewasbescherming in nieuwe en toekomstige teelten zoals aquatische planten en microalgen, voerbomen en -struiken, relatief nieuwe gewassen zoals sojabonen en sorghum en kort seizoen cultivars,

3. Het bepalen van de mogelijkheden van eventueel ingekruiste resistenties in voedergewassen op de beheersing van ziekten en plagen ook in akkerbouwplannen, waardoor de gewenste teeltruimte vergroot zou kunnen worden (ruwvoergewassen als ziektesaneerders in akkerbouwplan en de opbrengst naar de veehouderij),

4. Het bepalen van de mogelijkheden van gebruik reststromen, mestverwerking, sanitatie en toediening in de interactie met ziekten, plagen en onkruiden. 
Waterhuishouding

Overige thema's

adaptatie

\section{Onderwerp}

1. Onderzoek naar melkveehouderij met minimale klinische symptomen zou tegelijkertijd de risico's voor volksgezondheid mee moeten nemen.

2. Er is meer kennis nodig van de ecologie van dierziekten en de manier waarop ze overgedragen worden.

3. Het beperken van de impact van klimaatverandering op gezondheidsschade bij melkvee en mens vereist een systeembenadering, waarbij alle wetenschappelijke disciplines die relevant zijn zoveel mogelijk betrokken zijn en waarbij alle relevante systeemniveaus meegenomen worden.

4. Het verbeteren van bestaande oplossingen is een voor de hand liggende denkrichting, maar er moet ook aandacht zijn voor het ontwikkelen van nieuwe, betere oplossingen, zelfs als de structuur van de melkveehouderij hierdoor zou veranderen.

5. Een aandachtspunt binnen dit thema is de vleeskalverhouderij, waar het probleem van blootstelling aan vreemde ziektekiemen mogelijk nog groter wordt door klimaatverandering.

1. Water als productiefactor: Het kwantificeren van effecten van waterbeheer op de gewasproductie is lastig. Droogte, vernatting en verzilting veroorzaken verdampingsreductie en daardoor minder groei, maar er zijn onvoldoende veldexperimenten uitgevoerd waarin de relatie tussen verdampingsreductie en groeireductie onder veldomstandigheden specifiek onderzocht is. Wanneer deze effecten in meer detail bekend zijn kunnen de effecten van waterbeheer en klimaatverandering beter worden ingeschat.

1. In de huidige studie zijn alleen de thema's 'gras- en gewas productie' en 'plantaardige en dierlijke ziekten en plagen' uitgewerkt. Klimaatverandering kan echter ook gevolgen hebben voor prijzen van grondstoffen en zuivel, productiemiddelen (bijv. land, water, machines, gebouwen), en bedrijfsvoering (bijv. beweiding, timing maaien, voerregimes). Een ander thema dat in dit rapport niet expliciet naar voren kwam zijn de kansen en risico's op het gebied van fokkerij en genetica. Genetische selectie kan bijdragen aan lagere methaanemissies (zie Hoofdstuk 2 van dit rapport), maar ook aan robuustere rassen. In verband met de invloed van de selectierespons op andere niveaus is het van belang effecten van een dergelijke maatregel op verschillende systeemniveaus te onderzoeken. 

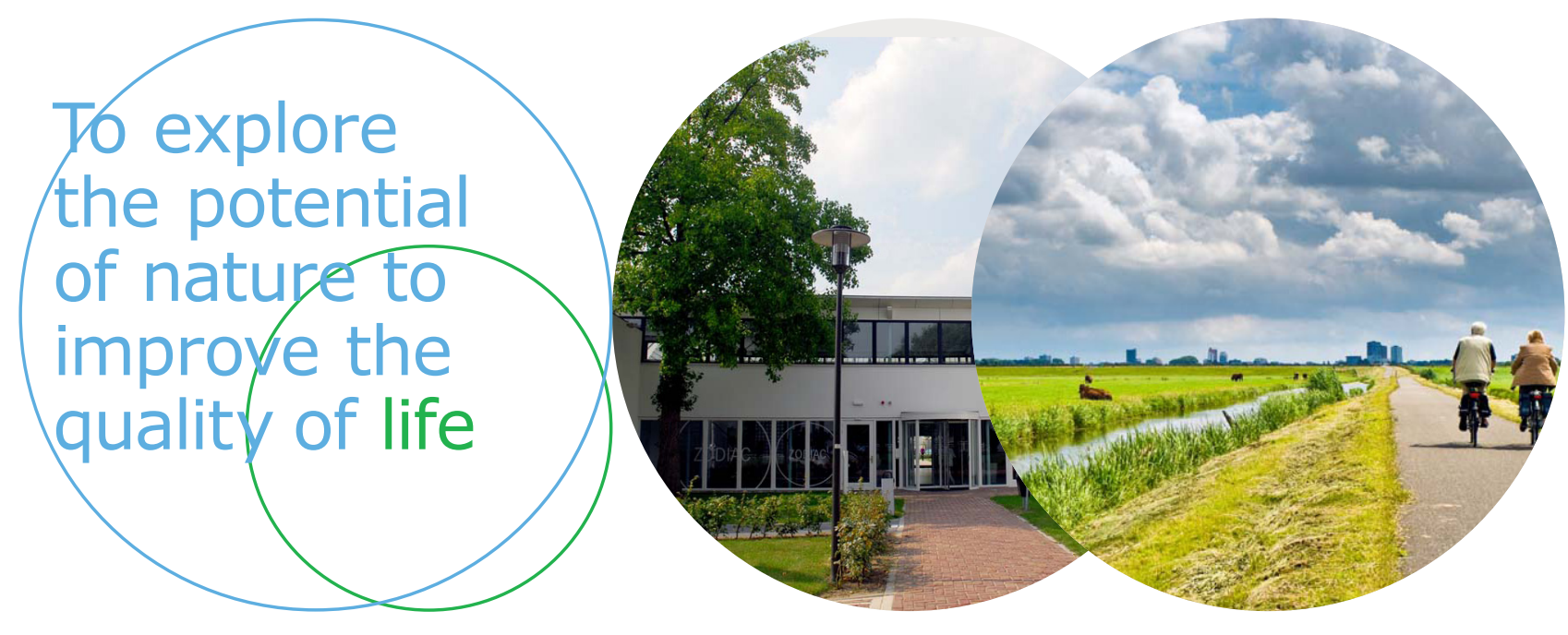

Wageningen Livestock Research Postbus 338

Wageningen Livestock Research ontwikkelt kennis voor een zorgvuldige en 6700 AH Wageningen

T 0317483953

renderende veehouderij, vertaalt deze naar praktijkgerichte oplossingen en innovaties, en zorgt voor doorstroming van deze kennis. Onze wetenschappelijke

E info.livestockresearch@wur.nl www.wur.nl/ livestock-research kennis op het gebied van veehouderijsystemen en van voeding, genetica, welzijn en milieu-impact van landbouwhuisdieren integreren we, samen met onze klanten, tot veehouderijconcepten voor de $21 \mathrm{e}$ eeuw.

De missie van Wageningen University \& Research is 'To explore the potential of nature to improve the quality of life'. Binnen Wageningen University \& Research bundelen 9 gespecialiseerde onderzoeksinstituten van Stichting Wageningen Research en Wageningen University hun krachten om bij te dragen aan de oplossing van belangrijke vragen in het domein van gezonde voeding en leefomgeving. Met ongeveer 30 vestigingen, 6.500 medewerkers en 10.000 studenten behoort Wageningen University \& Research wereldwijd tot de aansprekende kennisinstellingen binnen haar domein. De integrale benadering van de vraagstukken en de samenwerking tussen verschillende disciplines vormen het hart van de unieke Wageningen aanpak. 